\title{
Osmanlı Kudüs'üne Ait H. 1195/ M. 1781 Tarihli Keşif Defteri (Değerlendirme ve Transkripsiyon)
}

\section{The Price Estimate Register dated H 1195 / M. 1781 belonging to Ottoman Jerusalem (Evaluation and Transcription)}

\author{
Dr. Şerife EROĞLU MEMIŞ
}

\begin{abstract}
$\ddot{\mathbf{O} z}$
Çalışma, Kudüs-i Şerîf’te bulunan Mescid-i Aksa, Kubbetü’s-Sahra ve diğer mübarek mekânların tamire ihtiyaç duyan bölümlerinin keşif ve ölçümlerini içeren ve ehl-i vukûf olarak adlandırılan bilirkişilerce hazırlanan H. 1195/ M. 1781 tarihli keşif defterini konu edinmiştir. Deftere ilişkin bir değerlendirme sunmayı amaçlayan çalışmada, 18. yüzyılda Kudüs'te tamir ve bakıma ihtiyaç duyan mahallerin, kullanılan malzemenin, ölçü birimlerinin, fiyatların neler olduğu soruları da cevaplanmaya çalışılacaktır. $\mathrm{Bu}$ bağlamda çalışma üç bölümden oluşacaktır. Öncelikle Osmanlı tatbikinde vakıf mülklerin tamir ve bakımları konusu açıklanmaya çalışılacaktır. Sonrasında çalışma konusu olan Keşif Defteri şekil ve içerik bakımından incelenecektir. Üçüncü bölümde ise ulaşılan sonuçlara ilişkin bir değerlendirme yapılarak, defterde yer alan veriler tablo halinde sunulacaktır.
\end{abstract}

Anahtar Kelimeler: Keşif defteri, Kudüs, tamir, 18. Yüzyıl, Osmanlı Tarihi

Makale Türü: Araştırma

\begin{abstract}
The study covers the price estimate register dated 1195/1781 and was prepared by the experts in which the discoveries and measurements of the necessary parts of the Masjid al-Aqsa, Dome of the Rock and other blessed places in Jerusalem are included. In an effort to provide an assessment of the register, we will also try to answer the questions about the places, materials used, units of measure, prices in Jerusalem that need repair and care in the 18th century. In this context, the study consists of three parts. In the first part, repair and maintenance of waqf properties will tried to be explained in Ottoman applications. The price estimate register, which will be the subject of study afterwards, will be examined in terms of its form and content. In the third section, the exempted data recorded in the register will be evaluated and presented as a table.
\end{abstract}

Keywords: Estimate register, Jerusalem, repair, 18th century, Ottoman History

Paper Type: Research

${ }^{1}$ Vakıflar Genel Müdürlüğü, serife_eroglu@yahoo.com.

Atıf için (to cite): Eroğlu Memiş, Ş. (2019). Osmanlı Kudüs'üne Ait H. 1195/ M. 1781 Tarihli Keşif Defteri (Değerlendirme ve Transkripsiyon). Afyon Kocatepe Üniversitesi Sosyal Bilimler Dergisi, 21(3), 720-752. 


\title{
Giriş
}

\begin{abstract}
“ 'Izzetlü Mi'mâr Ağa; İ̧sbu defter-i keşfin muharrer mahal-i mübârekenin masârlfina imrâr-ı nazar ve ziyâdeleri var ise ana göre tahrîr ve i 'lâm eyleyesiz.

Sâdır olan emr-i 'âlî mûcibince Kudüs-i Şerîf'de vâki' Mescid-i Aksâ ve Sahratullahü'lMüşerrefe ve sâir emâkin-i mübârekelerin üzerlerine cânib-i şer 'i'den Kâtib-i sâni Şeyh Ali Efendi ve Nakîbü'l-Eşrâf ve me'zûn-ı bi'l-iftâ ve Şeyhü'l-Harem Efendiler ve sâir ehl-i vukûf ma 'rifetleri ve kalfa kulları ma 'rifetiyle yegân yegân keşif ve mesâha olunub işbu müfredât defteridir ki zikr olunur. Rebi 'u's-sânî sene 195.'
\end{abstract}

H. 1195/ M. 1781 tarihli Keşif Defteri müfredâtının² girizgâhından alınan yukarıdaki kayıtta Kudüs-i Şerîf'te bulunan Mescid-i Aksa, Kubbetü's-Sahra ve diğer mübarek mekânların tamire ihtiyaç duyulan bölümlerinin keşif ve ölçümlerini içeren ve ehl-i vukûf olarak adlandırılan, aralarında ikinci kâtib Şeyh Ali Efendi, Nakîbü'l-eșraf, Seyhü'l-harem Efendiler'in de bulunduğu bilirkişilerce hazırlanan bir keşif defteri olduğu kaydedilmiștir. Mimar Ağa'ya hitap edilerek, sunulan keşif defterinde belirtilen bedellerin incelenerek, fazla bir miktar yazılmış ise tespit edilmesi ve ona göre yazılarak karar verilmesi talep edilmiştir. Kalem kalem ölçümlere ve gerekli malzeme ile masraflara yer verilen bu defterde Mescid-i Aksâ, Sahratullahü'l-Müşerrefe camileri başta olmak üzere Harem-i Şerîf'te tamire ihtiyaç duyan mahaller ile Halilürrahman ve Nebi Üzeyr Makamları, Haseki Sultan İmareti, Nebî Davud, Nebî Musa, Nebî Yunus, Nebî İsa, Nebi Eşmovil Makamları ile Kamame Kilisesi yakınında bulunan Hazreti Ömer Cami-i Şerifi tamir edilmek üzere keşif yapılan başlıca yerler olarak kaydedilmiştir. ${ }^{3}$

5 varak ve yaklaşık 10 sayfadan ibaret ve Kudüs kentinden İstanbul'a gönderilen bu Keşif Defteri'nin son sayfasında keşfin H. 12 Rebiussani 1195/ M. 7 Nisan 1781 tarihinde Kudüs-i Şerîf Mahkemesi'nde muhafaza edilen sicile Kudüs Kadisı Nafiz Efendizade Abdulhamid tarafından kaydedildiği yazılmıştır. Bu tarihten yaklaşık iki ay sonra H. 5 Receb 1195/ M. 27 Haziran 1781 tarihinde ise, Mi ‘marân-1 Hâssa Mehmed Tahir tarafindan, Dîvân-1 Hümâyun'ca Bina Emîni olarak atanan Mehmed Hakkı Bey Efendi'ye bu işle görevlendirildiği bildirilmiş ve yapılacak olan tamirlere ilişkin belirlenen meblağın onaylandığını gösterir fermân-ı 'âlî talep edilmiştir. ${ }^{4}$

Osmanlı Dönemi'nde onarım ve restorasyon gibi imar faaliyetleri genellikle merkezden yürütülmekte idi. İhtiyaç duyulan yapım çalışmaları için merkezi yönetimden yani Dîvân-1 Hümâyun'dan onay alınması gerekiyordu. Merkezden onay almak için ise yapım ve onarım işinin tahmini maliyetinin keşif raporları şeklinde sunulması gerekmekte idi. Buna göre, malzeme eskimesine, iklimsel koşullara ya da bazı ilave ve tadilatlara dayalı olarak ortaya çıkan onarımlarda keşif yöntemi benimsenmiştir. Bahse konu keşiflerde, yapılacak tamir ve bakımlar yerinde tespit edilerek işçilik ve malzeme miktarları kalem kalem çıkartılır, bunlar piyasada geçerli olan rayiç fiyatlarla değerlendirilerek yaklaşık maliyet elde edilirdi. Yaklaşık maliyetin önceden bilinmesi ise yapılacak tamir ve bakımların planlanması, kontrol edilmesi ve onarım sonrası hesap verilebilirliğin teminine olanak sağlamakta idi. Onarımla ilgili yapı faaliyetlerinde ortaya çıkabilecek olası suistimallerin de önüne geçilmesi amaçlanmakta idi. Bunların yanı sıra onarımın gerektirdiği mali kaynakların nasıl ve kim tarafindan karşılanacağı hususları da yine bu keşifler yolu ile belirlenmekte idi. (Y1lmaz ve Dikmen, 2012: 73-83).

Yüzyıllar boyunca İslam toplumlarında ve devletlerinde önde gelen kurumlar arasında yer alan vakıflar sayesinde hayrî, sosyal, beledî, dinî ve eğitim alanlarında pek çok hizmet

\footnotetext{
${ }^{2}$ Ana muhasebe defteri, aslında mali yıl içinde tutulan ve daha teferruatlı kayıtlar içeren müfredât defterleri ile her türlü işleme ait temessük, hüccet, berat benzeri evrakın bir araya getirilerek ana muhasebe defteri düzenine aktarılması ile oluşmaktaydı. Bu müfredat defterleri arasında, maaş ödemelerinin kayıtlarını içeren defter-i vazîfehârân, imaretten yemek ve ekmek istihkakı olanların kayıtlarını tutan defter-i ta âmhârân ve defter-i fodulahârân, mukataa gelirlerinin hesaplarını içeren defter-i mukâta ât, tamirat harcamalarının dökümünü veren defter-i meremmât benzeri defterler bulunmaktaydı (Orbay, 2006).

${ }^{3}$ Detaylı bilgi için bkz. BOA, EV.HMH.d.6314: 1a-5b.

${ }^{4}$ Detaylı bilgi için bkz. BOA, EV.HMH.d.6314: 5b.
} 
yerine getirilmiştir (Ergenç, 1988: 667-683). ${ }^{5}$ Müslümanlar için Mekke ve Medine'den sonra üçüncü kutsal kent olan Kudüs'te de "Kadîm (Eski) Şehir" olarak adlandırılan tarihi bölgenin güneydoğusunda yer alan ve eski şehrin yaklaşık altıda birini kapsayan Mescid-i Aksâ6 ya da Harem-i Şerif olarak da adlandırılan alan kuruluşuyla birlikte Kudüs şehir merkezine hâkim olmuştur (Tanman, 2001: 516). Vakıf olarak kurulmamakla birlikte, zaman içerisinde şehir merkezini kuşatan ve idari sistem ve kentsel hizmetler örgütlenmesinin bir parçası olan geniş bir vakıf ağı ${ }^{7}$ nın da çekirdeğini oluşturmuşstur. Bu alan ve etrafında gelişen vakıflar, günlük hayatın her alanında kendini göstermiş̧ir. ${ }^{8}$ Vakıf kuran kimseler ise Harem-i Şerif ve yakın çevresinde namaz kılınması, Kur'an okunması, İslam fikhı çalışmalarının yanı sıra hacıların, tasavvuf dervişlerinin ve ulemânın ağırlanması gibi başlıca etkinlikleri kurmuş oldukları vakıflarla desteklemişlerdir. ${ }^{9}$

Emeviler Dönemi'nde inşa edilen başta Mescid-i Aksa ve Kubbetü's-Sahra camileri olmak üzere Harem-i Şerif ve çevresindeki yapılar, Abbasi, Fatımî, Eyyûbî ve Memlüklu dönemlerinde olduğu gibi ${ }^{10}$ Osmanlı döneminde de çok sayıda tamir ve bakımlarla ihya edilmiştir. ${ }^{11}$ Kentin manevî merkez noktasını oluşturan Harem-i Şerif alanı Osmanlı Dönemi'nde de öncelikli bir konuma sahipti. Zira Osmanlı klasik dönemi boyunca Kudüs’te inşa edilen ya da tamiri yapılan pek çok dini yapı Harem-i Şerif'te ya da yakın çevresinde yer almaktaydı. Ayrıca, Müslümanların kutsal mekânlarını korumak ve bakımını sağlamak Osmanlı Sultanı için de öncelikle dini bir vazife olarak düşünülmekte idi. Öte yandan, Osmanlı Dönemi'nde de Kudüs'te çokça yeni vakıf kurulmuş, ancak kentin siluetine büyük yapılar eklenmemiştir. ${ }^{12}$

\footnotetext{
${ }^{5}$ Vakıfların sosyal ve ekonomik hayat üzerindeki etkileri için bkz. (Yediyıldız, 2003). Yediyıldız’ın 18. yüzyıl için yaptığının bir benzerini 17. yüzyıla uyarlayan Hasan Yüksel'in bu yüzyılı temsil edebilecek bir örneklem seçerek (313 vakfiye) söz konusu vakıfları incelediği eserinin bir bölümü şehirlerin gelişiminde vakıfların rolüne ayrılmıştır (Yüksel, 1998). Yediyıldız ve Yüksel'in çalışmaları model alınarak yapılan çok sayıda çalışma da mevcuttur. Ö. Demirel'in Sivas şehri ve A. Gürbüz'ün Amasya örneğindeki çalışmaları yine bu kapsamda sayılabilir (Demirel, 2000; Gürbüz, 1993). Çalışmalarda; kent ve yöre bağlamında, vakıf eserlerle mahalleler arasındaki ilişkiden vakıf gelirlerinin kent ekonomisindeki yerine kadar vakıf kurumunun toplumsal ve ekonomik hayat üzerindeki etkileri, Osmanlı yönetim sistemi ve sosyal örgütlenmesi açısından sonuçları üzerinde durulur. S. Şavaş'ın çalışması, Osmanlı dönemi kentlerinde genel bir özellik olan zaviye çekirdeği üzerinde oluşmuş bir mahallenin gelişimini içerir (Savaş, 1992). Cafer Çiftçi'nin çalışması ise Bursa vakıflarının kentin gelişmesinde, sosyal ve iktisadi hayatındaki yeri açısından incelemiştir (Çiftçi, 2004).

${ }^{6}$ Kurşun kubbeli Mescid-i Aksâ Camii son zamanlarda Kıble Mescidi olarak anılmaktadır. Mucireddin, Mescid-i Aksâ'yı yalnızca Emevîlerce yapılan Mescid-i Aksâ Câmii ya da Kıble Mescidi olarak da anılan Cami olarak değil, fakat bütün bir kapalı külliye olarak tanımlamıştır. Bu tanımlama ile Harem-i Şerif olarak da anılan alanda yer alan diğer dinî yapılar da kastedilmiştir (ElHanbelî, 1973/2: 11, 24.) Ancak biz çalışmamızda Osmanlı Dönemi belgelerinde yer aldı̆̆ şekliyle kurşun kubbeli camiyi Mescid-i Aksâ Camii ve alanı da Harem-i Şerif olarak kullandık.

7"Vakıf ağı" kavramı Ömer Lütfi Barkan tarafindan "hayrât siteleri" ve Bahaeddin Yediyıldız tarafından "vakıf hayrât sistemi" kavramlarına alternatif bir kavram olarak sunulmuştur. 20. yüzyıla ait bu kavram ile kökleri İslâmiyetin ilk yıllarına uzanan vakıf kurumunu anlama çabası etrafında şekillenen çalışma ile sur içerisinde kalan "Kadim kent”teki vakıfların kent mekânına, toplumsal ilișkilere ve merkezi hükümetle olan ilişkilere etkileri vakıflar perspektifinden ele alınmıștır. Bkz. (Eroğlu Memiş, 2016).

${ }^{8}$ Detaylı inceleme için bkz. (el-Hanbelî, 1973; el-'Arif, 1961; el-Aseli, 2002: 334-338; el-Aseli, 1989: 200-224; Tibawi, 1978; Tütüncü, 2006; Eroğlu Memiş, 2017b).

${ }^{9}$ Bahse konu vakıflar ve sunulan hizmetlere ilişkin detaylı bir inceleme için bkz. (Eroğlu Memiş, 2016: 77-151).

${ }^{10}$ Özellikle Kubbetü's-Sahra'nın tarihinin daha önceki evreleri, çok sayıda araştırmacı tarafından kapsamlı bir şekilde araştırılmış ve yayınlanmıstır. Bunlar arasından Max van Berchem ve Oleg Grabar'ın calısmaları zikredilmelidir. (Grabar, 1959: 33-62; a.g.y., 1973: 48-67; Berchem, 1927). Öte yandan, Myriam Rosen-Ayalon ve Michael Burgoyne, Harem'in planının ve süslemelerinin önemini ele almış ve Kudüs'ün mimari tarihini Mamluk dönemine kadar incelemişlerdir (Rosen-Ayalon, 1989; Burgoyne 1986).

${ }^{11}$ Örn. bkz. (Aslanapa, 1989: 15-18; Cuneo, 2000: 211-221; Vesika ve Fotoğraflarla, 2009; el-Aseli, 2000: 200-202; Cuneo, 2000 : 211-221). St. Laurent ve Rieldmayer tarafindan kaleme alınan çalışmada, Osmanlı'nın yalnızca fetih ve sonrasında Kanuni Sultan Süleyman Dönemi’nde değil, Kudüs’teki sonraki yüzyıllarda da imar ve ihya faaliyetlerine devam ettiği, 18. ve 19. yüzyıllarda Kudüs'ün, Kubbetü's-Sahra ve Harem-i Şerif' in aktif koruyucuları olduğu belirtilmiştir. (Laurent ve Riedlmayer, 1993: 76). Yakın zamanda Köse tarafından kaleme alınan "Osmanlı Dönemi Kudüs'ünde Mimari Çalıșmaları” başılıkı çalışmada; surların yeniden inşası, Kubbetü's-Sahra'nın ve Mescid-i Aksa'nın onarımı, su hatlarının yenilenmesi ve onarımı, dini mimari, sivil ve askeri mimari alanda yapılan çalışmalar başlıkları altında Osmanlı Dönemi’nde yapılan tamir ve imar faaliyetlerine dair detaylı bilgiler sunulmuștur (Köse, 2017: 27-47).

${ }^{12}$ Kudüs kenti geneli için de söylenebilecek bu durumun, Hillenbrand'a göre gerekçesi Harem ve çevresinin Memluk yapılarıyla sıkı sıkıya kuşatılmış olması ve Osmanlı mimarisinin özelliklerini yansıtacak büyük ölçekli yapılar için uygun boş bir alanın bulunmamasıdır (Hillenbrand 2000: 7). Avcı'ya göre ise, Mekke ve Medine örneklerinde görüldüğü üzere, Osmanlı yapılarının küçüklüğü, kentin siluetine hâkim olan Kubbetü's-Sahra'nın yüksekliğini geçmemek gibi, dini saygıdan kaynaklanan bir tutuma da bağlı olabilir (Avc1, 2004: 36).
} 
Kudüs Harem-i Şerif’i ile mahallelerine dağılmış durumda olan bahse konu yapılar, zamanla "şiddet-i rüzgâr", gibi tabiat olayları, "ihrâk-ı azîm", savaş gibi doğal etkenlerin yanı sıra insan faktöründen kaynaklanan kasit ve ihmaller nedeni ile müteaddit defalar tamir, bakım ve onarıma ihtiyaç duymakta idiler. ${ }^{13}$ Bazı arşiv belgelerinde ise gerekçe gösterilmeden, vakıf eserlerinin "harâbe müşrif" olarak yıkılmaya yüz tuttuğu, bazılarında da bu durum "der-i eyyâmla harâb ve mâil-i türâb" veya "mürur-ı eyyâm", "mürur-l ezmine" gibi ifadelerle zamanın ve günlerin geçmesine bağlanmaktadır (Hızlı, 1993: 219-232).

Bunlar gibi çeşitli gerekçelerle, Kudüs’te tamir ve bakıma ihtiyaç duyan mahallerin keşif ve ölçümlerini içeren 1195/ M. 1781 tarihli keşif defterini incelemeyi amaçlayan mevcut çalışma üç bölümden oluşmaktadır. Öncelikle Osmanlı tatbikinde vakıf mülklerin tamir ve bakımları konusu açıklanmaya çalışılacaktır. Sonrasında çalışma konusu olan Keşif Defteri şekil ve içerik bakımından incelenecektir. Üçüncü bölümde ise elden edilen sonuçlar değerlendirilerek, defterde yer alan veriler tablo halinde sunulacaktır.

\section{Osmanlılarda Yapıların Tamir ve İhyâsı}

Genel bir yaklaşım içerisinde Osmanlılar öncelikle, şehirlerinde mevcut eserleri korumayı hedeflemişler, bunun için de harap hale gelen yapıların tamir ve ihya çalışmaları ile tekrar eski fonksiyonlarını kazandırmaya çalışmışlardır. Bununla birlikte, Osmanlılar kendi dönemlerinde yapılan mimari eserlerin onarımlarına da büyük önem vermişlerdir. Böylece bu yapılarda verilen hizmetlerin sürekliliği sağlanmış ve gelecek nesillere de sağlam bir şekilde intikal ettirilmiştir (Dündar, 2001: 269).

Osmanlı döneminde merkezden yönetilen imar işlemlerinin başlayabilmesi, onarıma muhtaç eserin Divân-1 Hümâyûn'a bildirilmesine bağlı idi. Süreçte öncelikle tamire ciddi şekilde ihtiyaç duyulan yapının mütevellisi, bazen müderris ve "sâir mürtezika"sı mahkemeye gelerek, binalarının "müşâhede olunmasını" talep etmekte idiler. Çok sayıdaki arşiv belgelerinden, eserlerin tamirleri için kadıların, diğer idarecilerin, vakıf yöneticilerinin, şahısların ve halkın müracaat ettikleri anlaşılmaktadır (Dündar, 2001: 272). Şahıslar, doğrudan Dîvân-1 Hümâyun'a başvurabildikleri gibi, isteklerini mahalli kadılara da bildirmişlerdir. Dîvân1 Hümâyun, resmi görevlilerin dışında gelen, tamir isteklerini yörenin kadılarına havale ederek, onarımı ve yeniden yapılması istenilen yapılar hakkında çoğu zaman bilgi istemiştir. Böylece bir ön araştırma süreci başlatılmakta idi.

Ön inceleme neticesinde ise, tamirine onay verilen eserler hakkında ferman çıarılarak durum mimar ağaya bir yazı ile bildirilmekte ve başka bir yazı ile de defterdara havale edilmekte idi. Bu yazı üzerine mimar ağa, tamiri yapılacak eserin keşfine katılmak ve restorasyon çizimini yapmak üzere hassa mimarlarından uygun gördüklerini saraya önerirlerdi. ${ }^{14}$ Bunun üzerine Dîvân-1 Hümâyun'dan ilgili hassa mimarına tamire ihtiyaç duyan binaların tespit edilmesi ve gerekli tamirat masraflarının keşfedilerek defterlere kaydedilmesi ve bu defterlerin de Saray'a bildirilmesi görevinin tevdi edildiği bir yazı ile bildirilirdi. Bu arada, saray tarafından, tamir işlemlerini yürütecek ve her türlü alım satımı yapabilecek ayrıca bu konularda deneyimli bir bina emini tespit edilerek görevlendirilirdi. Kadılara da birer yazı yazılarak, hassa mimarı ve görevlendirilen kişiyle birlikte tamir edilmesi gereken eserin keşfini yapıp İstanbul'a keşif defterini göndermesi istenirdi (Dündar, 2001: 272-273).

Kadı ise bunun üzerine; nâib ve diğer bir görevlinin yanı sıra "hassa mi 'marlar" ve "ehl-i hibre üstâdlar", "ehl-i vukûf kimesneler" ile bina işlerinden anlayan "bî-garaz Müslümanlar"dan oluşan bir heyete görev vermekteydi. Tamir işlemlerini yürütecek bütün görevliler bu şekilde belirlenerek, ilgili mimarın, bina emininin, kadının veya kadılıkça görevlendirilen birinin ve belgelerde ehl-i vuk̂ff olarak tarif edilen mimarlık işlerinde deneyimli

\footnotetext{
${ }^{13}$ Vakıf eserlerinin tamiri ve bakımı konusunda detaylı bilgi için bkz. (Barkan, 1963: 14; Akgündüz, 1994: 115-122; Çetin, 2000: 62-63; Gabriel, 1938; Erdoğan, 1968: 149-205; Dündar, 2001: 269-280; Bakırer; 1973: 113-126; Hıl1, 1993: 219-232).

${ }^{14}$ İstanbul'daki Hassa Mimarlar Teşkilatı teknik işleri yürüten ve keşifleri yapacak mimarları belirleyip Dîvân-1 Hümâyun'a teklifte bulunan önemli bir kurumdu. (Dündar, 1999: 9-37).
} 
yöre halkından kişilerin de katılımlarıyla oluşturulan bir heyet tarafından tamiri yapılacak eserin keşfi yapılırdı. Bu heyet, tamir görecek olan yapıya gelerek, binanın hangi yerlerinin onarıma muhtaç olduğunu, ne tür malzemelerin kullanılacağını, malzeme miktarı ve fiyatlarını, ne kadar usta, neccar, 1rgat vs. ile yapılacağını, bunların toplam ücretlerini ve tamiratın genel yekûnunu içeren bir rapor hazırlayarak mahkemenin görüşüne sunardı. Bu rapor doğrultusunda mahkeme, 'Âsitâne-i Sa 'âdet'e onay almak üzere başvururdu.

Keşif defterleri adı altında kaydedilen bu raporlar üç kısımda hazırlanmakta idi (Serin, 2016). Tahmini maliyetlerin kaydedildiği ilk defter "Keşf-i evvel" defteri adıyla kayıt altına alınırdı. Bir keşf-i evvel defteri niteliği taşıyan ve çalışma konusunu oluşturan bu defter de Kudüs kadısı tarafından görevlendirilen heyet tarafından hazırlanarak İstanbul'a gönderilmiştir. Keşif Defteri Hassa Mimarlarından Mehmed Tahir tarafından Dîvân-1 Hümâyûn'a sunulmuş ve bahse konu keşif doğrultusunda tamir ve bina işlerini mahallinden takip etmek üzere Dîvân-1 Hümâyun hâceganlarından Mehmed Hakkı Bey Efendi'nin görevlendirilmesine ilişkin ferman talep edilmiştir (BOA, EV.HMH.d. 6314, 5b.)

Sürecin devamında ise, yapılacak işlerle ilgili mali kaynaklar ile maliyet hesapları, ilk keşifte bulunmayan veya sonradan eklenen kısımlar ile ilgili işler "Keşf-i sâni" defterlerine kaydedilirdi. İmalat veya tamiratlar yapıldıktan sonra da eksik veya yapılamayan işlerle ilgili gerektiğinde "Keşffi sâlis" defterleri hazırlanırdı (Serin, 2016). Bu son kontrolle birlikte, binaların kullanıma hazır hale gelip gelmediği ve onarımın usulüne uygun gerçekleşip gerçekleşmediği mahkemeye rapor edilmekteydi (Hızlı, 1993: 220-221). Keşif ve muayeneleri bilirkişiler (ehl-i vukûf) ile konuyla irtibatı olan birçok kişi tarafından yapılan vakıf eserlerinin tamirleri, yine çok sayıda şahidin takip ettiği bir oturumda kayıtlara geçirilerek resmen tescil edilmekteydi. Tamir belgeleri zapta geçirilirken vakıf eserleri tek tek ele alınarak harcama kalemleri gösterilmekteydi (Hızl, 1993: 220-221).

Burada detaylı bir şekilde anlatılan vakıf eserlerin tamirine yönelik sürecin Osmanlı Kudüs'ünde tatbikini H. 1195/ M. 1781 tarihli "Keşf-î evvel" defterinden takip edebilmek mümkündür. Kentin manevî merkez noktasını oluşturan Harem-i Şerif alanının, Osmanlı Dönemi'nde de öncelikli bir konuma sahip olduğunu defterde 162 kalemde zikredilen ve Kubbetü's-Sahra ve Mescid-i Aksa camilerine ait kayıtlar başta olmak üzere Harem-i Şerif alanında bulunan tamire ihtiyaç duyulan mahallerin kayıtlarından da takip etmek mümkün olabilmiştir. Harcamalar arasında Sahratullahü'l-Müşerrefe içerisinde bulunan büyük mihrab ve minberlerin tamiri ve yenilenmesi, Harem-i Şerif'te Bâb-1 Mahkeme ve Bâb-1 Cennet gibi kapıların yenilenmesi, Kubbetü'l-Ervâh, Kubbetü'l-Ahmar gibi kubbelerin sıvalarının yenilenmesi, Mescid-i Aksâ içerisinde bulunan büyük mihrabın, mahfelin boyanması, yenilenmesi, Nebi Davud Mihrabı ve kubbelerinin sıvasının yenilenmesi, Hanbelî, Mâlikî camii şeriflerinin sıvalarının yenilenmesi, Burak halkası ve mescidinin sıvasının yenilenmesi, Kadı kubbesinin, Fârisiyye Medresesi'nin sıvasının yenilenmesi, Kayıt Bay Cami-i Şerîfi ve sebilinde çeşitli yenilemeler, Osmâniyye Medresesi'nin sıvasının yenilenmesi, Sebil-i Şağlan ile Nebi Süleyman kubbesinin ve kürsüsünün sıvasının tecdidi, Sitti Meryem mihrabı, Fahriyye Cami-i Şerifi sıvalarının yenilenmesi, Meryem Kapısı ve Halil Kapısı sıvalarının yenilenmesi yer almıştır. Bu örneklerde de görüldüğü üzere, hayrî-kamusal vakıflar olarak addedilen ve yönetim ve denetimleri ile her türlü tamir ve bakımları merkezî hükümetçe yürütülen Mescid-i Aksa, Kubbetü's-Sahra, Meğaribe Camii, Fahriyye Medresesi, Hangâhı gibi vakıf hayrâtlarının tamir ve bakımlarına ilişkin detaylar keşif defterlerine kaydedilmekte idi.

Harem-i Şerif alanı yakınında bulunan Haseki Sultan İmareti'ne ilişkin tamir ve bakımlar arasında imaretin fırını, kileri ve ambarına ilişkin detaylı tanımlamalara yer verilmiştir. Osmanlı sultanının hayırseverliğinin bir göstergesi ve aynı zamanda da güç ve meşruiyetinin kaynağı olan imaret yalnızca Kudüs için değil etrafı için de çok önemli bir fonksiyonu yerine getirmekte idi (Singer, 2004; Ze'evi, 2000: 4-5). Dolayısıyla Osmanlı yönetimi boyunca yapılan çok sayıda tamir ve bakımlar imaretin yüzyıllarca hizmetlerine devam etmesine vesile 
olmuştur. ${ }^{15}$ Zira surlarla çevrili kadîm kentte Haseki Sultan İmareti ya da et-Takiyye diye bilinen görkemli bina hâlâ ayaktadır (Singer, 2004: 1).

İki büyük kutsal kent olan Mekke ve Medine’ye verilen "Haremeyn-i Şerifeyn” adının bir yansıması olarak Kudüs ve el-Halil kentlerine de "el-Haremeyn" denirdi. El-Halil şehrinin hac yolları üzerinde bulunması ve burada bulunan peygamber kabirleri nedeniyle y1l boyunca şehre, dünyanın dört bir tarafından çok sayıda ziyaretçi gelmekte idi. Bu ziyaretçiler Haremü'lHalil'de ağırlanır ve burada onlara Halil İbrahim Sofrası (Simâtü'l-Halil)'de "men" adı verilen bir ekmek ve zeytin ile çorbadan oluşan ve "es-simâtüll-Halîlî, simât-l şerif, el-adesü'l- Halîlî", adlarıyla bilinen bir yemek ikram edilirdi (Uluçam, 1997: 308). El-Halil'de bulunan peygamber ve eşlerinin kabirleri ile Simâtü'l-Halil'in tamiri defterde başlica tamir gerektiren mahaller olarak kaydedilmiştir.

Makam-1 Halîl'in yanı sıra Nebi Üzeyr, Nebî Davud, Nebî Musa, Nebî Yunus, Nebî İsa, Nebi Eşmovil Makamlarına yapılan keşiflerde makam, duvar, mihrab ve kubbeleri başlıca tamir alanları olarak kaydedilmiştir. Kamame Kilisesi yakınında bulunan Hazreti Ömer Cami-i Şerifi tamir edilmek üzere keşif yapılan başlıca yerler olarak yazılmıştır.

Öte yandan, "evkâf-ı mülhakadan" olarak addedilen ve örneğin vakfiye şartı gereği Meğaribe Mahallesi şeyhi tarafindan yönetilen Ebu Medyen el-Ğavs Vakfi gibi mülhak vakıflarda bu sürecin mütevellinin inisiyatifine bağlı olarak zaman zaman ihmal edildiği de olmuştur. Kudüs'te görev yapan kadı veya kadı nâibinin de bilgi sahibi olduğu bu durumlardan, çoğu zaman Dîvân-1 Hümâyun'a gönderilen arzuhâl ve arz-ı mahzâr olarak adlandırılan kişisel ve toplu şikâyet dilekçeleri sayesinde haberdar olunmakta idi. ${ }^{16} \mathrm{Bu}$ minvalde gönderilen kayıtlarda mütevellinin ihmali nedeniyle vakfın musakkafâtının "harâb ve mâil-i sükût oldukları" ve yıkılmaya yüz tuttuğu haber verilmektedir. ${ }^{17}$

\section{H. 1195/ M. 1781 Tarihli Keşif Defteri’nin Şekil ve Muhteva Özellikleri}

Keşif Defteri Kudüs Harem-i Şerifi içerisinde yer alan ve tamire ihtiyaç duyan mahalleri detaylı bir şekilde, yapı ve tamir malzemelerinin de özelliklerini belirterek tanımlamıştır. Örneğin, defterde yer alan bir tanımlama şöyle kaydedilmiştir: "Sahratullahi mübârekenin bâlâsında pirinç tel örmeli ve çarçubeli kafes tecdîdi." (BOA, EV.HMH.d. 6314, 1a). Bu tanımlamadan, Kubbetü's-Sahra olarak da adlandırılan Sahratullah'ın üstünde bulunan pirinç tel örmeli ve çerçeveli kafesin yenilenmesi tamir edilecek mahal olarak kaydedilmiştir.

Bazı kayıtlarda da; “Kubbetü'l-ervah ve Kubbetü'l-erbah ve Kubbetü'l-ahmar derunlarında horasanlı kanatlı beyaz slva tecdîdi. Terbi'an $150 x$ fi 75= 11250." örneğinde olduğu gibi tamire ihtiyaç duyan birkaç yapı aynı kayıtta zikredilmiştir (BOA, EV.HMH.d. $6314,1 b)$.

Defterde, vakıf binalardaki tamiratlarda kullanılan malzemenin çeşidi ve miktarı da detaylı bir şekilde yazılmıştır (Bakırer, 1973: 125). Örneğin: "Sahratullahü'l-müşerrefenin hedm olunan bab-l garbda sûm ruhâm sıvalı ve kavsli ve rumi aşkımalı ve altun âyet-i kerîmeli ve sultan tarihli timur zevaneli ve kurşun akıtmalı slva ve kavs tecdîdi. Arzan mesâhâ 4. Kadden mesâhâ 7. Terbî'an $28 \times$ fi 2160=60480." (BOA, EV.HMH.d. 6314, 1a). Burada da tamir

\footnotetext{
15“Surlarla çevrili eski şehrin merkezinde, 'Vâd ile Akabetü't-Takiye caddelerinin birleştiği noktada, Via Dolorosa [Çile Yolu]'nun biraz güneyindeki tepeye çıkan yokuştan, Haseki Sultan Imareti ya da et-Takiyye diye bilinen görkemli bina hâlâ ayaktadır." (Singer, 2004: 1).

${ }^{16}$ Arzuhâl, 'askerî sınıftan ya da re'âyâ'dan, Müslim veya zimmî kesimden herkesin bir dilek veya şikâyet bildirmek için alt makamdan üst makama yazabildiği bir tür dilekçedir. Bununla beraber genellikle, askerî sınıfın sunduğu dilekçelere sadece arz, reaya'nın sunduklarına ise arzuhâl denirdi (İnalcık, 1998: 50-51). Sikâyet edenler tek kişi olabileceği gibi bir topluluk hatta vakıf gibi bir kurum da olabilirdi. Şikâyet konusu bazen mahkemenin verdiği bir kararı tanımama ve eşkıya zulmünden bunalma, örf mensuplarının haksız davranışları olabileceği gibi, köylü ile tımarlı sipahi arsındaki vergi anlaşmazlığı veya nizamnamelere uymayan esnaf da arzuhâllere konu teşkil ederdi (Gündoğdu, 2009).

${ }^{17}$ Örneğin bkz. Muessesetu İhyâu't-Turâs ve'l-Buhûsu'l-İslamiyye Arşivi, Kutu No:6, Dosya No: 13/1327/18/0/2/3, s. 4/A; Kutu No:6, Dosya No: 13/1327/18/0/2/3, s. 4/B.
} 
edilecek mahal ve kullanılacak malzeme detaylı bir şekilde tanımlanmış, malzemenin ölçüleri ve toplam masraf da hesaplanılarak kaydedilmiştir.

Defterde yer alan ölçü birimleri arasında tamire ihtiyaç duyan mahallerin yapı ve tamir malzemeleri detaylı bir şekilde tanımlandıktan sonra, malzemelere ilişkin ölçüler ve bu ölçülere göre hesaplanmış yaklaşı maliyet de kuruş ve para cinsinden kaydedilmiştir. Ölçü birimlerinde boyuna (tûlen mesâhâ), enine (arzen mesâha), uzunluğu (kadden mesâha) gibi ölçü birimleri ile ifade edilen malzemeler, terbî 'an (kare) ile ifade edilen kısımlarla fiyatlandırılmıştır.

Dokuz ayrı bölüm ve ayrı başlıklar halinde kaydedilen keşif bedellerinin, her bir bölümünün sonunda genel toplam (cem 'ân yekûn) başlı̆̆1 altında masraflar toplanmıştır. Yukarıda da ifade edildiği üzere defterdeki en fazla harcama kalemi ve tamire ihtiyaç duyulan mahal Kubbetü's-Sahra ve Mescid-i Aksa camilerini de içine alan Harem-i Şerif alanına dair keşif mahal ve bedellerinin yer aldığı birinci bölümdür. İkinci bölümde, Hazreti Halilurrahman Makamı'nda yapılacak tamir ve ihya faaliyetleri 61 kalemde kaydedilmişken; bu sayı Üzeyr Peygamber Makamı'nda 27; Davud Peygamber Makamı'nda 7; Musa Peygamber Makamı'nda 8; Yunus Peygamber Makamı'nda 4; İsa Peygamber Makamı'nda 8; Eşmovil Peygamber Makamı'nda 4; Kamame Kilisesi yakınında bulunan Hazreti Ömer Cami-i Şerifi'nde 3'tür. Haseki Sultan İmareti'nin tamir ve bakıma ihtiyaç duyan mahalleri de ayrı bir başlık altında 33 kalemde kaydedilmiştir. Şüphesiz ki, Kubbetü's-Sahra, Mescid-i Aksâ ve Hazreti Ömer gibi camilerin tamir ve bakımları Osmanlı'nın Kudüs'teki hâmîliğini görünür kılmakta ve Peygamberlerin Makam'larının tamir ve bakımları da bu duruma olumlu katkılar sağlamakta idi.

Defterin detaylı bir şekilde incelenmesi ile binalardaki aksaklıkların en çok nerelerde meydana geldiği ve bu aksaklıkları gidermek, yapıyı sağlamlaştırmak için ne gibi tedbirler alındığı hususlarına açıklık getirilebilir. Çalışmada Ek 1'de yer verilen Tablo'da da görüldüğü gibi en çok üzerinde durulan yapıların sıvalarının yenilenmesi ve kubbe kurşunlarının tamiridir. Muhtemelen kullanma ve eskimeye bağlı olarak yapıların sıvalarının, rüzgâr ve firtına sebepleriyle kubbe kurşunları devamlı bakım icap ettirmekteydi. Bunların yanı sıra duvar, sıva, cam, pencere çerçevesi ve kapı tamiratlarının ise ikinci derecede geldiği görülmektedir.

Öte yandan, defterde nakil ücretleri hakkında herhangi bir bilgiye rastlanılamamıştır. Bu da, malzemenin mahalli olarak temin edildiği düşüncesini akla getirmektedir. Malzeme fiyatlarına taşıma ücretlerinin ilave edilmemesi de yine malzemelerin başka yerlerden getirilmediği düşüncesini öne çıkarmaktadır. Defterde hakkında bilgi verilmeyen bir diğer husus ise iş̧̧i ücretleridir. ${ }^{18}$ Mevcut defterin bir keşf-i evvel defteri olma niteliği dikkate alındığında, bu defteri müteakip malzeme temini, işçiler ve görevlilere ilişkin diğer keşif defterlerinin olma ihtimali oldukça yüksektir.

\section{Değerlendirme}

Tarih boyunca Kudüs kenti, Halep gibi bir ticaret merkezi ya da Kahire ve Şam gibi büyük bir ekonomik merkez değildi. Ticari ve ekonomik olarak bu şehirlerin gölgesinde kalan kent, semavi dinler açısından kutsallığın merkezi olarak öne çıkmakta idi (Avcı, 2004: 22-23; 31-32). Osmanlı yönetimi döneminde de özellikle İslam'ın ilk kıblesi, ikinci haremi ve üçüncü mescidi olması, Hz. Peygamberin İsrâ ve Mi'râc hadiselerinin gerçekleştiği yer olması bakımlarından Kubbetü's-Sahra ve Mescid-i Aksa camilerini içine alan Harem-i Şerif alanına ve kente büyük önem atfedildi. Ve bu, Osmanlı yönetiminin başlamasından hemen sonra bir dizi mimari ve altyapı çalışmalarında kendisini göstermiştir. Öte yandan, Memluk dönemiyle

\footnotetext{
${ }^{18}$ Sevinç tarafindan kaleme alınan ve Mescid-i Aksâ ile Kubbetü’s-Sahrâ Camilerinde 1720 ve 1742 yıllarına ait imar ve tamir faaliyetlerini konu alan çalışmada; camilerin tamirleri için temin edilecek çoğu durumda da satın alınacak kereste ve diğer malzemelerin cinsi, sayısı, birim fiyatı ve toplam tutarları tablolar halinde sunulmuştur. (Sevinç, 2016: 117-121) Malzemelerden kerestenin İstanbul, İzmir ve İznikmid'den temin edildiği, diğer malzemelerin ise Donanmayı Hümâyûn kalyonlarından biri ile Yafa İskelesine gönderileceği, oradan da Kudüs, Gazze ve Nablus mütesellimleri ile Kudüs ve Yafa kadıları, Yafa Kalesi dizdarları ve ağaları ile ayan ve vilâyet işerlerinin karayolu ile Kudüs'e ulaştıracakları belirtilmiştir (Sevinç, 2016: 121). Yine inşaatta ve tamirde istihdam edilecek görevliler ve ücretleri de ayrı başlıklar altında incelenmiştir. (Sevinç, 2016: 129-133).
} 
karşılaştırıldığında, Osmanlı yönetiminin kentteki önceliklerini değiştirdiği görülmüştür (Avc1, 2004: 39). Kentte yeterli sayıda mevcut olan dinî ve eğitim yapıları yerine, Osmanlı yönetimi kentin altyapısına yatırımlar yapmış, sosyal ve beledi hizmetlere ağırlık vermiştir. Faaliyetlerini güvenlik koşullarının düzeltilmesi, su sağlanması, yeni bir kapalı çarşı kurulması ve Kudüs halkının refahının artırılması gibi alanlarda yoğunlaştırmıştır (Raymond, 1979-1980: 84-101). Fetihten yaklaşık yirmi yıl sonra (1537 ve 1542 yılları arasında) kent surlarının ve kalesinin yeniden inşası, kentteki güvenlik duygusunu artırmıştır (St. Laurent - Riedlmayer, 1993: 77; Hillenbrand, 2000: 19-32). Su şebekesinin onarılması ve genişletilmesi, bu arada Beytüllahim'in güneyindeki Artas köyünden Kudüs'e boru hattı döşenmesi, hızla büyüyen kente su sağlanmasına yardımcı olmuştur. Şehir sakinlerinin temiz su ihtiyacının karşılanması için beş tanesi Harem-i Şerif içinde bir tanesi yine Harem etrafında olmak üzere toplam altı çeşme yapılmıştır (Rosen-Ayalon, 1989: 589-607). Yine bu çerçevede, şehrin su ikmal sistemi için rezervuar vazifesi görmek ve Kudüs'e gelen hac kervanlarına ve yolculara su sağlamak maksadıyla, sur dışındaki Sultan Havuzu'nun aşağı kısmında büyük bir su deposu inşa edilmiştir (Cohen, 1989: 4-5). Bu temel ihtiyaçların teminine yönelik yapılan çalışmaların yanı sıra, örneğin on altınc1 yüzyılın ortalarında, Sultan Süleyman, Harem-i Şerif'te bulunan Kubbetü's-Sahra'nın dış yüzeylerini çini ile kaplattırmıştır. Bu çiniler sonraki yüzyıllarda Osmanlılar ve diğerleri tarafından defalarca restore edilmiştir. ${ }^{19}$

Öte yandan, Osmanlı yönetimi yalnızca fetih sonrası Kanuni Sultan Süleyman döneminde değil, idaresi dönemindeki sonraki yüzyıllarda da imar ve ihya faaliyetlerine devam etmiştir (St. Laurent - Riedlmayer, 1993: 76). 17. yüzy1lda kentte mevcut büyük anıtsal yapılara birkaç ilave ve onarım yapılmıştır. Sebîl Şa'lân olarak bilinen Harem-i Şerîf içindeki Memlük dönemine ait çeşme 1627 y1lında onarılmıştır. 1685 yılında ise Hacı Mustafa oğlu Hacı Abdulkerim Çorbacı tarafından Kudüs'te vakfedilen ve "Çorbacı Sebili" olarak bilinen sebil inşa ettirilmiştir (el-Aseli, 1989: 212). ${ }^{20}$ Kudüs'e su temini için kurulan Kanâtü's-Sebîl de 16561666 yılları arasında tamir edilmiştir. Harem-i Şerif'te bulunan Câmi-i Hanâbile de 1611 yılında restore edilmiştir. El-Aseli, Kudüs bölgesinde 17. yüzyılda inşa edilen en büyük tek yapının Beytüllahim yakınlarında Sultan II. Murad tarafından yapılan kale olabileceğini belirtmiştir (elAseli, 1989: 212).

17. yüzyılda da daha önceki dönemlerde olduğu gibi en önemli onarımlar yine Harem-i Şerif’te yapılmıştır. Bu dönemde Sultan III. Mehmed (1597), Sultan I. Mehmed (1603) ve Sultan I. Mustafa (1617) tarafından Kubbetü's-Sahra yenilenmiştir (el-Aseli, 1989: 212).

18. yüzyılda Kubbetü's-Sahra ve Mescid-i Aksa için en az dört restorasyon döneminin olduğunu bilmekteyiz. St. Laurent ve Riedlmayer, arşiv belgelerine dayandırdıkları çalışmalarında bu dönemlerin 1720-21; 1742; 1753-54 ve 1780 yıllarında gerçekleştirildiğini belirtmiştlerdir (St. Laurent - Riedlmayer, 1993: 77-79). Sevinç tarafindan incelenen 1720 ve 1742 yıllarına ait imar ve tamir defterleri bu sinıflandırmadaki ilk iki restorasyon dönemine denk gelmekte iken, bu yazı çerçevesinde incelenen keşif defteri ise 1780 tarihinde yapılan dördüncü restorasyon dönemine denk gelmektedir. Çalışma çerçevesinde incelenen bu keşif defteri, tamir ve restorasyon yapılacak mahaller ve kullanılacak malzemeler, miktar ve ücretlere iliş̧kin hazırlanmış bir envanter niteliği taşımaktadır. 19. yüzyılda da devam eden restorasyon çalışmalarının merkez noktasını ise yine Kubbetü's-Sahra ve Mescid-i Aksa camileri oluşturmuştur (St. Laurent ve Riedlmayer, 1993: 80-82). ${ }^{21}$

Çalışma çerçvesinde incelenen defterde de en fazla kalemde ve maliyette Harem-i Şerif içerisinde yer alan eserler kaydedilmiş olmakla birlikte, bunların yanı sıra başta Halilurrahman Makamı başta olmak üzere çok sayıda Peygamber Makamı, Haseki Sultan İmareti ve Hz. Ömer

\footnotetext{
${ }^{19} 16$. yüzyılda Kubbetü's-Sahra yapılan restorasyon çalışmalarının bir özeti ve ilgili bibliyografya için bkz. (St. Laurent, 2000: 41719; St. Laurent - Riedlmayer, 1993: 76-84).

${ }^{20}$ Sebile ait iki vakfiyeye ilişkin detaylı bir inceleme için bkz. (Eroğlu Memiş, 2017a: 90-95).

${ }^{21}$ Aslanapa ise "Kubbet el-Sahra'da Osmanlı devri tamirleri” başlıklı çalışmasında 19. yüzyılda yapılan çalışmaları liste halinde sunmuștur. Bkz. (Aslanapa, 1989: 15-18).
} 
Camii de bu restorasyon sürecine dahil edilmiştir. Ciddi bir organizasyonel beceri gerektiren bu çapta büyük imar ve ihya faaliyetlerini yürütmek üzere İstanbul'da üst düzey yöneticiler görevlendirilmiştir. Yerelde ise ehl-i vukûf olarak adlandırılan kentin önde gelenleri sürece dâhil edilmiştir. ${ }^{22}$ Kentin silüetini oluşturan bu yapıların imar ve ihyası, yapıların yüzyıllar boyunca mevcudiyetlerini korumlarına ve hizmetlerini sürdürmelerine imkân sağlamıştır.

\section{Sonuç}

Sonuç olarak, Osmanlının Kudüs'ü fethiyle beraber kent öncelikle güvenlik ve altyapı bakımlarından kuvvetlendirilmiş, kente gelen hacı, sufi ve ziyaretçilere hizmet sunacak şekilde Haseki Sultan İmareti faaliyete geçirilmiştir. Bu temel çalışmaların yanı sıra kentte mevcut yapıların tamir ve ihya çalışmaları ile işlevselliği korunmuş, yüzyıllar boyunca hizmet sunmalarına yönelik merkezi hükümetin onay ve denetimleri ile gerçekleştirilen çok sayıda geniş çaplı tamir ve bakım çalışmaları yürütülmüştür. Yapılan bu imar ve ihya faaliyetleri Osmanlı'nın Kudüs'te hüküm sürdüğü sürece devam etmiştir. Osmanlı yönetiminin meşruiyetini ve yardımseverliğini pekiştiren bu tür faaliyetler, Osmanlı yönetiminin Kudüs'e verdiği önemi de göstermiştir.

$\mathrm{Bu}$ çerçevede 18. yüzyılda yürütülen tamir ve restorasyon çalışmaları kapsamında kaleme alındığı değerlendirilen ve çalışma çerçevesinde incelenen keşif defteri, başta Harem-i Şerif alanında olmak üzere Kudüs'te çeşitli mahallerde tamir ve bakıma ihtiyaç duyan alanları, kullanılacak malzemeleri, ölçüleri ve masraflarını bir envanter olarak sunmuştur. Osmanlı yönetimince tamir ve bakımları yapılacak bu mahallerin ortak özelliği ise hayri/ kamusal nitelikte yapılar oluşlarıdır. Şüphesiz ki, sürece ilişkin yapılacak yeni çalışmalar 18. yüzyılda sürdürülen bu restorasyon sürecinin diğer detaylarına da 1şık tutacaktır.

\section{Kaynakça}

Akgündüz, A. (1994). Eski Hukukumuzda Vakıf Malların Tamiri ve Muhafazası, Vakıf Haftası [11: 1993: Ankara], Ankara: Vakıflar Genel Müdürlüğü Yay.

Aslanapa, O. (1989). Kubbet El-Sahra'da Osmanlı Devri Tamirleri, Sanat Tarihinde Doğudan Batıya, Ünsal Yüce Anısına Sempozyum Bildirileri, İstanbul: İstanbul Ünv. Edebiyat Fak. Yay.

Avc1, Y. (2004). Değişim Sürecinde Bir Osmanlı Kenti, Kudüs (1890:1914), Ankara: Phoenix Yay.

Bakırer, Ö. (1973). Vakfiyelerde Binalarin Tamirati ile İlgili Şartlar ve Bunlara Uyulmasi. Vakıflar Dergisi, 10: 113-26.

Barkan, Ö. L. (1963). XVI-XVIII. Asırlarda İnşaat İşlerinin Hukuki Durumu, İktisat ve İçtimaiyat Enstitüsü Sosyal Siyaset Konferansları, 14. Kitaptan ayrıbasım, İstanbul.

Burgoyne, M. H. (1986). Mamluk Jerusalem, London.

Cohen, A. (1989). Economic Life in Ottoman Jerusalem, Cambridge, UK: Cambridge University Press.

Cueno, P. (2000). The Urban Structure and Physical Organization of Ottoman Jersualem in the Context of Ottoman Urbanism, Ed: Sylvia Auld and Robert Hillenbrand), Ottoman Jerusalem: The Living City, 1517-1917, Londra: Altajir World of Islam Trust, 211-221.

Çetin, A. (2000). Fetva ile Tamir, Tarih ve Düşünce, 6: 62-63.

Çiftçi, C. (2004). Bursa'da Vakıfların Sosyo-Ekonomik İşlevleri, Bursa.

\footnotetext{
${ }^{22} 18$. Yüzyılda Kudüs kentinde yerel önde gelen ailelerin kadı tarafından kurulan ve kentte yapılan tamirlerin etkin bir şekilde yapılıp yapılmadığı, vakıf mülkiyet hakkı alıcısının sunmuş olduğu harcamaların onaylanması ve uzun süreli kiralamalarda kira miktarının belirlenmesi gibi hususlarda kararların alındığı komitelerde aldıkları görevlere ilişkin bir inceleme için bkz. (Eroğlu Memiş, 2016: 259-263).
} 
Demirel, Ö. (2000). Osmanlı Vakıf-Şehir İlişkisine bir Örnek: Sivas Şehir Hayatında Vakıfların Rolü, Ankara: TTK Yay.

Dündar, A. (1999). Arşivlerdeki Plan ve Çizimler Işı̆̆ı Altında Osmanlı İmar Sistemi, Ankara Üniversitesi Sosyal Bilimler Enstitüsü, Doktora Tezi, Ankara.

Dündar, A. (2001). Osmanlılarda Tamir Süreci, Çeşitleri ve Bazı Selçuklu Yapılarındaki Uygulamalar, Uluslararası Selçuklu Kültür ve Medeniyeti Kongresi [2000: Konya], I. Cilt, 269-280, Konya: Selçuk Üniversitesi Selçuklu Araştırmaları Merkezi.

El-'Arif, A. (1961). el-Mufassal fí Târîhi’l-Kuds, Kudüs.

El-Aseli, K. C. (1989). Jerusalem under the Ottomans 1516-1831 AD, Jerusalem in History, K.C. el-Aseli (ed.) Jerusalem in History, London: Scorpion Publishing Ltd., 200-224.

El-Aseli, K. C. Kudüs, Diyanet İslam Ansiklopedisi, 26 (2002): 334-338.

El-Hanbelî, M. (1973). El-Ünsü'l-Celîl bi-Târîhi'l-Kudsi ve'l-Halîl. C. II. Amman.

Erdoğan, M. (1968). Osmanlı Devrinde Anadolu Camilerinde Restorasyon Faaliyetleri, Vakıflar Dergisi, Say1 VII: 149-205.

Ergenç, Ö. (1988). Şehir Tarihi Araştırmaları Hakkında Bazı Düşünceler, Belleten, C LII/203: 667-683, Ankara: TTK Yay.

Eroğlu Memiş, Ş. (2016). Osmanlı Taşra Toplumu ve Vaklf Kurumu: Kudüs, 1703-1831, Hacettepe Üniversitesi Sosyal Bilimler Enstitüsü, Doktora Tezi, Ankara.

Eroğlu Memiş, Ş. (2017a). Osmanlı Kudüs'ünde Bir Sebil Vakfi: Çorbacı Sebili, Vakıf ve Toplum Dergisi, Vaklf Medeniyeti Kudüs, 5 Mayıs 2017: 90-95.

Eroğlu Memiş, Ş. (2017b). Hurûfât Defterlerinde Kudüs-i Şerîf Kazası: Vakıflar, Görevler ve Görevliler, İstanbul: Yeditepe Yay.

Gabriel, A. (1938). Tarihi Türk Abidelerinin Tamiri ve İhyası, Ankara: Vakıflar Genel Müdürlüğü.

Grabar, O. (1959). The Umayyad Dome of the Rock, Ars Orientalis, 3: 33-62.

Grabar, O. (1973). Formation of Islamic Art, Yale University Press.

Gündoğdu, İ. (2009). "Osmanlı Tarihi Kaynaklarından Kazaskerlik Rûznâmçe Defterleri ve Önemi”, Uluslararası İnsan Bilimleri Dergisi, c. 6 (2): 697-722.

Gürbüz, A. (1993). Toprak-Vakıf Ilişskileri Çerçevesinde XVI. Yüzyılda Amasya Sancă̆ı, Ankara Üniveristesi Sosyal Bilimler Enstirüsü, Doktora Tezi, (Ankara, 1993).

Hızlı, M. (1993): Osmanlı Vakıf Eserlerinin İnşa, Tamir ve Restorasyonları, Uludağ Üniversitesi Ilahiyat Fakültesi Dergisi, 5 (5): 219-232.

Hillenbrand, R. (2000). Introduction: Structure, Style, and Context in the Monuments of Ottoman Jerusalem, (Ed: Sylvia Auld and Robert Hillenbrand), Ottoman Jerusalem: The Living City, 1517-1917, Londra: Altajir World of Islam Trust, 1-23.

İnalcık, H. (1998). Şikâyet Hakkı: Arz-1 Hâl ve Arz-1 Mahzar'lar, Osmanlı Araştırmaları, VIIVIII: 33-54.

İnalcık, H. (2000). Osmanlı'da Devlet, Hukuk, Adalet, İstanbul: Eren Yayıncılık.

Köse, F.B. (2017). Osmanlı Dönemi Kudüs'ünde Mimari Çalışmaları, KSÜ İlahiyat Fakültesi Dergisi, 29: 27-47. 
Orbay, K. (2006). Yerel İktisadi ve Sosyal Tarih ve Kurumsal Tarih Kaynakları Olarak Vakıf Muhasebe Defterleri ve Müfredat Defterleri, XV. Türk Tarih Kongresi (11-15 Eylül 2006), Ankara.

Öztürk, N. (1983). Menşe’i ve Tarihi Gelişimi Açısından Vakıflar, Ankara, VGM Yay.

Raymond, A. (1979-1980). The Ottoman Conquest and the Development of the Great Arab Towns, International Journal of Turkish Studies 1: 84-101.

Rosen-Ayalon, M. (1989). On Suleyman's Sabils in Jerusalem, The Islamic World: From Classical to Modern Times, Essays in Honor of Bernard Lewis, C. E. Bosworth and Charles Issawi, Princeton: The Darwin Press, 589-607.

Rosen-Ayalon, M. (1989). The Early Islamic Monuments of the Haram al-Sharif: An Iconographic Study, Jerusalem: Qedem-Monographs of the Institute of Archeology, Hebrew University.

Savaş, S. (1992). Bir Tekkenin Dini ve Sosyal Tarihi, Sivas Ali Baba Zaviyesi, İstanbul.

Serin, M. (2016). Kıbrıs Kalelerinin Keşif Defterleri ve Kalelerin Tamiri (Osmanli Dönemi) http://acikkaynak.bilecik.edu.tr:8080/xmlui/handle/bilecik/973

Sevinç, T. (2016). Mescidü'l-Aksa ve Kubbetü's-Sahre Camilerinde İmar ve Tamir Faaliyetleri (1720 ve 1742), Batman Üniversitesi Yaşam Bilimleri Dergisi, 6 (1): 111-137.

Singer, A. (2004). Osmanlıda Hayırseverlik: Kudüs'te Bir Haseki Sultan Imareti, İstanbul: Tarih Vakfi Yurt Yayınları.

St. Laurent, B. and Riedlmayer, A. (1993). Restorations of Jerusalem and the Dome of the Rock and Their Political Significance, 1537-1928, Muqarnas, Vol.10: 76-84.

St. Laurent, B.(2000). The Dome of the Rock restorations and significance 1540-1918, (Ed: Sylvia Auld and Robert Hillenbrand), Ottoman Jerusalem: The Living City, 1517-1917, Londra: Altajir World of Islam Trust.

Tanman, B. ve Çobanoğlu, A.V. (2001). Osmanlı Döneminde Kudüs: Kent Dokusu, Mimarlık ve Çini Sanatına İlişsin Bir Araştırmanın İlk Sonuçları, Ortadoğu'da Osmanlı Dönemi Kültür İzleri Uluslararası Bilgi Şöleni Bildirileri (25-27 Ekim 2000, Hatay), Ankara: Atatürk Kültür Merkezi Başkanlığı Yay.: 511-543.

Tibawi, A. L. (1978). The Islamic Pious Foundations in Jerusalem, The Islamic Cultural Centre, London.

Tütüncü, M. (2006). Turkish Jerusalem (1516-1917) Ottoman Inscriptions From Jerusalem and Other Palestinian Cities, Netherlands: SOTA.

Uluçam, A. (1997). Haremü'l- Halîl, DiA, C. XV, İstanbul: TDV Yay.

Vesika ve Fotoğraflarla Osmanlı Devrine Kudüs, I-II, haz: İlhan Ovalığlu, Raşit Gündoğdu, Cevat Ekinci vd., Çamlıca Yay., İstanbul 2009.

Yediyıldız, B. (2003). XVIII. Yüzyılda Türkiye'de Vakıf Müessesesi, Bir Sosyal Tarih Incelemesi, Ankara: TTK Yay.

Yılmaz, H. İ. ve Dikmen S. Ü. (2012). Osmanlı döneminde Kullanılan Yaklaşık Maliyet Tahmin Yöntemleri, e-Journal of New World Sciences Academy, 7(1). 77.

Yüksel, H. (1998), Osmanlı Sosyal ve Ekonomik Hayatında Vakıfların Rolü_(1585-1683), Sivas: Dilek Matbaasi.

Ze'evi, D. (2000). Kudüs: 17. Yüzyılda Bir Osmanlı Sancağında Toplum ve Ekonomi, (Çev. S. Çağlayan), İstanbul: Tarih Vakfı Yurt Yay. 


\section{EK: Metin}

\begin{tabular}{|c|c|c|c|c|c|c|c|c|}
\hline 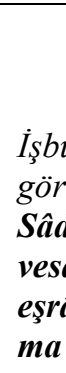 & $\begin{array}{l}\text { defte } \\
\text { tahri } \\
\text { r ola } \\
\text { ir em } \\
\text { f ve m } \\
\text { rifetiy }\end{array}$ & $\begin{array}{l}\text { 'Izz } \\
\text {-i keşfin muharrer mahal-i mübâr } \\
\text { ve ilam eyleyesiz. } \\
\text { emr-i ‘âlî mûcibince Kudüs-i Ş } \\
\text { kin-i mübârekelerin üzerlerine c } \\
\text { e'zun-ı bi’l-iftâ ve Şeyhü'l-harem } \\
\text { e yegân yegân keşif ve mesâha ol }\end{array}$ & $\begin{array}{l}\text { Bis } \\
\text { tlü } N \\
\text { kenii } \\
\text { rîfde } \\
\text { nib-i } \\
\text { Efen } \\
\text { nub }\end{array}$ & $\begin{array}{l}\text { ttâh } \\
\text { Illah } \\
\text { mâr Ăgârı } \\
\text { aki' Mes } \\
\text { 'i'den } \mathbf{K} \\
\text { ler vesâir } \\
\text { u müfre }\end{array}$ & $\begin{array}{l}\text { mrâr-l n } \\
\text { l-i Aksâa } \\
\text { ib-i sâni } \\
\text { al-i vukû } \\
\text { t defteric }\end{array}$ & $\begin{array}{l}\text { zar ve z } \\
\text { e Sahro } \\
\text { Seyh Ali } \\
\text { ma'rife } \\
\text { r ki ziki }\end{array}$ & $\begin{array}{l}\text { yâdeleri } \\
\text { ullahü'l } \\
\text { Efendi v } \\
\text { leri ve K } \\
\text { olunur. }\end{array}$ & $\begin{array}{l}\text { ar ise ana } \\
\text { Müşerrefe } \\
\text { Nakîbü'l- } \\
\text { lfa kulları } \\
\text { Sene 195." }\end{array}$ \\
\hline No & $\begin{array}{l}\text { Var.N } \\
\text { o }\end{array}$ & Tamir Mahalli & Adet & $\begin{array}{l}\text { Tûlen/ } \\
\text { Kadden } \\
\text { (mesâha) }\end{array}$ & $\begin{array}{l}\text { Arzan/ } \\
\text { Kadden } \\
\text { (mesâha) }\end{array}$ & Parmak & $\begin{array}{l}\text { Terbî‘a } \\
\text { n }\end{array}$ & $\begin{array}{l}\text { Tamir } \\
\text { Türü }\end{array}$ \\
\hline 1 & 1a & $\begin{array}{l}\text { Sahratullahü'l-Müşerrefe'nin } \\
\text { derûnunda vasat-1 kayada lâl ve } \\
\text {... Cûd rengâmizli ve seleme } \\
\text { altun şişeli ve atmacı kâri çerhi } \\
\text { felek yıldızlı ve eymece } \\
\text { göbekli necme-i ketrûs koğuşlu } \\
\text { ve on iki arşundan kirişlu tavan } \\
\text { tecdîdi }\end{array}$ & 8 & 15 & 8 & 18 & $\begin{array}{l}1050 x \\
\text { Fî } 600 \\
= \\
630000\end{array}$ & $\begin{array}{l}\text { kirişlu } \\
\text { tavan } \\
\text { tecdîdi }\end{array}$ \\
\hline 2 & $1 \mathrm{a}$ & $\begin{array}{l}\text { Mahal-i mübârekenin pervaz } \\
\text { tavanında tecdîd-i boya ve } \\
\text { bazen mahallerine ihsâb } \\
\text { ta'miri. }\end{array}$ & 8 & 23 & 5 & 18 & $\begin{array}{l}1031 x \\
\text { fi } 1200 \\
= \\
123720\end{array}$ & $\begin{array}{l}\text { ihsâb } \\
\text { ta'miri }\end{array}$ \\
\hline 3 & 1a & $\begin{array}{l}\text { Bu mahalde zengârlı buz cam } \\
\text { tecdîdi. }\end{array}$ & 6 & $\begin{array}{l}\text { Fi } 1920- \\
11520 \\
\text { Kadden }\end{array}$ & 2 & & 48 & $\begin{array}{l}\text { cam } \\
\text { tecdîdi }\end{array}$ \\
\hline 4 & 1a & $\begin{array}{l}\text { Bu mahal-i mübârekede düz } \\
\text { çerçubeli } 5 \text { rub' geçme ayna } \\
\text { camlı ve yaldızlı reft takımlı } \\
\text { cedîd çerçube. }\end{array}$ & 2 & $\begin{array}{l}3 \\
\text { Kadden }\end{array}$ & 2 & 6 & $\begin{array}{l}\text { fi } 360 x \\
13= \\
4680\end{array}$ & $\begin{array}{l}\text { cedid } \\
\text { çerçube }\end{array}$ \\
\hline 5 & & $\begin{array}{l}\text { Sahratü'l-müşerrefe derûnunda } \\
\text { mermer zarlarında cabeca } \\
\text { meremmet. }\end{array}$ & & & & & $\begin{array}{l}1000 x \\
\text { fi } 60= \\
60000\end{array}$ & $\begin{array}{l}\text { cabeca } \\
\text { meremmet }\end{array}$ \\
\hline 6 & $1 \mathrm{a}$ & $\begin{array}{l}\mathrm{Bu} \quad \text { mahalde cabeca } \\
\text { döşemelerde ta'mîr döşeme. }\end{array}$ & & & & & $\begin{array}{l}200 \times \mathrm{fi} \\
180= \\
36000\end{array}$ & $\begin{array}{l}\text { ta’mir } \\
\text { döşeme }\end{array}$ \\
\hline 7 & 1a & $\begin{array}{l}\text { Mahal-i mübârekede vasat-1 } \\
\text { 'amûdlar ve kargir ayaklar } \\
\text { beyinlerinde timur şebekelerde } \\
\text { eyvan boya tecdîdi. }\end{array}$ & 16 & $\begin{array}{l}4 \\
\text { Kadden }\end{array}$ & 4 & & $\begin{array}{l}256 \times \mathrm{fi} \\
60= \\
15360\end{array}$ & $\begin{array}{l}\text { boya } \\
\text { tecdîdi }\end{array}$ \\
\hline 8 & 1a & $\begin{array}{l}\text { Sahratullahi mübârekenin } \\
\text { cevânib-i erba'asında mevcud } \\
\text { zâriyedelerde elvan boya } \\
\text { tecdîdi. }\end{array}$ & & 70 & $\begin{array}{l}2 \\
\text { Kadden }\end{array}$ & & & $\begin{array}{l}\text { boya } \\
\text { tecdîdi }\end{array}$ \\
\hline 9 & 1a & $\begin{array}{l}\text { Sahratullahi müşerrefenin vasat } \\
\text { kubbesi kargir dıvarı birûnunda } \\
\text { üç adet terkinde cabeca keşan } \\
\text { ta'mir. }\end{array}$ & 3 & 26 & $\begin{array}{l}8 \\
\text { Kadden }\end{array}$ & & $\begin{array}{l}624 \mathrm{x} \text { fi } \\
40= \\
149760\end{array}$ & $\begin{array}{l}\text { cabeca } \\
\text { keşan } \\
\text { ta'mir }\end{array}$ \\
\hline 10 & 1a & $\begin{array}{l}\text { Bu mahalde bir adet terkende } \\
\text { bakırdan kenarlı ve çar köşeleri } \\
\text { mismarlı ve alçılı müceddeden } \\
\text { keşan vaz'1. }\end{array}$ & 1 & 26 & $\begin{array}{l}8 \\
\text { Kadden }\end{array}$ & & $\begin{array}{l}208 \times \mathrm{fi} \\
720= \\
149760\end{array}$ & $\begin{array}{l}\text { müceddede } \\
\text { n keşan } \\
\operatorname{vaz} 1^{\prime} 1\end{array}$ \\
\hline 11 & $1 \mathbf{a}$ & $\begin{array}{l}\text { Vasat kubbenin } \\
\text { erba'asında tuğra }\end{array}$ & & 104 & 2 & & $\begin{array}{l}280 \times \text { fi } \\
75= \\
15600\end{array}$ & $\begin{array}{l}\text { boya } \\
\text { tecdîdi }\end{array}$ \\
\hline
\end{tabular}




\begin{tabular}{|c|c|c|c|c|c|c|c|c|}
\hline & & $\begin{array}{l}\text { cabeca ta"miri ve elvan boya } \\
\text { tecdîdi. }\end{array}$ & & & & & & \\
\hline 12 & 1a & $\begin{array}{l}\text { Sahratullahi mübârekenin } \\
\text { bâlâsında pirinç tel örmeli ve } \\
\text { çarçubeli kafes tecdîdi. }\end{array}$ & & \begin{tabular}{|l|}
4 \\
Kadden
\end{tabular} & 2 & & $\begin{array}{l}8 \times \text { fi } \\
120= \\
960\end{array}$ & $\begin{array}{l}\text { kafes } \\
\text { tecdîdi }\end{array}$ \\
\hline 13 & 1a & $\begin{array}{l}\text { Sahratullahi müşerrefenin } \\
\text { cevânib-i erba'asında kubbede } \\
\text { kurşun başlarına Horasanlı } \\
\text { kireçli dürer. }\end{array}$ & & 312 & $\begin{array}{l}12 \\
\text { Kadden }\end{array}$ & & $\begin{array}{l}156 \times \text { fi } \\
15= \\
2340\end{array}$ & $\begin{array}{l}\text { kireçli } \\
\text { dürer }\end{array}$ \\
\hline 14 & 1a & 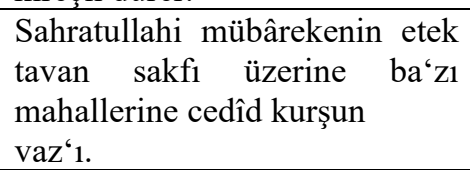 & & & & & $\begin{array}{l}\text { Adet } \\
200 . \\
800 \times \text { fi } \\
6= \\
48000\end{array}$ & $\begin{array}{l}\text { cedid } \\
\text { kurşun } \\
\text { vaz'}^{6} 1\end{array}$ \\
\hline 15 & 1a & $\begin{array}{l}\text { Etek sakfindan kubbe-i vasat } \\
\text { üzerine on arşun .... Seranlı ve } \\
\text { ketros koğuşdan kademeli } \\
\text { nerdüban tecdîdi. }\end{array}$ & & & & & $\begin{array}{l}\text { Kadem } \\
15 . \\
\text { Adet } 1 . \\
1800\end{array}$ & $\begin{array}{l}\text { nerdüban } \\
\text { tecdîdii }\end{array}$ \\
\hline 16 & 1a & $\begin{array}{lll}\text { Vasat-1 } & \text { kubbede pirinç tel } \\
\text { örmeli } & \text { ve çarçubeli } & \text { kafes } \\
\text { tecdîdi. }\end{array}$ & 4 & \begin{tabular}{l|l}
1 \\
Kadden
\end{tabular} & 1 & & $\begin{array}{ll}6 \quad x \quad \text { fi } \\
240= \\
1440\end{array}$ & $\begin{array}{l}\text { kafes } \\
\text { tecdîdi }\end{array}$ \\
\hline 17 & 1a & $\begin{array}{ll}\text { Mahal-i mübârekede } & \text { hazine } \\
\text { koğuşundan ve } & \text { kilimli } \\
\text { çiftesinden kuşaklı kapu. }\end{array}$ & 1 & \begin{tabular}{|l|}
2,5 \\
Kadden
\end{tabular} & 1 & & $\begin{array}{l}2,5= \\
600\end{array}$ & $\begin{array}{l}\text { kuşaklı } \\
\text { kapu }\end{array}$ \\
\hline 18 & $1 \mathrm{a}$ & $\begin{array}{l}\text { Sahratullahi } \text { müşerrefe } \\
\text { kubbeden fevkine varınca Çifte } \\
\text { saray arasından siranlı ve } \\
\text { hazine koğuşundan k1demli } \\
\text { nerdüban tecdîdi. }\end{array}$ & & & & & $\begin{array}{l}\text { Kadem } \\
\text { Adet } 43 \\
x \text { fi } 120 \\
=5160\end{array}$ & $\begin{array}{l}\text { nerdüban } \\
\text { tecdîdi }\end{array}$ \\
\hline 19 & $1 \mathrm{a}$ & 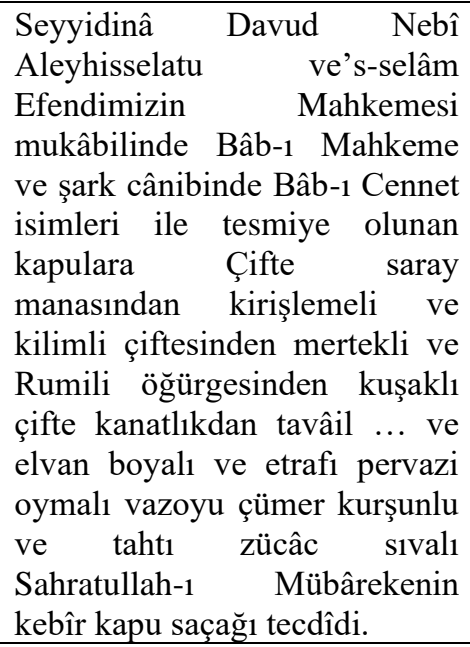 & 2 & 12 & 3 & 18 & $\begin{array}{l}\text { Parmak } \\
93.18 x \\
\text { fi } 480= \\
44640\end{array}$ & $\begin{array}{l}\text { kebir } \\
\text { kapu } \\
\text { saçağ1 } \\
\text { tecdîdi }\end{array}$ \\
\hline 20 & 1a & $\begin{array}{l}\text { Sahratullahü'l-Müsserrefenin } \\
\text { hedm olan Bâb-1 Garb'da sûm } \\
\text { ruhâm sıvalı ve kavsli ve Rumi } \\
\text { aşkımalı ve altun âyet-i } \\
\text { kerîmeli ve Sultan tarihli timur } \\
\text { zevâneli ve kurşun akıtmalı } \\
\text { sıva ve kavs tecdîdi. }\end{array}$ & & \begin{tabular}{|l|}
7 \\
Kadden
\end{tabular} & 4 & & $\begin{array}{l}28 \times \mathrm{fii} \\
2160= \\
60480\end{array}$ & $\begin{array}{l}\text { Siva ve } \\
\text { kavs tecdîdi }\end{array}$ \\
\hline 21 & 1a & $\begin{array}{l}\text { Bu mahalde cedîd kapu } \\
\text { tarafinda kitaplı ve kanatlı ve } \\
\text { zavanalı ve alçıll mermer zar } \\
\text { tecdîd. }\end{array}$ & & 13 & $\begin{array}{l}5,5 \\
\text { Kadden }\end{array}$ & 16 & $\begin{array}{l}78 \times \text { fi } \\
960= \\
74880\end{array}$ & zar tecdîdi \\
\hline 22 & 1b & $\begin{array}{l}\text { Bâb-1 Cüveylede altun silme } \\
\text { şişeli ve eymeci kâri göbekli ve }\end{array}$ & & 4 & 3 & 18 & $\begin{array}{l}14,5 x \\
\text { fi } 720= \\
10440\end{array}$ & $\begin{array}{l}\text { tavan } \\
\text { tecdîdi }\end{array}$ \\
\hline
\end{tabular}




\begin{tabular}{|c|c|c|c|c|c|c|c|c|}
\hline & & koltuklu tavan tecdîdi. & & & & & & \\
\hline 23 & $\mathbf{1 b}$ & $\begin{array}{l}\text { Bâb-1 Mübârekede } \\
\text { saçakda suğra } \\
\text { boya tecdîdi. }\end{array}$ & & 22 & 3 & & $\begin{array}{l}66 \times \mathrm{fi} \\
180 \\
=11880\end{array}$ & $\begin{array}{l}\text { boya } \\
\text { tecdîdi }\end{array}$ \\
\hline 24 & 1b & $\begin{array}{l}\text { Mahal-i Mübârekenin } \\
\text { tarafeynde kargir divar tecdîdi. }\end{array}$ & & 7 & 4 & & $\begin{array}{l}28 \times \text { fi } \\
240= \\
6720\end{array}$ & $\begin{array}{l}\text { divar } \\
\text { tecdîdi }\end{array}$ \\
\hline 25 & 1b & $\begin{array}{l}\text { Bu mahal-i şerîfde kapu ve } \\
\text { odalar üzerinde Çifte saray } \\
\text { manesinden mertekli ve kirişli } \\
\text { ve çiviyle kurşunlu ve ..... } \\
\text { sivalı sakf tecdîd. }\end{array}$ & & 18 & 8,5 & & $\begin{array}{l}153 \times \text { fi } \\
180= \\
27540\end{array}$ & $\begin{array}{l}\text { sakıf } \\
\text { tecdîdi }\end{array}$ \\
\hline 26 & $1 \mathrm{~b}$ & 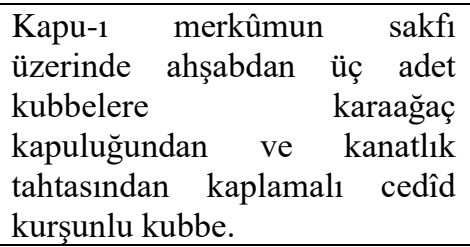 & 3 & 3 & 1,5 & & $\begin{array}{l}43,5 \\
33,5 x \\
\text { fi } 840= \\
28350\end{array}$ & $\begin{array}{l}\text { cedîd } \\
\text { kurşunlu } \\
\text { kubbe }\end{array}$ \\
\hline 27 & $\mathbf{1 b}$ & $\begin{array}{l}\text { Kapu-1 mübârekenin on arşun } \\
\text { câbeden çarçubeli ve kuşaklu } \\
\text { ve bir tarafı servi tahtasından } \\
\text { ve bir tarafı hırna koğuşundan } \\
\text { kaplamalı ve yüzü parça pirinç } \\
\text { tahta kaplamalı ve şişeleri ve } \\
\text { mismarları bakırdan dökme } \\
\text { kapu tecdîdi. }\end{array}$ & & $\begin{array}{l}\text { Kadden } \\
\text { masaha } \\
5,5\end{array}$ & 3,5 & & $\begin{array}{l}19 \times \text { fi } \\
720= \\
13860\end{array}$ & $\begin{array}{l}\text { bakırdan } \\
\text { dökme } \\
\text { kapu } \\
\text { tecdî́di }\end{array}$ \\
\hline 28 & $\mathbf{1 b}$ & $\begin{array}{l}\mathrm{Bu} \text { mahalde kapular } \\
\text { beynlerinde beş adet odanın } \\
\text { tavanı ve döșemeleri tecdîdi. }\end{array}$ & 5 & & & & $\begin{array}{l}173 \times \text { fi } \\
240= \\
41520\end{array}$ & $\begin{array}{l}\text { tavan ve } \\
\text { dösseme } \\
\text { tecdîdi }\end{array}$ \\
\hline 29 & 1b & $\begin{array}{l}\text { Kapular beynlerinde ketanlı } \\
\text { beyaz sıva tecdîdi. }\end{array}$ & & 100 & $\begin{array}{l}\text { Kadden } \\
7\end{array}$ & & $\begin{array}{l}700 \times \text { fi } \\
20= \\
14000\end{array}$ & sıva tecdîdi \\
\hline 30 & $\mathbf{1 b}$ & $\begin{array}{l}\text { Kapu-1 mezbâre kufl ve miftâh } \\
\text { tecdîdi. }\end{array}$ & 2 & & & & $\begin{array}{l}2 \times \text { fi } \\
480= \\
960\end{array}$ & $\begin{array}{l}\text { kufl ve } \\
\text { miftâh } \\
\text { tecdîdi }\end{array}$ \\
\hline 31 & $1 \mathrm{~b}$ & $\begin{array}{l}\text { Garb cânibinde olan kapu } \\
\text { mahallinden nerdüban başına } \\
\text { ketros kurşunundan ve çifte } \\
\text { saray bânesinden kuşaklı sahın } \\
\text { üzerine ahşabdan tarik. }\end{array}$ & & 16 & 2 & & $\begin{array}{l}19 \times \text { fi } \\
120= \\
22800\end{array}$ & $\begin{array}{l}\text { ahşabdan } \\
\text { tarik }\end{array}$ \\
\hline 32 & $\mathbf{1 b}$ & $\begin{array}{l}\text { Kıble cânibinde Bâb-1 Kebîre } \\
\text { saray bânesinden kirişmeli ve } \\
\text { kilimli çiftesinden mertekli ve } \\
\text { Rumili ögürgesinden kuşaklı } \\
\text { çifte kanatlıkdan tavan ve silme } \\
\text { şişeli ve etrafı pervazi örtmeli } \\
\text { ve üzeri sıvalı ve cedit kurşunlu } \\
\text { tavan ve sakfı tecdîdi. }\end{array}$ & & 21 & 7,5 & & $\begin{array}{l}157 \\
\text { bucuk } x \\
\text { fi } 240= \\
37800\end{array}$ & $\begin{array}{l}\text { tavan ve } \\
\text { sakfi } \\
\text { tecdîdi }\end{array}$ \\
\hline 33 & $\mathbf{1 b}$ & $\begin{array}{l}\text { Mahal-i mübârekenin tavanında } \\
\text { ve tuğra saçağında elvan boya } \\
\text { tecdîdi. }\end{array}$ & & 21 & 6 & 6 & $\begin{array}{l}132 \times \text { fi } \\
60=792 \\
0\end{array}$ & $\begin{array}{l}\text { boya } \\
\text { tecdîdi }\end{array}$ \\
\hline 34 & $\mathbf{1 b}$ & $\begin{array}{l}\text { Sahratullahü'l-Müşerrefe'nin } \\
\text { taşra kargir divarın cevânib-i } \\
\text { erba'asında bakırdan geçme } \\
\text { kenetli ve alçll mermer zar } \\
\text { tecdîdi. }\end{array}$ & 4 & $32-32$ & $\begin{array}{l}\text { Kadden } \\
5,5\end{array}$ & & $\begin{array}{l}352 \times \text { fi } \\
360= \\
126720\end{array}$ & $\begin{array}{l}\text { mermer zar } \\
\text { tecdîdi }\end{array}$ \\
\hline 35 & $\mathbf{1 b}$ & Kezâlik mermer zarlarında & 4 & $32-32$ & Kadden & & $704-176$ & mermer zar \\
\hline
\end{tabular}




\begin{tabular}{|c|c|c|c|c|c|c|c|c|}
\hline & & $\begin{array}{l}\text { kaptırır olunanlar mahallinden } \\
\text { kalkub kenetli ve alç1l vaz'-1 } \\
\text { mermer zar ta'mîri. }\end{array}$ & & & 5,5 & & $\begin{array}{l}\mathrm{x} \text { fi } \\
120= \\
21120\end{array}$ & ta'mîri \\
\hline 36 & 1b & $\begin{array}{l}\text { Mahal-i mübârekenin mermer } \\
\text { zarları fevkinde bakırdan } \\
\text { geçme kenetli ve bakırdan } \\
\text { mismarlı ve alçılı keşan ta'mîri. }\end{array}$ & 4 & $32-32$ & $\begin{array}{l}\text { Kadden } \\
10\end{array}$ & & $\begin{array}{l}1280- \\
640 \times \text { fi } \\
240= \\
53600\end{array}$ & $\begin{array}{l}\text { keşan } \\
\text { ta'mîri }\end{array}$ \\
\hline 37 & $1 \mathrm{~b}$ & $\begin{array}{l}\text { Bu mahalde şimâl ve garb } \\
\text { câniblerinde bakır kenetli ve } \\
\text { mismarl geçme keşan tecdîdi. }\end{array}$ & 4 & $32-32$ & $\begin{array}{l}\text { Kadden } \\
10\end{array}$ & & $\begin{array}{l}1280- \\
640 \times \text { fi } \\
720= \\
460800\end{array}$ & $\begin{array}{l}\text { keşan } \\
\text { tecdîdi }\end{array}$ \\
\hline 38 & 1b & $\begin{array}{l}\text { Mi'râc-1 şerîf kayası derûnunda } \\
\text { bakır kanatll ve alç1l cedîd } \\
\text { keşan. }\end{array}$ & & $\begin{array}{l}\text { Kadden } \\
4\end{array}$ & 3 & & $\begin{array}{l}12 \times \text { fi } \\
720= \\
8640\end{array}$ & cedîd keşan \\
\hline 39 & 1b & $\begin{array}{l}\text { Mahal-i mübârekenin mermer } \\
\text { zarlarında meremmat-1 dâr/dûr. }\end{array}$ & & & & & $\begin{array}{l}40 \times \mathrm{fi} \\
120= \\
4800\end{array}$ & $\begin{array}{l}\text { meremm } \\
\text { at-1 } \\
\text { dâr/dûr. }\end{array}$ \\
\hline 40 & $1 \mathrm{bb}$ & $\begin{array}{l}\text { Mahal-i mübârekenin } \\
\text { derûnunda badana. }\end{array}$ & & & & & $\begin{array}{l}120 \times \mathrm{xi} \\
4=480\end{array}$ & badana \\
\hline 41 & $1 \mathrm{~b}$ & $\begin{array}{l}\text { Bu mahalde işleme buz cam } \\
\text { tecdîdi. }\end{array}$ & 5 & $\begin{array}{l}1,5 \\
\text { kadden }\end{array}$ & 1,5 & & $\begin{array}{l}10 \mathrm{x} \mathrm{fi} \\
360= \\
360\end{array}$ & cam tecdîdi \\
\hline 42 & $\mathbf{1 b}$ & $\begin{array}{l}\text { Mahal-i } \quad \text { mübârekenin } \\
\text { birûnunda kenetli ve kireçli ve } \\
\text { sıvacı kêri azb nakışlı sıva } \\
\text { tecdîdi. }\end{array}$ & 8 & 3 & 4 & & $\begin{array}{l}96 \times \mathrm{fi} \\
30= \\
2880\end{array}$ & \begin{tabular}{|l|} 
SIva \\
tecdîdi
\end{tabular} \\
\hline 43 & $1 \mathbf{1 b}$ & $\begin{array}{l}\text { Seyyidinâ } \\
\text { Aleyhisselam Efendimizin } 14 \\
\text { 'amûd üzerine Mahkeme-i } \\
\text { şeriflerinde } \\
\text { öğürgesinden girişmeli ve ve } \\
\text { ketrus koğuşdan tavanlı bük ve } \\
\text { zencefire viç civid boyalı ve } \\
\text { avdanlıklı silme şişeli ve } \\
\text { altunlu ve şilteler ve satıllarna } \\
\text { oymacı kêri armalı tavan } \\
\text { tecdîdi. }\end{array}$ & 6 & 7 & 4 & 8 & $\begin{array}{l}182 \times \text { fi } \\
720= \\
131040\end{array}$ & $\begin{array}{l}\text { tavan } \\
\text { tecdîdi }\end{array}$ \\
\hline 44 & 1b & $\begin{array}{l}\text { Mahal-i mübârekede 'amûd } \\
\text { beynlerinde altun silme şişeli } \\
\text { ve altunlu çifte kanatlıkdan } \\
\text { girilme tecdîdi. }\end{array}$ & & & & & $\begin{array}{l}57 \\
\text { buçuk x } \\
\text { fi } 480 \\
=27600\end{array}$ & $\begin{array}{l}\text { girilme } \\
\text { tecdîdi }\end{array}$ \\
\hline 45 & 1b & $\begin{array}{l}\text { Mahal-i mübârekenin mihrâb1 } \\
\text { derûn ve birûnunda mermer zar } \\
\text { tecdîdi. }\end{array}$ & & 11 & 4 & & $\begin{array}{l}44 \times \text { fi } \\
600= \\
26400\end{array}$ & \begin{tabular}{|l} 
mermer zar \\
tecdîdi
\end{tabular} \\
\hline 46 & 1b & $\begin{array}{l}\text { Mahal-i mübârekenin } \\
\text { tahtahunba mermer döşemeleri } \\
\text { bi'l-cümle mahallinden kalkub } \\
\text { yine mahallerine vaz've bazen } \\
\text { tecdîd. }\end{array}$ & 6 & 7 & 4 & 8 & $\begin{array}{l}182 \times \text { fi } \\
240= \\
43680\end{array}$ & \begin{tabular}{|l} 
Dössemeleri \\
$\mathrm{n}$ vaz' ve \\
bazen \\
tecdìd
\end{tabular} \\
\hline 47 & $1 \mathrm{~b}$ & $\begin{array}{l}\text { Mahal-i mübârekenin sakfi } \\
\text { mahallinde kargir } \\
\text { keşan ta'mir tecdîdi. }\end{array}$ & & & & & $\begin{array}{l}21 \times \text { fi } \\
240= \\
5040\end{array}$ & $\begin{array}{l}\text { keşan } \\
\text { ta'mir } \\
\text { tecdîdi }\end{array}$ \\
\hline 48 & 1b & $\begin{array}{l}\text { Sahratullahü'l-Müşerrefe'nin } \\
\text { sahın başlarında sekiz adet } \\
\text { nerdüban başlarında meşe } \\
\text { 'amûdlar üzerine kavslerde } \\
\text { kenetli ve kireçli beyaz sıva } \\
\text { tecdîdi. }\end{array}$ & & 320 & $\begin{array}{l}4 \\
\text { kadden }\end{array}$ & & $\begin{array}{l}1280 \cdot x \\
\text { fi } 30= \\
38400\end{array}$ & sıva tecdîdi \\
\hline 49 & $\mathbf{1 b}$ & Kubbetü'l-Ervâh ve Kubbetü'l- & & & & & $150 \times \mathrm{fi}$ & \begin{tabular}{|l} 
siva tecdîdi \\
\end{tabular} \\
\hline
\end{tabular}




\begin{tabular}{|c|c|c|c|c|c|c|c|}
\hline & & $\begin{array}{l}\text { erbâh ve Kubbetü'l-ahmâr } \\
\text { derûnlarında horasanlı kanatli } \\
\text { beyaz sıva tecdîdi. }\end{array}$ & & & & $\begin{array}{l}75= \\
11250\end{array}$ & \\
\hline 50 & $1 \mathrm{~b}$ & $\begin{array}{l}\text { Sahratullahü'l-Müşerrefe'nin } \\
\text { kıble cânibinde sahın başında } \\
\text { kebîr Mihrâb-1 Hanefîde kenatlı } \\
\text { ve mermer sıvalı ve nakışlı } \\
\text { mihrabda sıva tecdîdi. }\end{array}$ & & & & $\begin{array}{l}50 \times \text { fi } \\
120= \\
6000\end{array}$ & siva tecdîdi \\
\hline 51 & $1 \mathrm{~b}$ & $\begin{array}{lr}\text { Mihrâb-1 şerîfin } & \text { ittisalinde } \\
\text { minber-i } & \text { kebîrde } \\
\text { kademelerinde } & \text { def'a } \\
\text { beynlerinde timur kenetli ve } \\
\text { kurşun akitmalı minber } \\
\text { meremmât. }\end{array}$ & & & & $\begin{array}{l}10 \times \mathrm{fi} \\
60=600\end{array}$ & $\begin{array}{l}\text { minber } \\
\text { meremmâtı }\end{array}$ \\
\hline 52 & 1b & $\begin{array}{l}\text { Sahratullahü'l-Mübârekenin } \\
\text { fevkinde ve tahtında bi'l-cümle } \\
\text { odalarda kenetli ve kireçli } \\
\text { beyaz sıva tecdîd-i odahat. }\end{array}$ & 56 & & & $\begin{array}{l}10100 \mathrm{x} \\
\text { fi } 20 \\
=20200 \\
0\end{array}$ & siva tecdîdi \\
\hline 53 & $\mathbf{1 b}$ & $\begin{array}{l}\text { Merkûm odaların pencere } \\
\text { kanatlarında hazîne koğuşdan } \\
\text { tecdîdi. }\end{array}$ & 79 & 2 & 1 & $\begin{array}{l}158 \times \mathrm{xi} \\
60= \\
9680\end{array}$ & $\begin{array}{l}\text { hazine } \\
\text { koğuşdan } \\
\text { tecdîdi }\end{array}$ \\
\hline 54 & $1 \mathrm{~b}$ & $\begin{array}{l}\text { Bu mahalde orta tahtadan } \\
\text { geçmeli camlı ve çarçube } \\
\text { tecdîdi. }\end{array}$ & 10 & 2 & 1 & $\begin{array}{l}20 \times \mathrm{xfi} \\
120 \\
=2400\end{array}$ & $\begin{array}{l}\text { çarçube } \\
\text { tecdîdi }\end{array}$ \\
\hline 55 & $1 \mathrm{~b}$ & $\begin{array}{l}\text { Zikir olunan odaların kapuları } \\
\text { tecdîd. }\end{array}$ & 61 & 2,5 & 1 & $\begin{array}{l}152 \\
\text { buçuk } x \\
\text { fi } 60= \\
9150\end{array}$ & $\begin{array}{l}\text { kapular } \\
\text { tecdîdi }\end{array}$ \\
\hline 56 & $1 \mathrm{~b}$ & $\begin{array}{l}\text { Mahal-i merkûmun kapularına } \\
\text { ve kanatlarına ve çerçubelerine } \\
\text { ve timurlarına boya tecdîdi. }\end{array}$ & & & & $\begin{array}{l}310 \times \text { fi } \\
60= \\
18600\end{array}$ & $\begin{array}{l}\text { boya } \\
\text { tecdîdi }\end{array}$ \\
\hline 57 & $1 \mathrm{~b}$ & $\begin{array}{l}\text { Mezbûr odaların sakfında küllü } \\
\text { ve kireçli ve kalemkârî sıva } \\
\text { tecdîdi. }\end{array}$ & 49 & & & $\begin{array}{l}3480 x \\
\text { fi } 20= \\
69600\end{array}$ & siva tecdîdi \\
\hline 58 & $2 a$ & $\begin{array}{l}\text { Mescid-i Aksâ’nın vasat } \\
\text { kubbesi yemîninde vâki' on } \\
\text { arşun orta câbeden kireçlemeli } \\
\text { ketros koğuşundan tavanlı ve } \\
\text { elvan boyalı ve kurşun tahta } \\
\text { kireçli sıva ve üzeri cedîd } \\
\text { kurşunlu tavan tecdîd. }\end{array}$ & & 80 & 9 & $\begin{array}{l}720 \times \text { fi } \\
360= \\
259200\end{array}$ & $\begin{array}{l}\text { tavan } \\
\text { tecdîdi }\end{array}$ \\
\hline 59 & $2 a$ & $\begin{array}{l}\text { Bu mahalde dıvarı tarafeynine } \\
\text { horasanlı ve } \\
\text { kireçli ve aşı boyalı sıva } \\
\text { tecdîdi. }\end{array}$ & & 150 & 4,5 & $\begin{array}{l}675 \times \text { fi } \\
200= \\
13500\end{array}$ & siva tecdîdi \\
\hline 60 & $2 a$ & $\begin{array}{l}\text { Bu mahalde tuğra saçak tamiri } \\
\text { ve boyalı } \\
\text { tavan tecdîdi.Cümle sakıflarda } \\
\text { kurşun } \\
\text { başlarına horasanlıdûr. }\end{array}$ & & 80 & 18 & $\begin{array}{l}60 \times \mathrm{xi} \\
60=360 \\
0\end{array}$ & $\begin{array}{l}\text { tavan } \\
\text { tecdîdi }\end{array}$ \\
\hline 61 & & $\begin{array}{l}\text { Cümle sakıflarda kurşun } \\
\text { başlarına horasanlı dûr. }\end{array}$ & & 300 & 12 & $\begin{array}{l}150 \times \text { fi } \\
30= \\
4500\end{array}$ & $\begin{array}{l}\text { Horasanl1 } \\
\text { dûr }\end{array}$ \\
\hline 62 & $2 a$ & $\begin{array}{l}\text { Yine Mescid-i Aksânın vasat } \\
\text { kubbesi } \\
\text { beynlerinde on arşun orta } \\
\text { cabeden kireçli ve } \\
\text { ketros koğuşundan tavanlı ve } \\
\text { elvan boyalı ve }\end{array}$ & & 61 & 9 & $\begin{array}{l}549 \times \text { fi } \\
360=19 \\
7640\end{array}$ & $\begin{array}{l}\text { tavan } \\
\text { tecdîdi }\end{array}$ \\
\hline
\end{tabular}




\begin{tabular}{|c|c|c|c|c|c|c|c|c|}
\hline & & $\begin{array}{l}\text { kurşun tahtı sıvalı üzeri cedîd } \\
\text { kurşunlu tavan } \\
\text { tecdîdi. }\end{array}$ & & & & & & \\
\hline 63 & $2 \mathbf{a}$ & $\begin{array}{l}\text { Bu mahalde tuğra saçak tamiri } \\
\text { ve altun boya } \\
\text { tecdîdi. }\end{array}$ & & 80 & 18 & & $\begin{array}{l}60 \times \mathrm{xfi} \\
60= \\
3600\end{array}$ & $\begin{array}{l}\text { boya } \\
\text { tecdîdi }\end{array}$ \\
\hline 64 & $2 a$ & $\begin{array}{l}\text { Bu mahalde vâki sayir } \\
\text { civarında timur tel } \\
\text { örmeli ve çarcubeli cedîd tel } \\
\text { kafes. }\end{array}$ & 24 & 2 & 1,5 & & $\begin{array}{l}72 \times \text { fi } \\
120= \\
8640\end{array}$ & $\begin{array}{l}\text { cedîd tel } \\
\text { kafes }\end{array}$ \\
\hline 65 & $2 \mathbf{a}$ & $\begin{array}{l}\text { Bu mahalde pencerenin buz } \\
\text { camlarinda } \\
\text { ta'mir. }\end{array}$ & 22 & $\begin{array}{l}2 \\
\text { kadden }\end{array}$ & 1,5 & & $\begin{array}{l}22 \text { adet } \\
\mathrm{x} \mathrm{fi} 360 \\
=7920\end{array}$ & $\begin{array}{l}\text { camlarda } \\
\text { ta'mir }\end{array}$ \\
\hline 66 & $2 \mathbf{a}$ & $\begin{array}{l}\text { Mescid-i Aksânın Dûr } \\
\text { kubbesinde dıvarda } \\
\text { horasanlı ve kireçli ve aşı } \\
\text { boyalı sıva tecdîdi. }\end{array}$ & & 33 & $\begin{array}{l}4 \\
\text { Kadden }\end{array}$ & & $\begin{array}{l}132 \times \text { fi } \\
30= \\
3960\end{array}$ & sıva tecdîdi \\
\hline 67 & $2 \mathbf{a}$ & $\begin{array}{l}\text { Kubbe-i merkûmunda tuğra } \\
\text { saçak tecdîdi. }\end{array}$ & & 45 & 1 & 6 & $\begin{array}{l}56 \times \mathrm{xfi} \\
120= \\
6120\end{array}$ & $\begin{array}{l}\text { saçak } \\
\text { tecdîdi }\end{array}$ \\
\hline 68 & $2 a$ & $\begin{array}{c}\text { Bu mahalde buz ve astar } \\
\text { camları tecdîdi. }\end{array}$ & 8 & $\begin{array}{l}2 \\
\text { Kadden }\end{array}$ & 2,5 & & $\begin{array}{l}\text { Adet } 8 \\
\mathrm{x} \text { fi } \\
1200 \\
=9600\end{array}$ & $\begin{array}{l}\text { camlar } \\
\text { tecdîdi }\end{array}$ \\
\hline 69 & $2 \mathbf{a}$ & $\begin{array}{l}\text { Mescid-i Aksânın Kapu } \\
\text { cânibinde dıvarda } \\
\text { astar cam tecdîdi. }\end{array}$ & 36 & $\begin{array}{l}3,5 \\
\text { Kadden }\end{array}$ & 2,5 & & $\begin{array}{l}36 \text { Adet } \\
x \text { fi } \\
2040= \\
73440\end{array}$ & cam tecdîdi \\
\hline 70 & $2 \mathbf{a}$ & $\begin{array}{l}\text { Mescid-i Aksâ sakıflarında } \\
\text { cedîd kurşun vaz'1 ta'miri. }\end{array}$ & 300 & & & & $\begin{array}{l}\text { Adet } \\
300 . x \\
\text { fi } 6= \\
8440- \\
50400\end{array}$ & $\begin{array}{l}\text { kurssun } \\
\text { vaz'1 } \\
\text { ta'miri }\end{array}$ \\
\hline 71 & $2 \mathbf{a}$ & $\begin{array}{l}\text { Mescid-i Aksânın cânib-i } \\
\text { şimâlde ketenli ve kireçli taş } \\
\text { kesmeli sıva tecdîdi. }\end{array}$ & & 10 & $\begin{array}{l}4 \\
\text { Kadden }\end{array}$ & & $\begin{array}{l}40 \times \mathrm{xfi} \\
25= \\
1000\end{array}$ & siva tecdîdi \\
\hline 72 & $2 \mathbf{2 a}$ & Bu mahalde astar cam tecdîdi. & 3 & $\begin{array}{l}2,5 \\
\text { Kadden }\end{array}$ & 2 & & $\begin{array}{l}15 \mathrm{x} \text { fi } \\
240= \\
3600\end{array}$ & \\
\hline 73 & $2 \mathbf{a}$ & $\begin{array}{l}\text { Mescid-i Aksâ derûnunda } \\
\text { 'amûdlar üzerinde } \\
\text { tarafeyn kavslerde badana. }\end{array}$ & & 20 & $\begin{array}{l}20 \\
\text { Kadden }\end{array}$ & & $\begin{array}{l}5600 \times \\
\text { fi } 4= \\
22400\end{array}$ & $\begin{array}{l}\text { kavslerde } \\
\text { badana }\end{array}$ \\
\hline 74 & $2 a$ & $\begin{array}{l}\text { Bu mahalde tarafeyn } \\
\text { 'amûdlarda somalı } \\
\text { taklidi ve ketenli ve mermer } \\
\text { sivalı 'amûd. }\end{array}$ & 12 & $\begin{array}{l}6 \\
\text { kadden }\end{array}$ & $\begin{array}{l}4 \\
\text { dûren }\end{array}$ & & $\begin{array}{l}288 \times \text { fi } \\
300= \\
8640\end{array}$ & 'amûd \\
\hline 75 & $2 \mathbf{a}$ & $\begin{array}{ll}\text { Yine } & \begin{array}{l}\text { mahal-i mübârekede } \\
\text { yemîn ve yesârın }\end{array} \\
\text { koltuk } & \begin{array}{l}\text { kubbelerinde ketenli } \\
\text { beyaz siva }\end{array} \\
\text { tecdîdi. }\end{array}$ & & 180 & $\begin{array}{l}52 \\
\text { dûren }\end{array}$ & & $\begin{array}{l}9360 x \\
\text { fi } 20= \\
187200\end{array}$ & siva tecdîdi \\
\hline 76 & $2 \mathbf{a}$ & $\begin{array}{l}\text { Bu mahalde 'amûdlar ve } \\
\text { kavsler beynlerinde } \\
\text { ahşab cisirlere elvan boya } \\
\text { tecdîdi ve bazen } \\
\text { mahalleri neccarkârî ta'mîr-i } \\
\text { minber. }\end{array}$ & 53 & & & & $\begin{array}{l}700 \times \text { fi } \\
60= \\
42000\end{array}$ & $\begin{array}{l}\text { boya } \\
\text { tecdîdi, } \\
\text { ta'mîr-i } \\
\text { minber }\end{array}$ \\
\hline 77 & $2 \mathbf{a}$ & $\begin{array}{lrr}\begin{array}{l}\text { Mescid-i } \\
\text { cânibinde }\end{array} & \text { Aksânın } \begin{array}{r}\text { yemîn } \\
\text { kabuluğundan } \\
\text { kapu. }\end{array} \\
\text { kagağaçramacı kârî }\end{array}$ & 1 & 4 & 2 & 18 & $\begin{array}{l}11,5= \\
5080\end{array}$ & kârî kapu \\
\hline
\end{tabular}




\begin{tabular}{|c|c|c|c|c|c|c|c|}
\hline 78 & $2 a$ & $\begin{array}{l}\text { Mescid-i Aksâda mihrâb-1 kebîr } \\
\text { bâlâsında elvan nakışlı cam buz } \\
\text { tecdîdi. }\end{array}$ & 2 & 3 & 2 & $\begin{array}{l}+7=14 \\
\times \mathrm{fi} \\
360= \\
5040\end{array}$ & buz tecdîdi \\
\hline 79 & $2 a$ & $\begin{array}{l}\text { Bu mahal-i mübârekede yemîn } \\
\text { ve yesârında tarafeyn kavslerde } \\
\text { bi'l-cümle badana. }\end{array}$ & & & & $\begin{array}{l}1000 x \\
\text { fi } 4= \\
40000\end{array}$ & badana \\
\hline 80 & $2 a$ & $\begin{array}{c}\mathrm{Bu} \text { mahal-i mübârekede } \\
\text { mermer zarflarında } \\
\text { cabeca müremmimât-1 zar. }\end{array}$ & & & & $\begin{array}{l}240 \times \text { fi } \\
60= \\
14400\end{array}$ & $\begin{array}{l}\text { müremmim } \\
\text { at-1 zar }\end{array}$ \\
\hline 81 & $2 a$ & $\begin{array}{l}\text { Mihrâb-1 kebîrin yemîn ve } \\
\text { yesârında ceviz } \\
\text { çarcubeli ve nim zira“ penbe } \\
\text { cam geçmeli ve } \\
\text { yaldızlı rahtlı çarçube tecdîdi. }\end{array}$ & 4 & 3 & 2 & $\begin{array}{l}12 \times \mathrm{fi} \\
360= \\
4320\end{array}$ & $\begin{array}{l}\text { çarçube } \\
\text { tecdîdi }\end{array}$ \\
\hline 82 & $2 a$ & $\begin{array}{l}\text { Mahfel-i kebîrde ve hatîb } \\
\text { hücresinde timur } \\
\text { şebeke de elvan boya tecdîdi. }\end{array}$ & & & & $\begin{array}{l}155 \times \text { fi } \\
60= \\
9300\end{array}$ & $\begin{array}{l}\text { boya } \\
\text { tecdiddi }\end{array}$ \\
\hline 83 & $2 a$ & $\begin{array}{l}\text { Mescid-i Aksânın yemin } \\
\text { cânibinde Mâlikî } \\
\text { Câmi-i Şerîfine varınca koltuk } \\
\text { kubbede sıva } \\
\text { tecdîdi. }\end{array}$ & & 117 & 23 & $\begin{array}{l}2691 x \\
\text { fi } 20 \\
=53820\end{array}$ & siva tecdîdi \\
\hline 84 & $2 a$ & $\begin{array}{l}\text { Kesrelik kubbelerde bi’l-cümle } \\
\text { badana. }\end{array}$ & & 117 & 23 & $\begin{array}{l}2691 \mathrm{x} \\
\text { fi } 4= \\
10764\end{array}$ & badana \\
\hline 85 & $2 a$ & $\begin{array}{l}\text { Bu mahalde pencere } \\
\text { kanatlarında cabeca } \\
\text { müremmimat. }\end{array}$ & 12 & 3 & 2,5 & $\begin{array}{l}90 \times \mathrm{fi} \\
30=270 \\
0\end{array}$ & $\begin{array}{l}\text { müremmim } \\
\text { at }\end{array}$ \\
\hline 86 & $2 \mathbf{a}$ & $\begin{array}{l}\text { Bu mahalde pencere örme tel } \\
\text { çarçubeli kafes } \\
\text { tecdîdi. }\end{array}$ & 8 & $\begin{array}{l}3 \\
\text { kadden }\end{array}$ & 2,5 & $\begin{array}{l}56 \times \text { fi } \\
120= \\
6720\end{array}$ & $\begin{array}{l}\text { kafes } \\
\text { tecdîdi }\end{array}$ \\
\hline 87 & $2 a$ & $\begin{array}{l}\text { Mescid-i Aksânın mevcud } \\
\text { bâb-1 kebîrlerinde } \\
\text { elvan boya tecdîdi. }\end{array}$ & 7 & $\begin{array}{l}3 \\
\text { kadden }\end{array}$ & 4,5 & $\begin{array}{l}60 \times \mathrm{xfi} \\
60= \\
3600\end{array}$ & $\begin{array}{l}\text { boya } \\
\text { tecdîdi }\end{array}$ \\
\hline 88 & $2 a$ & $\begin{array}{l}\text { Mahal-i mübârekede son } \\
\text { cemaat kubbelerde } \\
\text { ve kavslerde ketenli ve kireçli } \\
\text { beyaz sıva } \\
\text { tecdîdi. }\end{array}$ & & 3 & 19 & $\begin{array}{l}1330 x \\
\text { fi } 20= \\
26600\end{array}$ & sıva tecdîdi \\
\hline 89 & $2 a$ & $\begin{array}{c}\text { Mahal-i mübârekede kapılar } \\
\text { üzerinde Rûmi } \\
\text { işleme divar camı tecdîdi. }\end{array}$ & 7 & 4 & 2 & $\begin{array}{l}8 \times \mathrm{x} \mathrm{fi} \\
960 \\
=7680\end{array}$ & $\begin{array}{l}\text { dıvar camı } \\
\text { tecdîdi }\end{array}$ \\
\hline 90 & $2 a$ & $\begin{array}{l}\text { Mescid-i Aksânın yesâr } \\
\text { cânibinde kargir } \\
\text { divarlarında horasanlı ve kireçli } \\
\text { dûr. }\end{array}$ & & 130 & $\begin{array}{l}10 \\
\text { kadden }\end{array}$ & $\begin{array}{l}1700 x \\
\text { fi } 60 \\
=10200 \\
0\end{array}$ & dûr \\
\hline 91 & & $\begin{array}{l}\text { Mescid-i Aksânın şark ve } \\
\text { yemîninde vâki } \\
\text { kavslerde ve kargir dıvarlarında } \\
\text { ketenli ve } \\
\text { kireçli ve taş kesmeli sıva } \\
\text { tecdîdi. }\end{array}$ & & & & $\begin{array}{l}1780 x \\
\text { fi } 20= \\
35600\end{array}$ & sıva tecdîdi \\
\hline 92 & $2 a$ & $\begin{array}{l}\text { Mescid-i Aksâ'ya muttasıl } \\
\text { mağazanın kargir } \\
\text { dıvarı hedm ve tecdîdi. }\end{array}$ & & 10 & $\begin{array}{l}10 \\
\text { kadden }\end{array}$ & $\begin{array}{l}300 \times \text { fi } \\
240= \\
72000\end{array}$ & $\begin{array}{l}\text { hedm ve } \\
\text { tecdîdi }\end{array}$ \\
\hline 93 & $2 a$ & $\begin{array}{l}\text { Mağaza-i merkûmun şark } \\
\text { cânibinde taş kesmeli ve ketenli } \\
\text { ve kireçli sıva tecdîdi. }\end{array}$ & & 65 & $\begin{array}{l}11 \\
\text { kadden }\end{array}$ & $\begin{array}{l}715 \times \text { fi } \\
30= \\
21450\end{array}$ & sıva tecdîdi \\
\hline
\end{tabular}




\begin{tabular}{|c|c|c|c|c|c|c|c|}
\hline 94 & $2 \mathbf{a}$ & $\begin{array}{l}\text { Mahal-i sakflarında küllü ve } \\
\text { kireçli kalemkârî sıva tecdîdi. }\end{array}$ & & 63 & 30 & $\begin{array}{l}1890 x \\
\text { fi } 20 \\
=56700\end{array}$ & sıva tecdîdi \\
\hline 95 & $2 \mathbf{a}$ & $\begin{array}{l}\text { Mescid-i Aksâ'ya muttasıl } \\
\text { Hazreti Ömer } \\
\text { radiyallahu anh Câmi-i Şerîfi } \\
\text { derûnunda sıva } \\
\text { tecdîdi. }\end{array}$ & & 41 & 20 & $\begin{array}{l}820 \mathrm{x} \text { fi } \\
30= \\
24600\end{array}$ & siva tecdîdi \\
\hline 96 & $2 \mathbf{a}$ & $\begin{array}{l}\text { Mahal-i mübâreke buz cam } \\
\text { tecdîdi. }\end{array}$ & 3 & $\begin{array}{l}1,5 \\
\text { kadden }\end{array}$ & 1 & $\begin{array}{l}\times \text { xi } \\
240=96 \\
0 \\
4 \text { buçuk } \\
\times 240= \\
1080\end{array}$ & $\begin{array}{l}\text { buz cam } \\
\text { tecdîdi }\end{array}$ \\
\hline 97 & $2 \mathbf{a}$ & $\begin{array}{l}\text { Câmi-i Şerîfin etrafi birûn } \\
\text { dıvarlarında } \\
\text { horasanlı kireçli dûr. }\end{array}$ & & 36 & 4 & $\begin{array}{l}104 \times \text { fi } \\
60=624 \\
0\end{array}$ & dûr \\
\hline 98 & $2 \mathbf{a}$ & \begin{tabular}{lcr} 
Cami-i & şerifin & \multicolumn{2}{c}{ sakfında } \\
horasanlı ve kireçli & ve \\
kalemkârî sıva tecdîdi. &
\end{tabular} & & 20 & 8 & $\begin{array}{l}160 \times \mathrm{xi} \\
20= \\
3200\end{array}$ & siva tecdîdi \\
\hline 99 & $\mathbf{2 a}$ & $\begin{array}{l}\text { Seyyidinâ Davud } \\
\text { aleyhisselam } \\
\text { Efendimizin mihrabında ve } \\
\text { kubbelerinde } \\
\text { ketenli ve kireçli beyaz sıva } \\
\text { tecdîdi. }\end{array}$ & & 12 & 10 & $\begin{array}{l}120 \times \text { fi } \\
20= \\
2400\end{array}$ & siva tecdîdi \\
\hline $\begin{array}{l}10 \\
0\end{array}$ & $2 \mathbf{a}$ & $\begin{array}{l}\text { Kubbe-i şerîfin sakfında küllü } \\
\text { ve kireçli ve } \\
\text { kalemkârî sıva tecdîdi. }\end{array}$ & & 10 & 10 & $\begin{array}{l}100 \times \mathrm{xi} \\
20= \\
2000\end{array}$ & sıva tecdîdi \\
\hline $\begin{array}{l}10 \\
1\end{array}$ & $2 \mathbf{a}$ & $\begin{array}{l}\text { Hanbelî Câmi-i Şerîfinde } \\
\text { ketenli ve kireçli } \\
\text { beyaz sıva tecdîdi. }\end{array}$ & & 50 & 14 & $\begin{array}{l}700 \times \mathrm{fi} \\
20= \\
14000\end{array}$ & siva tecdîdi \\
\hline $\begin{array}{l}10 \\
2\end{array}$ & $2 \mathbf{a}$ & $\begin{array}{l}\text { Mahal-i mübârekenin üzerinde } \\
\text { küllü ve } \\
\text { kireçli ve kalemkârî sıva } \\
\quad \text { tecdîdi. }\end{array}$ & & 50 & 12 & $\begin{array}{l}700 \times \mathrm{fi} \\
30 \\
=21000\end{array}$ & siva tecdîdi \\
\hline $\begin{array}{l}10 \\
3\end{array}$ & $2 \mathbf{a}$ & $\begin{array}{l}\text { Seyyidinâ İsa Nebi } \\
\text { aleyhisselam } \\
\text { efendimizin } \\
\text { mehdi } \begin{array}{l}\text { şerifleri mukabilinde } \\
\text { kubbelerde }\end{array} \\
\text { ketenli } \begin{array}{l}\text { ve kireçli beyaz sıva } \\
\text { tecdîdi. }\end{array}\end{array}$ & & 24 & 14 & $\begin{array}{l}336 \mathrm{x} \mathrm{fi} \\
20 \\
=6720\end{array}$ & siva tecdîdi \\
\hline $\begin{array}{l}10 \\
4\end{array}$ & $2 \mathbf{a}$ & $\begin{array}{l}\text { Mahal-i mübârekeye Karaağaç } \\
\text { kabuğundan neccarkârî kapu } \\
\text { ma‘a kufl ve miftâh. }\end{array}$ & & $\begin{array}{l}2 \\
\text { kadden }\end{array}$ & 1 & $\begin{array}{l}2 \times \mathrm{fi} \\
600\end{array}$ & $\begin{array}{l}\text { kapu ma'a } \\
\text { kufl ve } \\
\text { miftâh }\end{array}$ \\
\hline $\begin{array}{l}10 \\
5\end{array}$ & $\mathbf{2 b}$ & $\mathrm{Bu}$ mahalde tel kafes tecdîdi. & & $\begin{array}{l}1,5 \\
\text { kadden }\end{array}$ & 1 & $\begin{array}{l}1 \\
\text { buçuk. } \\
180\end{array}$ & $\begin{array}{l}\text { tel kafes } \\
\text { tecdîdi }\end{array}$ \\
\hline $\begin{array}{l}10 \\
6\end{array}$ & $\mathbf{2 b}$ & $\begin{array}{l}\text { Mâliki Câmi-i Şerîfin yesârı } \\
\text { tarafında ketenli } \\
\text { ve kireçli ve taş kesme sıva } \\
\text { tecdîdi. }\end{array}$ & & 80 & 8 & $\begin{array}{l}640 \times \mathrm{fi} \\
20 \\
=12800\end{array}$ & siva tecdîdi \\
\hline $\begin{array}{l}10 \\
7\end{array}$ & $2 \mathbf{b}$ & $\begin{array}{l}\text { Câmi-i } \begin{array}{l}\text { Şerîfin derûnunda } \\
\text { ketenli ve kireçli }\end{array} \\
\text { beyaz sıva tecdîdi. }\end{array}$ & & 184 & 10 & $\begin{array}{l}1840 x \\
\text { fi } 20 \\
=36800\end{array}$ & siva tecdîdi \\
\hline $\begin{array}{l}10 \\
8\end{array}$ & $\mathbf{2 b}$ & $\begin{array}{l}\text { mahalde kavsler ve } \\
\text { kubbelerinde ketenli } \\
\text { ve kireçli beyaz sıva tecdîdi. }\end{array}$ & & 12 & 6 & $\begin{array}{l}72 \times \mathrm{fi} \\
20=144 \\
0\end{array}$ & sıva tecdîdi \\
\hline
\end{tabular}




\begin{tabular}{|c|c|c|c|c|c|c|c|}
\hline $\begin{array}{l}10 \\
9\end{array}$ & $2 \mathrm{~b}$ & $\begin{array}{l}\text { Câmi-i Şerîfin sakfinda küllü } \\
\text { ve kireçli ve } \\
\text { kalemkârî sıva tecdîdi. }\end{array}$ & & 45 & 12 & $\begin{array}{l}540 \times \mathrm{fi} \\
30 \\
=16200\end{array}$ & sıva tecdîdi \\
\hline $\begin{array}{l}11 \\
0\end{array}$ & $2 b$ & $\begin{array}{l}\mathrm{Bu} \text { mahalde sakfi mezbûrda } \\
\text { cedîd kurşun } \\
\text { vaz'1. }\end{array}$ & 210 & & & $\begin{array}{l}6300 x \\
\text { fi } \\
6=3780 \\
0 \\
\end{array}$ & $\begin{array}{l}\text { cedid } \\
\text { kurşun } \\
\text { vaz'1 }^{6}\end{array}$ \\
\hline $\begin{array}{l}11 \\
1\end{array}$ & $2 b$ & $\begin{array}{l}\mathrm{Bu} \text { mahalde pencere } \\
\text { kanatlarında neccarkârî ta'mîr. }\end{array}$ & 10 & 2 & 1,5 & $\begin{array}{l}30 \times \mathrm{fi} \\
60=180 \\
0\end{array}$ & $\begin{array}{l}\text { neccarkârî } \\
\text { ta‘mîr }\end{array}$ \\
\hline $\begin{array}{l}11 \\
2\end{array}$ & $2 b$ & $\begin{array}{l}\text { Yine mahalde Orta tahta Cami- } \\
\text { i ve timur tel } \\
\text { örmeli kafes ve cam ve çercube } \\
\text { tecdîdi. }\end{array}$ & 10 & 1,5 & 1 & $\begin{array}{l}15 \times \mathrm{fi} \\
120 \\
=1800\end{array}$ & $\begin{array}{l}\text { kafes ve } \\
\text { cam ve } \\
\text { çercube } \\
\text { tecdîdi }\end{array}$ \\
\hline $\begin{array}{l}11 \\
3\end{array}$ & $2 b$ & $\begin{array}{ll}\text { Câmi-i } & \text { Şerîfin mukabilinde } \\
& \text { kubbe küllü ve } \\
\text { kireçli } & \text { ve kalemkârî sıva } \\
& \text { tecdîdi. }\end{array}$ & & 6 & 6 & $\begin{array}{l}36 \times \mathrm{fi} \\
30=108 \\
0\end{array}$ & sıva tecdîdi \\
\hline $\begin{array}{l}11 \\
4\end{array}$ & $2 b$ & $\begin{array}{l}\text { Burak halkası ve Câmi-i Şerîf } \\
\text { derûnlarında ketenli ve kireçli } \\
\text { sıva tecdîdi. }\end{array}$ & & 50 & 10 & $\begin{array}{l}500 \times \mathrm{fi} \\
20=100 \\
0\end{array}$ & sıva tecdîdi \\
\hline $\begin{array}{l}11 \\
5\end{array}$ & $2 b$ & $\begin{array}{l}\text { Câmi-i Şerîfin ve kavslerin } \\
\text { sakflarında küllü ve kireçli ve } \\
\text { kalem kârî sıva tecdîdi. }\end{array}$ & & 90 & 12 & $\begin{array}{l}1080 x \\
\text { fi } 20 \\
=21600\end{array}$ & sıva tecdîdi \\
\hline $\begin{array}{l}11 \\
6\end{array}$ & $2 b$ & $\begin{array}{l}\text { Bu mahalde kanatlık } \\
\text { tahtasından ve küllü çiftesinden } \\
\text { kuşaklı pencere ma'a kapu. }\end{array}$ & 3 & & & $\begin{array}{l}10 \times \text { fi } \\
60 \\
=600\end{array}$ & $\begin{array}{l}\text { pencere } \\
\text { ma'a kapu }\end{array}$ \\
\hline $\begin{array}{l}11 \\
7\end{array}$ & & $\begin{array}{l}\text { Mescid-i Aksâ kurbunda Kadı } \\
\text { kubbesi derûnunda ve sakfında } \\
\text { küllü ve kireçli sıva tecdîdi. }\end{array}$ & & 8 & 6 & $\begin{array}{l}48 \times \mathrm{fi} \\
30= \\
1440\end{array}$ & siva tecdîdi \\
\hline $\begin{array}{l}11 \\
8\end{array}$ & $2 b$ & $\begin{array}{l}\text { Üç adet minarelerde saçak ve } \\
\text { badanalı ve külahı horasanlı ve } \\
\text { kireçli sıva tecdîdi. }\end{array}$ & 3 & 25 & 12 & $\begin{array}{l}900 \times \text { fi } \\
120= \\
108000\end{array}$ & sıva tecdîdi \\
\hline $\begin{array}{l}11 \\
9\end{array}$ & $2 b$ & $\begin{array}{l}\text { Bab-1 .... ittisalinde minarenin } \\
\text { lik tecdîdi. }\end{array}$ & & $\begin{array}{l}4 \\
\text { kadden }\end{array}$ & $\begin{array}{l}12 \\
\text { dûren }\end{array}$ & $\begin{array}{l}48 \times \text { fi } \\
840=40 \\
320 \\
\end{array}$ & lik tecdîdi \\
\hline $\begin{array}{l}12 \\
0\end{array}$ & $2 b$ & $\begin{array}{l}\text { Minare-i merkumun seranlı ve } \\
\text { hazine koğuşundan döşemeli ve } \\
\text { Rumili öğürgesinden girişmeli } \\
\text { ve kurşun tecdîdi. }\end{array}$ & & $\begin{array}{l}12 \\
\text { kadden }\end{array}$ & 6 dûren & $\begin{array}{l}72 \times \text { fi } \\
1200=8 \\
6400\end{array}$ & $\begin{array}{l}\text { kurşun } \\
\text { tecdîdi }\end{array}$ \\
\hline $\begin{array}{l}12 \\
1\end{array}$ & $2 b$ & $\begin{array}{l}\text { Minare-i mezbûrun şerefesi } \\
\text { üzerinde Rumili öğürgesinden } \\
\text { saçak ve parmaklık tecdîd. }\end{array}$ & & 16 & 1,5 & $\begin{array}{l}24 \mathrm{x} \text { fi } \\
240 \\
=57600\end{array}$ & $\begin{array}{l}\text { saçak ve } \\
\text { parmaklık } \\
\text { tecdîd }\end{array}$ \\
\hline $\begin{array}{l}12 \\
2\end{array}$ & $2 \mathrm{~b}$ & $\begin{array}{l}\text { Minare-i mezbûre bi'l-cümle } \\
\text { badana. }\end{array}$ & & & & $\begin{array}{l}300 \times \text { fi } \\
300 \\
=9000\end{array}$ & badana \\
\hline $\begin{array}{l}12 \\
3\end{array}$ & $2 b$ & $\begin{array}{l}\text { Seyyidinâ Musa Aleyhisselam } \\
\text { Efendimizin kubbesi etrafi } \\
\text { dıvarlarında ketenli ve kireçli } \\
\text { ve taş kesme sıva tecdîd. }\end{array}$ & & 36 & 8 & $\begin{array}{l}304 \times \text { fi } \\
20= \\
1080\end{array}$ & sıva tecdîd \\
\hline $\begin{array}{l}12 \\
4\end{array}$ & $2 b$ & $\begin{array}{l}\text { Bu mahalde pencere ve kapu } \\
\text { müremmimat1. }\end{array}$ & 6 & 2 & 1,5 & $\begin{array}{l}3 \times \text { fi } \\
60- \\
\text { Adet } \\
18 . \\
=1080 \\
\end{array}$ & $\begin{array}{l}\text { pencere ve } \\
\text { kapu } \\
\text { müremmim } \\
\text { at1 }\end{array}$ \\
\hline $\begin{array}{l}12 \\
5\end{array}$ & $2 b$ & $\begin{array}{l}\text { Mescid-i Aksâ } \text { ittisalinde } \\
\text { Fârisiyye Medresesi dıvarında } \\
\text { ketenli ve kireçli beyaz sıva } \\
\text { tecdîdi. }\end{array}$ & & 39 & 4,5 & $\begin{array}{l}175 \\
\text { buçuk } x \\
\text { fi } 20 \\
=3510\end{array}$ & sıva tecdîdi \\
\hline $\begin{array}{l}12 \\
6\end{array}$ & $2 b$ & $\begin{array}{l}\text { Medrese-i Mezbûrun sakfında } \\
\text { küllü ve kireçli ve kalemkârî }\end{array}$ & & 34 & 21 & $\begin{array}{l}714 \times \text { fi } \\
20\end{array}$ & sıva tecdîdi \\
\hline
\end{tabular}




\begin{tabular}{|c|c|c|c|c|c|c|c|}
\hline & & siva tecdîdi. & & & & $=21420$ & \\
\hline $\begin{array}{l}12 \\
7\end{array}$ & $\mathbf{2 b}$ & $\begin{array}{l}\text { Merhum Kayd Bey Cami-i } \\
\text { şerifi ba-emr-i âli hedm kargir } \\
\text { som ayak tecdîdi. }\end{array}$ & & $\begin{array}{l}12 \\
\text { kadden }\end{array}$ & $\begin{array}{l}3,5- \\
2,5\end{array}$ & $\begin{array}{l}105 \times \text { fi } \\
720 \\
=75600\end{array}$ & $\begin{array}{l}\text { som ayak } \\
\text { tecdîdi }\end{array}$ \\
\hline $\begin{array}{l}12 \\
8\end{array}$ & 2b & $\begin{array}{l}\text { Ayak-1 mezbûrun kavs-i } \\
\text { selasesi tecdîdi. }\end{array}$ & & 12 & 1,5 & $\begin{array}{l}30 \times \mathrm{fi} \\
840 \\
=25200\end{array}$ & $\begin{array}{l}\text { kavs-i } \\
\text { selasesi } \\
\text { tecdîdi }\end{array}$ \\
\hline $\begin{array}{l}12 \\
9\end{array}$ & $2 \mathbf{2 b}$ & $\begin{array}{l}\text { Mahal-i mübâreke kargir divar } \\
\text { tecdîdi. }\end{array}$ & & 60 & 2,5 & $\begin{array}{l}150 \times \text { fi } \\
180 \\
=27000\end{array}$ & $\begin{array}{l}\text { kargir divar } \\
\text { tecdîdi }\end{array}$ \\
\hline $\begin{array}{l}13 \\
0\end{array}$ & $2 \mathbf{b}$ & $\begin{array}{l}\text { Cami-i şerifin döşeme } \\
\text { mahallinde kireçli ve horasanlı } \\
\text { ve kalemkârî sıva tecdîdi. }\end{array}$ & & 23 & 18 & $\begin{array}{l}410 \times \mathrm{xi} \\
120 \\
=49680\end{array}$ & siva tecdîdi \\
\hline $\begin{array}{l}13 \\
1\end{array}$ & $2 \mathbf{2 b}$ & $\begin{array}{l}\text { Mahal-i mübârekenin sakfinda } \\
\text { orta câbeden makaslı ve Rumili } \\
\text { öğürgesinden kuşaklı ve kilimli } \\
\text { çiftesinden mertekli ve kalyos } \\
\text { kanatlığından kaplamalı ve } \\
\text { kireç ile sıvalı ve üzeri cedîd } \\
\text { kurşunlu sakf tecdîdi. }\end{array}$ & & 30 & 12 & $\begin{array}{l}360 \times \mathrm{fi} \\
180 \\
=64800\end{array}$ & sakf tecdîdi \\
\hline $\begin{array}{l}13 \\
2\end{array}$ & $2 \mathbf{b}$ & $\begin{array}{l}\text { Cami-i şerifin harem havlısı } \\
\text { döşeme mahallinde kireçli ve } \\
\text { horasanlı ve kalemkârî sıva } \\
\text { tecdîdi. }\end{array}$ & & 10 & 10 & $\begin{array}{l}100 \times \mathrm{fi} \\
20 \\
=2000\end{array}$ & siva tecdîdi \\
\hline $\begin{array}{l}13 \\
3\end{array}$ & $2 \mathbf{2 b}$ & $\begin{array}{l}\text { Câmi-i Şerîfin } \\
\text { kapusu ta'mîri. }\end{array}$ & & $\begin{array}{l}4 \\
\text { kadden }\end{array}$ & 2 & $\begin{array}{l}8 \times \text { fi } \\
120=96 \\
0\end{array}$ & \\
\hline $\begin{array}{l}13 \\
4\end{array}$ & $2 \mathbf{2 b}$ & Kayd Bey sebilinde derz. & & & & $\begin{array}{l}60 \times \text { fi } \\
60=360 \\
0\end{array}$ & derz \\
\hline $\begin{array}{l}13 \\
5\end{array}$ & $2 \mathbf{b}$ & $\begin{array}{l}\text { Kayd Bey Cami-i şerifin } \\
\text { tahtında Hanbeli Cami-i şerifde } \\
\text { kireçli ve ketenli beyaz siva } \\
\text { tecdîdi. }\end{array}$ & & 80 & 18 & $\begin{array}{l}1440 x \\
\text { fi } 20 \\
=28800\end{array}$ & siva tecdîdi \\
\hline $\begin{array}{l}13 \\
6\end{array}$ & $2 \mathbf{b}$ & $\begin{array}{l}\text { Bu mahalde kapu ve pencere ve } \\
\text { kanatları tecdîdi. }\end{array}$ & 3 & 3 & 1,5 & $\begin{array}{l}4 \text { buçuk } \\
x \text { fi } 60 \\
=270\end{array}$ & $\begin{array}{l}\text { kapu ve } \\
\text { pencere ve } \\
\text { kanatları } \\
\text { tecdîdi }\end{array}$ \\
\hline $\begin{array}{l}13 \\
7\end{array}$ & $2 \mathbf{2 b}$ & $\begin{array}{l}\text { Bu mahalde kitabhanede kireçli } \\
\text { ve ketenli beyaz sıva tecdîdi. }\end{array}$ & & 40 & 12 & $\begin{array}{l}480 \times \mathrm{x} \mathrm{fi} \\
20 \\
=9600\end{array}$ & sıva tecdîdi \\
\hline $\begin{array}{l}13 \\
8\end{array}$ & $2 \mathbf{b}$ & $\begin{array}{l}\mathrm{Bu} \text { mahalde kapulara ve } \\
\text { pencerelere cevzi boya tecdîdi. }\end{array}$ & 4 & 3 & 2 & $\begin{array}{l}24 \mathrm{x} \text { fi } \\
30=720\end{array}$ & $\begin{array}{l}\text { boya } \\
\text { tecdîdi }\end{array}$ \\
\hline $\begin{array}{l}13 \\
9\end{array}$ & $2 \mathbf{b}$ & Bu mahalde buz cam tecdîdi. & 3 & 2 & 1,5 & $\begin{array}{l}9 \times \mathrm{x} \mathrm{fi} \\
120 \\
=1080\end{array}$ & $\begin{array}{l}\text { buz cam } \\
\text { tecdîdi }\end{array}$ \\
\hline $\begin{array}{l}14 \\
0\end{array}$ & $2 \mathbf{b}$ & $\begin{array}{l}\text { Revak1 sâkin olduğu mahalde } \\
\text { ketenli ve kireçli beyaz sıva } \\
\text { tecdîdi. }\end{array}$ & & 54 & 15 & $\begin{array}{l}810 \times \mathrm{fi} \\
20 \\
=16200\end{array}$ & siva tecdîdi \\
\hline $\begin{array}{l}14 \\
1\end{array}$ & $2 \mathbf{b}$ & $\begin{array}{l}\text { Su hazinesi etrafinda ketenli ve } \\
\text { kireçli beyaz sıva tecdîdi. }\end{array}$ & & 16 & 6 & $\begin{array}{l}96 \times \mathrm{fi} \\
20=192 \\
0\end{array}$ & siva tecdîdi \\
\hline $\begin{array}{l}14 \\
2\end{array}$ & $2 \mathbf{2 b}$ & $\begin{array}{l}\text { Su hazinesi ittisalinde horasanlı } \\
\text { kireçli ve rağınlı ve cilalı sıva } \\
\text { havuz tecdîdi. }\end{array}$ & & 10 & $\begin{array}{l}10 \\
\text { kadden }\end{array}$ & $\begin{array}{l}100 \times \mathrm{x} \mathrm{fi} \\
120 \\
=12000\end{array}$ & $\begin{array}{l}\text { havuz } \\
\text { tecdîdi }\end{array}$ \\
\hline $\begin{array}{l}14 \\
3\end{array}$ & $2 \mathbf{2 b}$ & $\begin{array}{ll}\text { Osmaniye } & \text { Medresesi } \\
\text { derûnunda ketenli ve kireçli } \\
\text { siva tecdîdi. }\end{array}$ & & & & $\begin{array}{l}100 \times \text { fi } \\
20=200 \\
0\end{array}$ & siva tecdîdi \\
\hline $\begin{array}{l}14 \\
4\end{array}$ & $2 \mathbf{2 b}$ & $\begin{array}{l}\text { Bu mahalde hazine koğuşundan } \\
\text { ve kilimli çiftesinden kuşaklı } \\
\text { ve neccarkârî kalem } 1 \text {. }\end{array}$ & & $\begin{array}{l}2,5 \\
\text { kadden }\end{array}$ & 1 & $4=960$ & $\begin{array}{l}\text { neccarkârî } \\
\text { kalem } 1\end{array}$ \\
\hline 14 & 2b & Harem-i Şerîfin taşra Bâb-1 & & 12 & 10 & $120 \times \mathrm{fi}$ & sıva tecdîdi \\
\hline
\end{tabular}




\begin{tabular}{|c|c|c|c|c|c|c|c|}
\hline 5 & & 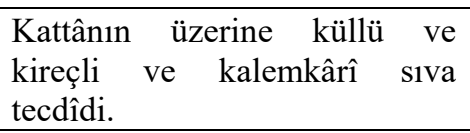 & & & & $\begin{array}{l}30=360 \\
0\end{array}$ & \\
\hline $\begin{array}{l}14 \\
6\end{array}$ & $\mathbf{2 b}$ & $\begin{array}{l}\text { Sebil-i Şağlan } \\
\text { ketenli ve kireçli } \\
\text { sıva tecdîdi. }\end{array}$ & & & & $\begin{array}{l}100 \times \text { fi } \\
20=200 \\
0\end{array}$ & siva tecdîdi \\
\hline $\begin{array}{l}14 \\
7\end{array}$ & $\mathbf{2 b}$ & $\begin{array}{l}\text { Seyyidinâ Süleyman Nebi } \\
\text { aleyhisselam Efendimizin } \\
\text { burca sahratullah üzerine bina } \\
\text { eylediği kubbenin derûn } \\
\text { birûnunda kireçli ve horasanlı } \\
\text { ve ketenli siva tecdîdi. }\end{array}$ & & & & $\begin{array}{l}168 \times \mathrm{fi} \\
40 \\
=6720\end{array}$ & siva tecdîdi \\
\hline $\begin{array}{l}14 \\
8\end{array}$ & $\mathbf{2 b}$ & $\begin{array}{l}\text { Bu mahalde hazine koğuşundan } \\
\text { ve kilimli çiftesinden kuşaklı } \\
\text { neccarkârî kapu. }\end{array}$ & 1 & 3 & 1,5 & $\begin{array}{l}\begin{array}{l}4 \text { buçuk } \\
=960\end{array} \\
\end{array}$ & $\begin{array}{l}\text { neccarkârî } \\
\text { kapu }\end{array}$ \\
\hline $\begin{array}{l}14 \\
9\end{array}$ & $\mathbf{2 b}$ & $\begin{array}{l}\text { Bu mahal-i mübârekenin } \\
\text { sakfinda horasanlı ve kireçli ve } \\
\text { kalemkârî sıva tecdîdi. }\end{array}$ & & $\begin{array}{l}2 \\
\text { kadden }\end{array}$ & $\begin{array}{l}20 \\
\text { dûren }\end{array}$ & $\begin{array}{l}40 x \text { fi } \\
20=800\end{array}$ & sıva tecdîdi \\
\hline $\begin{array}{l}15 \\
0\end{array}$ & $\mathbf{2 b}$ & Bu mahalde buz camı tecdîdi. & 8 & 1 & 18 & $\begin{array}{l}5 \times \mathrm{fi} \\
120=60 \\
0\end{array}$ & $\begin{array}{l}\text { buz camı } \\
\text { tecdîdi }\end{array}$ \\
\hline $\begin{array}{l}15 \\
1\end{array}$ & $\mathbf{2 b}$ & $\begin{array}{l}\text { Seyyidinâ Süleyman Nebi } \\
\text { aleyhisselam Efendimizin } \\
\text { kürsi-i şeriflerinde ketenli ve } \\
\text { kireçli beyaz sıva tecdîdi. }\end{array}$ & & 62 & 10 & $\begin{array}{l}620 \times \text { fi } \\
20= \\
12400\end{array}$ & sıva tecdîdi \\
\hline $\begin{array}{l}15 \\
2\end{array}$ & $\mathbf{2 b}$ & $\begin{array}{l}\text { Bu mahal-i mübârekede geçme } \\
\text { hola camı. }\end{array}$ & 4 & 1,5 & 1 & $\begin{array}{l}6 \times \mathrm{xfi} \\
120=72 \\
0\end{array}$ & $\begin{array}{l}\text { geçme hola } \\
\text { camı }\end{array}$ \\
\hline $\begin{array}{l}15 \\
3\end{array}$ & $\mathbf{3 a}$ & $\begin{array}{l}\text { Mahal-i mübârekenin sakfi } \\
\text { üzerinde horasanlı ve kireçli ve } \\
\text { cilalı sıva tecdîdi. }\end{array}$ & & 20 & 16 & $\begin{array}{l}320 \times \mathrm{fi} \\
40 \\
=12800\end{array}$ & siva tecdîdi \\
\hline $\begin{array}{l}15 \\
4\end{array}$ & $\mathbf{3 a}$ & $\begin{array}{l}\text { Sitti Meryem Validemizin } \\
\text { mihrabı sakfında kireçli ve } \\
\text { küllü ve cilalı sıva tecdîdi. }\end{array}$ & & 10 & 4 & $\begin{array}{l}40 \times \mathrm{fi} \\
40=160 \\
0\end{array}$ & siva tecdîdi \\
\hline $\begin{array}{l}15 \\
5\end{array}$ & $\mathbf{3 a}$ & $\begin{array}{l}\text { Sahratullahü'l-müşerrefenin } \\
\text { sahnı fevkinde ve tahtında } \\
\text { mataru'l-ma'i hıfzı içün } \\
\text { horasanlı ve kireçli ve reğinli } \\
\text { ve cilalı bi'rü'l-mâ. }\end{array}$ & 11 & & & $\begin{array}{l}7287 x \\
\text { fi } 50= \\
364350\end{array}$ & $\begin{array}{l}\text { mataru'l- } \\
\text { ma'i hıfzi }\end{array}$ \\
\hline $\begin{array}{l}15 \\
6\end{array}$ & $\mathbf{3 a}$ & $\begin{array}{l}\text { Sahın fevkinde ve tahtında } \\
\text { tabanları onbeş arşundan } \\
\text { kebirinden ve sütunlar orta } \\
\text { câbeden ve ferşleri on iki } \\
\text { arşından çiftesinden asmalık } \\
\text { tecdîdi. }\end{array}$ & & & & $\begin{array}{l}884 \times \mathrm{fi} \\
60 \\
=53040\end{array}$ & $\begin{array}{l}\text { asmalık } \\
\text { tecdîdi }\end{array}$ \\
\hline $\begin{array}{l}15 \\
7\end{array}$ & $3 \mathbf{a}$ & $\begin{array}{l}\text { Sahın fevkinde küfeli misillu } \\
\text { döşemelerinde ba'zen fena } \\
\text { bezir bulmağla mahallerinden } \\
\text { kalkub yüzü işlemeli ve } \\
\text { gönyeden çıma kenarlı küfeli } \\
\text { taşından döşeme tecdîdi. }\end{array}$ & & & & $\begin{array}{l}4270 x \\
\text { fi } 90 \\
=38430 \\
0\end{array}$ & $\begin{array}{l}\text { taş döșeme } \\
\text { tecdîdi }\end{array}$ \\
\hline $\begin{array}{l}15 \\
8\end{array}$ & $\mathbf{3 a}$ & $\begin{array}{l}\text { Yine sahn-1 merkumun ba'zen } \\
\text { mahalleri nebatat kesretinden } \\
\text { fena bulmağla mahallinden } \\
\text { kalkub tathir olundukda yine } \\
\text { mahallerine kireç harçlı ve } \\
\text { vaz'1 döşeme taş. }\end{array}$ & & & & $\begin{array}{l}14780 x \\
\text { fi } 30 \\
=44340 \\
0\end{array}$ & $\begin{array}{l}\text { vaz'1 }^{\prime} \text { döşeme taş }\end{array}$ \\
\hline 15 & 3a & Fahriye $\quad$ Câmi-i & & 20 & 22 & $440 \mathrm{x} \mathrm{fi}$ & siva \\
\hline
\end{tabular}




\begin{tabular}{|c|c|c|c|c|c|c|c|}
\hline 9 & & $\begin{array}{l}\text { derûnunda ketenli ve kireçli } \\
\text { beyaz sıva. }\end{array}$ & & & & $\begin{array}{l}20=880 \\
0\end{array}$ & \\
\hline $\begin{array}{l}16 \\
0\end{array}$ & $\mathbf{3 a}$ & $\begin{array}{l}\mathrm{Bu} \text { mahalde tekne kubbe } \\
\text { tecdîdi kargir. }\end{array}$ & & 10 & 10 & $\begin{array}{l}100 \times \text { fi } \\
40=400 \\
0\end{array}$ & $\begin{array}{l}\text { kargir } \\
\text { kubbe } \\
\text { tecdîdi }\end{array}$ \\
\hline $\begin{array}{l}16 \\
1\end{array}$ & $3 \mathbf{a}$ & $\begin{array}{l}\text { Bu mahallin sakfında rıhtım taş } \\
\text { döşemeli ve kireçli ve küllü ve } \\
\text { kalemkârî sıva tecdîdi. . }\end{array}$ & & 22 & 12 & $\begin{array}{l}262 \times \text { fi } \\
30=786 \\
0\end{array}$ & sıva tecdîdi \\
\hline $\begin{array}{l}16 \\
2\end{array}$ & $\mathbf{3 a}$ & $\begin{array}{l}\mathrm{Bu} \text { mahalde kanatlık } \\
\text { tahtasından dolab tecdîdi . }\end{array}$ & & $\begin{array}{l}2 \\
\text { Kadden }\end{array}$ & 1,5 & 360 & $\begin{array}{l}\text { dolab } \\
\text { tecdîdi }\end{array}$ \\
\hline $\begin{array}{l}16 \\
3\end{array}$ & $\mathbf{3 a}$ & $\begin{array}{l}\text { Bu mahalde kargir dıvar bozine } \\
\text { kireçli ve horasanlı derz. }\end{array}$ & & 40 & 4 & $\begin{array}{l}160 \times \text { fi } \\
30=480 \\
0\end{array}$ & derz \\
\hline $\begin{array}{l}16 \\
4\end{array}$ & $3 \mathbf{a}$ & $\begin{array}{l}\text { Bab-1 Sitti Meryem sakfinda } \\
\text { kireçli ve küllü ve cilalı } \\
\text { kalemkârî sıva tecdîdi. }\end{array}$ & & 16 & 12 & $\begin{array}{l}192 \times \text { fi } \\
30=576 \\
0\end{array}$ & sıva tecdîdi \\
\hline $\begin{array}{l}16 \\
5\end{array}$ & $3 \mathbf{a}$ & $\begin{array}{lc}\text { Kudus-i } & \text { Şerifde vâki' bab-1 } \\
\text { hazreti } & \text { Halilü’r-rahman } \\
\text { sakfinda kireçli ve küllü ve } \\
\text { cilalı kalemkârî sıva tecdîdi. }\end{array}$ & & 16 & 16 & $\begin{array}{l}256 \times \text { fi } \\
30=768 \\
0\end{array}$ & siva tecdîdi \\
\hline \multicolumn{8}{|c|}{$\begin{array}{r}\text { Cem'an Yekün 65493,80 } \\
\text { Cem'an 54411,5 }\end{array}$} \\
\hline \multicolumn{8}{|c|}{$\begin{array}{l}\text { "Seyyidinâ Halilü’r-rahman Aleyhisselam Efendimizin Makam-ı şeriflerinin Keşif Defter-i } \\
\text { müfredatıdır." }\end{array}$} \\
\hline 1 & $3 \mathbf{a}$ & \begin{tabular}{lrr} 
Hazreti & \multicolumn{2}{r}{ Halilü’r-rahman } \\
Efendimizin Makam-1 şerifleri \\
ittisalinde vâki' Cami-i & şerif \\
derûnunda mihrab-1 & şerifin \\
yemin ve yesarında sure-i & surn \\
İbrahim Ayet-i kerimelerde \\
tecdîd boya.
\end{tabular} & & 130 & 18 & $\begin{array}{l}97 \times \text { fi } \\
120 \\
=11640\end{array}$ & tecdîd boya \\
\hline 2 & $\mathbf{3 a}$ & $\begin{array}{l}\text { Mahal-i mübârekenin yemin ve } \\
\text { yesarında kavs ve kubbelerinde } \\
\text { ketenli ve kireçli beyaz sıva } \\
\text { tecdîdi. }\end{array}$ & & 30 & 22 & $\begin{array}{l}660 \times \text { fi } \\
20 \\
=13200\end{array}$ & sıva tecdîdi \\
\hline 3 & $3 \mathbf{a}$ & $\begin{array}{l}\text { Mezkûr kemer ve kubbelerin } \\
\text { kafes tahtası tahtında bezir. }\end{array}$ & & 60 & 12 & $\begin{array}{c}720 \times \mathrm{fi} \\
\quad 4 \\
=2840\end{array}$ & bezir \\
\hline 4 & $\mathbf{3 a}$ & $\begin{array}{lcr}\text { Cami-i şerifin } & \text { derûnunda } \\
\text { Seyyidinâ } & \text { İshak Nebiyyü } \\
\text { aleyhisselam efendimizin ve } \\
\text { zevcesi } & \text { Sitti Rebka validemizin } \\
\text { merkad-1 şeriflerinde badana. }\end{array}$ & & 50 & 5 & $\begin{array}{l}250 \times \text { fi } \\
4 \\
=1000\end{array}$ & badana \\
\hline 5 & $\mathbf{3 a}$ & $\begin{array}{l}\text { Cami-i şerifinin asat kubbesinde } \\
\text { badana. }\end{array}$ & & 30 & 18 & $\begin{array}{l}540 \times \mathrm{fi} \\
4 \\
=2160\end{array}$ & badana \\
\hline 6 & $3 \mathbf{a}$ & $\begin{array}{l}\text { Merkad-1 şeriflerin pencere } \\
\text { kanatlarında elvan boya tecdîdi. }\end{array}$ & 4 & 1,5 & 1 & $\begin{array}{l}6 \mathrm{x} \text { fi } \\
60=360\end{array}$ & boya tecdîdi \\
\hline 7 & $3 \mathbf{a}$ & $\begin{array}{l}\text { Merkad-1 şerifin kapularına } \\
\text { elvan boya tecdîdi }\end{array}$ & 2 & 2 & 1 & $\begin{array}{l}4 \times \text { fi } \\
60=240\end{array}$ & boya tecdîdi \\
\hline 8 & $3 \mathbf{a}$ & $\begin{array}{l}\text { Mahfel-i şerifin mermer kafes } \\
\text { tahtalarında oyma rumi nakış } \\
\text { üzerlerine elvan boya tecdîdi. }\end{array}$ & & & & $\begin{array}{l}22 \\
\text { buçuk } x \\
\text { fi } \\
60=135 \\
0\end{array}$ & boya tecdîdi \\
\hline 9 & $3 \mathbf{a}$ & $\begin{array}{l}\text { Cami-i şerifin pencerelerine cam } \\
\text { dıvar tecdîdi. }\end{array}$ & 3 & 2 & 3 & $\begin{array}{l}18 \times \text { fi } \\
480 \\
=8640\end{array}$ & $\begin{array}{l}\text { cam divar } \\
\text { tecdîdi }\end{array}$ \\
\hline
\end{tabular}




\begin{tabular}{|c|c|c|c|c|c|c|c|c|}
\hline 10 & $\mathbf{3 a}$ & $\begin{array}{l}\text { Gar-1 şerifin ittisalinde hazine } \\
\text { koğuşundan ve } \\
\text { öğürgesinden kuşaklı ve elvan } \\
\text { boyalı neccar kârî bölme zar } \\
\text { tecdîdi. }\end{array}$ & & 20 & 2,5 & & $\begin{array}{l}50 \mathrm{x} \text { fi } \\
120 \\
=6000\end{array}$ & $\begin{array}{l}\text { neccarkârî } \\
\text { bölme zar } \\
\text { tecdîdi }\end{array}$ \\
\hline 11 & $\mathbf{3 a}$ & $\begin{array}{l}\text { Gar-1 şerif kubbesi ve hatib } \\
\text { hücresi kubbelerinde ayet-i } \\
\text { kerimelerde boya tecdîdi. }\end{array}$ & & & & & $\begin{array}{l}20 \times \mathrm{fi} \\
60=120 \\
0\end{array}$ & boya tecdîdi \\
\hline 12 & $\mathbf{3 a}$ & $\begin{array}{l}\text { Seyyidinâ Halilü'r-rahman } \\
\text { Aleyhisselam Efendimizin ve } \\
\text { zevcesi Hazreti Sitti Sâre } \\
\text { validemizin payeleri üzerlerinde } \\
\text { ayet-i kerimelere boya tecdîdi. }\end{array}$ & & 29 & 18 & & $\begin{array}{l}20 \\
\text { buçuk } x \\
\text { fi } 120 \\
=2460\end{array}$ & boya tecdîdi \\
\hline 13 & $\mathbf{3 a}$ & $\begin{array}{l}\text { Bu mahal-i mübârekede kubbede } \\
\text { Seyyidinâ Halilü'r-rahman } \\
\text { Efendimizin ve Sitti Sâre } \\
\text { validemizin beynlerindeki } \\
\text { kubbede siva tecdîdi. }\end{array}$ & & & & & $\begin{array}{l}54 \times \text { fi } \\
30 \\
=1620\end{array}$ & siva tecdîdi \\
\hline 14 & $\mathbf{3 a}$ & $\begin{array}{l}\text { Makam-1 mübârekenin bab-1 } \\
\text { şeriflerine ezma altunlu ve elvan } \\
\text { nakışlı boya tecdîdi. }\end{array}$ & & 2,5 & 1 & $\begin{array}{l}18- \\
9\end{array}$ & $\begin{array}{l}4 \mathrm{x} \text { fi } \\
600 \\
=2400\end{array}$ & boya tecdîdi \\
\hline 15 & $\mathbf{3 a}$ & $\begin{array}{l}\text { Seyyidinâ Aleyhisselam } \\
\text { Efendimizin harem havlısına } \\
\text { nezareti olan pencereye kabuluk } \\
\text { ceviz tahtasından geçme } \\
\text { çarcubeli ve biri rubu' üzerine } \\
\text { ayna cam çarcube tecdîdi. }\end{array}$ & & 3 & 3 & & $\begin{array}{l}9 \times \text { fi } \\
360 \\
=3240\end{array}$ & $\begin{array}{l}\text { ayna cam } \\
\text { çarcube } \\
\text { tecdîdi }\end{array}$ \\
\hline 16 & $\mathbf{3 a}$ & $\begin{array}{l}\text { Mahal-i mübârekenin mevcud } \\
\text { pencere kapanlarına ve tel örme } \\
\text { kafeslerinde elvan boya tecdîdi. }\end{array}$ & 4 & 3 & 3 & & $\begin{array}{l}34 \mathrm{x} \text { fi } \\
60=216 \\
0\end{array}$ & boya tecdîdi \\
\hline 17 & $\mathbf{3 a}$ & $\begin{array}{l}\text { Cami-i şerifin kebir kapuları } \\
\text { kitabelerine ve pervazlarına } \\
\text { elvan boya tecdîdi. }\end{array}$ & 2 & 4 & 2,5 & & $\begin{array}{l}20 \times \text { fi } \\
60= \\
1200\end{array}$ & boya tecdîdi \\
\hline 18 & $\mathbf{3 a}$ & $\begin{array}{l}\text { Seyyidina Yusuf Nebiyyu } \\
\text { Aleyhisselam efendimizin Cami- } \\
\text { i şerifinde mevcud mihrabda } \\
\text { keşan tecdîdi. }\end{array}$ & & & & & $\begin{array}{l}5 \times \mathrm{xfi} \\
720= \\
3600\end{array}$ & $\begin{array}{l}\text { mihrabda } \\
\text { keşan tecdîdi }\end{array}$ \\
\hline 19 & $\mathbf{3 a}$ & $\begin{array}{lr}\begin{array}{l}\text { Seyyidina } \\
\text { efendimizin } \\
\text { şeriflerinde sıva tecdîdi. }\end{array} & \text { Aleyhisselam } \\
\text { merkad-1 }\end{array}$ & & & & & $\begin{array}{l}36 \times \mathrm{fi} \\
30= \\
1080\end{array}$ & siva tecdîdi \\
\hline 20 & $\mathbf{3 a}$ & Mahal-i mübârekede badana. & & & & & $\begin{array}{l}100 \times \text { fi } \\
4=400\end{array}$ & badana \\
\hline 21 & $\mathbf{3 a}$ & 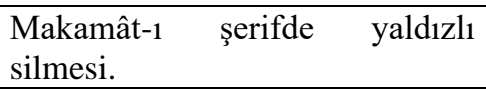 & & & & & & \\
\hline 22 & $\mathbf{3 b}$ & $\begin{array}{l}\text { Seyyidinâ Yusuf Nebi } \\
\text { Aleyhisselam efendimizin Cami- } \\
\text { i şerifinde sıva tecdîdi. }\end{array}$ & & 56 & 3 & & $\begin{array}{l}168 \times \text { fi } \\
30= \\
5040\end{array}$ & sıva tecdîdi \\
\hline 23 & 3b & Mahal-i şerifde boya. & & & & & $\begin{array}{l}220 \times \mathrm{fi} \\
4=880\end{array}$ & boya \\
\hline 24 & $\mathbf{3 b}$ & $\begin{array}{l}\text { Mahal-i mübârekelerin } \\
\text { kapılarına elvan boya tecdîdi. }\end{array}$ & 2 & 3 & 2 & & $\begin{array}{l}12 \times \mathrm{fi} \\
60=720\end{array}$ & boya tecdîdi \\
\hline 25 & $\mathbf{3 b}$ & $\begin{array}{l}\text { Mahal-i mübârekede ceviz } \\
\text { tahtasından çarçubeli ve yedi } \\
\text { rubu' üzerine ayna cam tecdîdi. }\end{array}$ & & 2 & 1 & & $\begin{array}{l}3 \text { buçuk } \\
\text { x fi } 310 \\
=1260\end{array}$ & $\begin{array}{l}\text { ayna cam } \\
\text { tecdîdi }\end{array}$ \\
\hline 26 & 3b & $\begin{array}{l}\text { Cami-i şerifin kebir kapıları } \\
\text { üzerlerinde ayet-i kerimelere } \\
\text { tecdîd boya. }\end{array}$ & & 26 & 18 & & $\begin{array}{l}19 \times \mathrm{fi} \\
120= \\
2280\end{array}$ & tecdîd boya \\
\hline
\end{tabular}




\begin{tabular}{|c|c|c|c|c|c|c|c|c|}
\hline 27 & $\mathbf{3 b}$ & $\begin{array}{l}\text { Seyyidinâ } \text { Yusuf } \\
\text { Aleyhisselam efendimizin Cami- } \\
\text { i şerifin sakfında tahtı kireçli } \\
\text { cedîd kurşun vaz'1 }\end{array}$ & & & & & $\begin{array}{l}60+12- \\
72 \\
6 \quad x \\
2160 \\
=12960\end{array}$ & $\begin{array}{l}\text { cedid kurşun } \\
\text { vaz'1 }\end{array}$ \\
\hline 28 & $\mathbf{3 b}$ & $\begin{array}{lcr}\text { Cami-i şerifin ittisalinde } & \text { son } \\
\text { cemaat } & \text { kubbelerinde } & \text { ve } \\
\text { kavislerinde sıa tecdîdi. } & \\
\end{array}$ & & 24 & 8 & & $\begin{array}{l}112 \times \text { fi } \\
30= \\
3360\end{array}$ & siva tecdîdi \\
\hline 29 & $\mathbf{3 b}$ & $\begin{array}{l}\text { Kezalik kubbeler ve kavislerde } \\
\text { bi'l-cümle badana. }\end{array}$ & & & & & $\begin{array}{l}396 \times \mathrm{fi} \\
4=1584\end{array}$ & badana \\
\hline 30 & $\mathbf{3 b}$ & $\begin{array}{l}\text { Harem-i şerif } \quad \text { havlısında } \\
\text { döşemelere dûr. }\end{array}$ & & & & & $\begin{array}{l}40 \times \text { fi } \\
60= \\
2400\end{array}$ & $\begin{array}{l}\text { döşemelere } \\
\text { dûr }\end{array}$ \\
\hline 31 & $\mathbf{3 b}$ & $\begin{array}{l}\text { Seyyidinâ } \\
\text { aleyhisselam } \\
\text { Makam-1 âbub aflilerinde pendimizin } \\
\text { üzerine çam tahtasından tavanlı } \\
\text { ve } \\
\text { Rumeli öğürgesinden girişmeli } \\
\text { ve ağa tahtasından kaplamalı ve } \\
\text { cidid kurşunlu ve elvan boya } \\
\text { tuğra saçak tecdîdi. }\end{array}$ & & 4 & 2 & & $\begin{array}{l}8 \times \mathrm{xi} \\
720= \\
5760\end{array}$ & saçak tecdîdi \\
\hline 32 & 3b & $\begin{array}{l}\text { Mahal-i mübârekede ceviz } \\
\text { çerçubeli ve yedi rubu' üzerine } \\
\text { tahta çam çerçube tecdîdi. }\end{array}$ & & 3 & 2 & & $\begin{array}{l}6 \times \mathrm{xi} \\
360=21 \\
60\end{array}$ & $\begin{array}{l}\text { çam çerçube } \\
\text { tecdîdi }\end{array}$ \\
\hline 33 & $\mathbf{3 b}$ & Mahal-i mübârekede sıva tecdîd. & & & & & $\begin{array}{l}105 \times \text { fi } \\
30=315 \\
0\end{array}$ & sıva tecdîd \\
\hline 34 & $\mathbf{3 b}$ & Kezalik bu mahalde badana. & & & & & $\begin{array}{l}105 \times \mathrm{fi} \\
4 \\
=420 \\
\end{array}$ & badana \\
\hline 35 & $\mathbf{3 b}$ & $\begin{array}{l}\text { Seyyidinâ Yakub aleyhisselam } \\
\text { Efendimizin zevcesi Sitti İlka } \\
\text { Validemizin } \\
\text { şeriflerinde sıva tecdîdi. }\end{array}$ & & & & & $\begin{array}{l}105 \times \text { fi } \\
30= \\
3150\end{array}$ & siva tecdîdi \\
\hline 36 & $\mathbf{3 b}$ & Bu mahal-i mübârekede badana. & & & & & $\begin{array}{l}105=42 \\
0\end{array}$ & badana \\
\hline 37 & $\mathbf{3 b}$ & $\begin{array}{l}\text { Bu mahal-i mübârekenin } \\
\text { kapılarına ve timur parmaklıklar } \\
\text { boya tecdîdi. }\end{array}$ & 3 & 3 & 1 & 18 & $\begin{array}{l}10 \\
\text { buçuk x } \\
\text { fi } 60 \\
=630\end{array}$ & boya tecdîdi \\
\hline 38 & $\mathbf{3 b}$ & $\begin{array}{l}\text { Mahal-i mübârekenin kapusuna } \\
\text {..... koğuşundan ve kilimli } \\
\text { çiftesinden kuşaklı ve pervazlı ve } \\
\text { neccarkari kapu. }\end{array}$ & 1 & 2,5 & 1,5 & & $\begin{array}{l}3 \text { buçuk } \\
=720\end{array}$ & $\begin{array}{l}\text { neccarkari } \\
\text { kapu }\end{array}$ \\
\hline 39 & $\mathbf{3 b}$ & $\begin{array}{l}\text { Merhum çeteci Abdullah Paşanın } \\
\text { imar eylediği kargir kubbelerin } \\
\text { sakfında mermer döşemesinde } \\
\text { derz. }\end{array}$ & & 14 & 5 & & $\begin{array}{l}70 \times \text { fi } \\
60= \\
4200\end{array}$ & $\begin{array}{l}\text { mermer } \\
\text { döşemesinde } \\
\text { derz }\end{array}$ \\
\hline 40 & $\mathbf{3 b}$ & $\begin{array}{l}\text { Bi'l-cümle kurşun } \\
\text { bârân hıfżlarıçün derz. }\end{array}$ & & & & & $\begin{array}{l}100 \times \mathrm{fi} \\
60=600\end{array}$ & $\begin{array}{l}\text { bârân hıfzı } \\
\text { içün derz }\end{array}$ \\
\hline 41 & $\mathbf{3 b}$ & $\begin{array}{l}\text { Mahal-i mübâreke minarelere } \\
\text { badana. }\end{array}$ & 2 & 15 & 16 & & $\begin{array}{l}480 \times \mathrm{fi} \\
30 \\
=14400 \\
\end{array}$ & badana \\
\hline 42 & $\mathbf{3 b}$ & $\begin{array}{llr}\text { Mahal-i } \quad \text { mübârekenin } & \text { sakfi } \\
\text { üzerinde } & \text { Karakolhanede } & \text { taşı } \\
\text { mevcud duvarı tecdîdi. } & \\
\end{array}$ & & 3 & 1,5 & & $\begin{array}{l}4 \text { buçuk } \\
\text { x fi } \\
240= \\
1080\end{array}$ & $\begin{array}{l}\text { duvarı } \\
\text { tecdîdi }\end{array}$ \\
\hline 43 & $\mathbf{3 b}$ & $\begin{array}{l}\text { Atik Cami-i şerifin ve Harem } \\
\text { Havlısı beyninde } \\
\text { kubbelerde badana. }\end{array}$ & & 46 & 8 & & $\begin{array}{l}368 \times \text { fi } \\
15= \\
5520\end{array}$ & $\begin{array}{l}\text { kubbelerde } \\
\text { badana }\end{array}$ \\
\hline
\end{tabular}




\begin{tabular}{|c|c|c|c|c|c|c|c|}
\hline 44 & $\mathbf{3 b}$ & $\begin{array}{l}\text { Mezkûr kubbeler üzerinde küllü } \\
\text { ve kireçli ve kalemkâri sıva } \\
\text { tecdîdi. }\end{array}$ & & 46 & 6 & $\begin{array}{l}299 \times \text { fi } \\
30= \\
8970\end{array}$ & siva tecdîdi \\
\hline 45 & 3b & $\begin{array}{l}\text { Atik Cami-i şerifin derûnunda } \\
\text { etraf dıvarlarında } 2 \text { kat sıva } \\
\text { tecdîdi. }\end{array}$ & & 68 & 14 & $\begin{array}{l}952 \times \text { fi } \\
30 \\
=28560\end{array}$ & siva tecdîdi \\
\hline 46 & $\mathbf{3 b}$ & $\begin{array}{l}\text { Yine Cami-i şerifin tekne } \\
\text { kubbelerinde iki kat sıva tecdîdi. }\end{array}$ & & 46 & 22 & $\begin{array}{l}1012 \times \\
\text { fi } 30 \\
=30360\end{array}$ & sıva tecdîdi \\
\hline 47 & $\mathbf{3 b}$ & $\begin{array}{l}\text { Bu mahal-i mübâreke zemininde } \\
\text { taşı mevcud kireçli döşeme } \\
\text { tamiri. }\end{array}$ & & 46 & 22 & $\begin{array}{l}1012 \times \\
\text { fi } 60= \\
60720\end{array}$ & $\begin{array}{l}\text { döşeme } \\
\text { tamiri }\end{array}$ \\
\hline 48 & $\mathbf{3 b}$ & $\begin{array}{l}\text { Bu mahalde Kesros koğuştan } \\
\text { Rumeli öğürgesinden kuşaklı ve } \\
\text { pervazlı kapu. }\end{array}$ & 1 & 2 & 3 & $6=720$ & $\begin{array}{l}\text { kuşaklı ve } \\
\text { pervazlı kapu }\end{array}$ \\
\hline 49 & $\mathbf{3 b}$ & $\begin{array}{l}\text { Kapu-i mezbûre kufl ve miftah } \\
\text { tecdîdi. }\end{array}$ & & & & $\begin{array}{l}\text { Adet } 1 . \\
480\end{array}$ & $\begin{array}{ll}\text { kufl } & \text { ve } \\
\text { miftah } & \\
\text { tecdîdi } & \end{array}$ \\
\hline 50 & 3b & $\begin{array}{l}\text { Bu mahal-i şerifin sakfında küllü } \\
\text { ve kireçli ve kalemkâri sıva } \\
\text { tecdîdi. }\end{array}$ & & 46 & 22 & $\begin{array}{l}1012 x \\
\text { fi } 30= \\
30360\end{array}$ & sıva tecdîdi \\
\hline 51 & $\mathbf{3 b}$ & $\begin{array}{l}\text { Seyyidinâ } \text { Süleyman Nebi } \\
\text { aleyhisselam bina eylediği } \\
\text { kargir dıvarda sıva tecdîdi. }\end{array}$ & & 40 & 20 & $\begin{array}{l}800 \times \text { fi } \\
20= \\
16000\end{array}$ & siva tecdîdi \\
\hline 52 & $\mathbf{3 b}$ & $\begin{array}{l}\text { Bu mahalde sakıf üzerinden } \\
\text { cereyan eden bârân suyu hıfzı } \\
\text { içün bir adet bölükte horasanlı ve } \\
\text { kireçli ve cilalı ve rağınlı sıva } \\
\text { tecdîdi. }\end{array}$ & & 5 & 5 & $\begin{array}{l}25 \times \mathrm{fi} \\
60= \\
1500\end{array}$ & siva tecdîdi \\
\hline 53 & $\mathbf{3 b}$ & $\begin{array}{l}\text { Makamât-1 şeriflerde imâret } \\
\text { kubbesi dıvarında ve kubbede iki } \\
\text { kat sıva tecdîdi. }\end{array}$ & & 12 & 19 & $\begin{array}{l}228 \times \text { fi } \\
30= \\
6840\end{array}$ & siva tecdîdi \\
\hline 54 & 3b & $\begin{array}{l}\text { İmâret-i mezkûrun sakfinda } \\
\text { kireçli ve küllü ve kalemkâri sıva } \\
\text { tecdîdi. }\end{array}$ & & 10 & 10 & $\begin{array}{l}100 \times \text { fi } \\
30= \\
3000\end{array}$ & sıva tecdîdi \\
\hline 55 & $\mathbf{3 b}$ & $\begin{array}{l}\text { Cami-i Atikde kavs beynlerinde } \\
\text { kilimli hissesinden necmiye } \\
\text { parmaklık tecdîdi. }\end{array}$ & & 25 & 2 & $\begin{array}{l}50 \times \mathrm{fi} \\
60= \\
3000\end{array}$ & $\begin{array}{l}\text { parmaklık } \\
\text { tecdîdi }\end{array}$ \\
\hline 56 & $\mathbf{3 b}$ & $\begin{array}{l}\text { Seyyidinâ Süleyman } \\
\text { aleyhisselam efendimizin kapusu } \\
\text {....sıva tecdîdi. }\end{array}$ & & 4 & 4 & $\begin{array}{l}16 \times \mathrm{fi} \\
20= \\
3200\end{array}$ & sıva tecdîdi \\
\hline 57 & $\mathbf{3 b}$ & $\begin{array}{l}\text { Harem-i şerifin kapusu üzerinde } \\
\text { kubbede sıva tecdîdi. }\end{array}$ & & 13 & 5,5 & $\begin{array}{l}58 \times \text { fi } \\
20= \\
1160\end{array}$ & siva tecdîdi \\
\hline 58 & $\mathbf{3 b}$ & Bu mahalde divarda derz. & & & & $\begin{array}{l}80 \times \mathrm{fi} \\
30= \\
2400\end{array}$ & divarda derz \\
\hline 59 & $\mathbf{3 b}$ & $\begin{array}{l}\text { Tariku'l-mâ-i mahallinde hazine } \\
\text { koğuşunda kilimli çiftesinden } \\
\text { kuşaklı. }\end{array}$ & 2 & 2,5 & 1,5 & $\begin{array}{l}3 \text { buçuk } \\
=720\end{array}$ & $\begin{array}{l}\text { kilimli } \\
\text { çiftesinden } \\
\text { kuşaklı }\end{array}$ \\
\hline 60 & 3b & $\begin{array}{l}\text { Harem-i şerifin ittisalinde } \\
\text { cephaneye muttasıl taşı mevcud } \\
\text { divar tecdîdi. }\end{array}$ & & 11,5 & 8 & $\begin{array}{l}92 \times \text { fi } \\
120= \\
11040\end{array}$ & dıvar tecdîdi \\
\hline 61 & 3b & $\begin{array}{l}\text { Bu mahalde bir bab odanın taşı } \\
\text { mevcud dıvar tecdîdi. }\end{array}$ & & 11,5 & 5,5 & $\begin{array}{l}63 \\
\text { buçuk x } \\
\text { fi } 120 \\
=7620 \\
\end{array}$ & dıvar tecdîdi \\
\hline \multicolumn{7}{|c|}{$\begin{array}{r}\text { Cem'an Yekün } 359254 \\
\text { 2993,5 kuruş } 34 \text { Para. }\end{array}$} & \\
\hline
\end{tabular}




\begin{tabular}{|c|c|c|c|c|c|c|c|c|}
\hline \multicolumn{8}{|c|}{$\begin{array}{c}\text { "Seyyidinâ Üzeyr Nebi Aleyhisselam Efendimizin Makam-ı Âlilerinin Keşif Defter-i } \\
\text { müfredâtıdır." }\end{array}$} & \multirow{2}{*}{ cedîd trabzan } \\
\hline 1 & $4 \mathbf{a}$ & 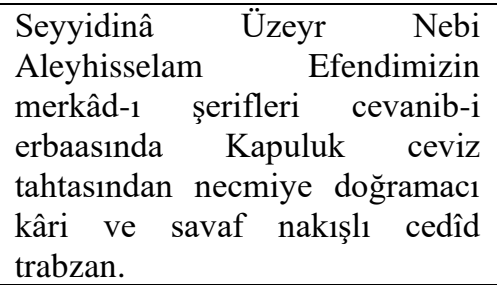 & & 17 & $\begin{array}{l}1,5 \\
\text { Kadden }\end{array}$ & & $\begin{array}{l}25 \\
\text { buçuk } x \\
\text { fi } \\
1200= \\
30720\end{array}$ & \\
\hline 2 & $4 \mathbf{a}$ & $\begin{array}{l}\text { Merkad-1 şerifin üzerine ketros } \\
\text { koğuşundan cedîd sanduka. }\end{array}$ & & 3,5 & 1 & & $\begin{array}{l}6 \times \text { fi } \\
120= \\
720\end{array}$ & cedîd sanduka \\
\hline 3 & $4 \mathbf{a}$ & $\begin{array}{l}\text { Bu mahal-i mübârekede Keşanlı } \\
\text { ve mermer açma enbeli ve } \\
\text { pervazlı mihrab tecdîdi. }\end{array}$ & & 3 & 3 & 14 & $\begin{array}{l}11 \\
\text { buçuk x } \\
\text { fi } 720= \\
8280\end{array}$ & $\begin{array}{l}\text { mihrab } \\
\text { tecdîdi }\end{array}$ \\
\hline 4 & $4 \mathbf{a}$ & Bu makamda sıva tecdîdi. & & 67 & $\begin{array}{l}15 \\
\text { Kadden }\end{array}$ & & $\begin{array}{l}1005 \times \\
\text { fi } 20= \\
20100\end{array}$ & sıva tecdîdi \\
\hline 5 & $4 \mathbf{a}$ & $\begin{array}{l}\text { Bu mahal-i mübâreke ceviz } \\
\text { çercubeli pirinçden tel örme } \\
\text { kafesli ve oda .....camlı pencere. }\end{array}$ & 3 & & & & $\begin{array}{l}3 \times 240 \\
=720\end{array}$ & camlı pencere \\
\hline 6 & $4 \mathbf{a}$ & $\begin{array}{l}\text { Mahal-i mübârekede sarı tekneli } \\
\text { ve kareli ve ketros koğuşundan } \\
\text { ve rezm ile öğ̈urgesinden kuşaklı } \\
\text { müceddeden kapu. }\end{array}$ & & 2 & 1 & 18 & $\begin{array}{l}\begin{array}{l}4 \\
=01800\end{array}\end{array}$ & $\begin{array}{l}\text { müceddeden } \\
\text { kapu }\end{array}$ \\
\hline 7 & $4 \mathbf{a}$ & $\begin{array}{l}\text { Kapu-i mezbûre çilingir kâri kufl } \\
\text { ve miftah. }\end{array}$ & & & & & $\begin{array}{l}1.600 \\
\text { kuruş }\end{array}$ & kufl ve miftah \\
\hline 8 & $4 \mathbf{a}$ & $\begin{array}{l}\text { Bu mahalde pirinç telden örmeli } \\
\text { ve gürgenden necmiye çercübeli } \\
\text { tel kafes tecdîdi. }\end{array}$ & & 3 & 2 & & $\begin{array}{l}7 \text { buçuk } \\
x \text { fi } \\
120= \\
900\end{array}$ & $\begin{array}{l}\text { tel kafes } \\
\text { tecdîdi }\end{array}$ \\
\hline 9 & $4 \mathbf{a}$ & $\begin{array}{l}\text { Makam-1 şerifin kavsı ve sıvası } \\
\text { tecdîdi. }\end{array}$ & & & & & $\begin{array}{l}7 \text { buçuk } \\
x \text { fi } \\
360= \\
2700\end{array}$ & sivası tecdîdi \\
\hline 10 & $4 \mathbf{a}$ & 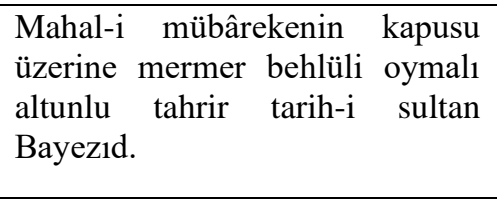 & & & & & $\begin{array}{l}1 \text { buçuk } \\
=1200\end{array}$ & $\begin{array}{l}\text { kapusu } \\
\text { üzerine } \\
\text { mermer } \\
\text { behlüli } \\
\text { oymalı } \\
\text { altunlu tahrir }\end{array}$ \\
\hline 11 & $4 a$ & 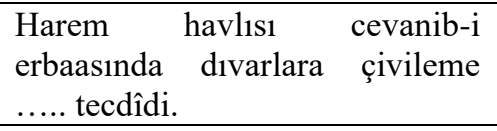 & & 71 & $\begin{array}{l}12 \\
\text { Kadden }\end{array}$ & & $\begin{array}{l}852 \times \text { fi } \\
20= \\
17040\end{array}$ & $? ?$ \\
\hline 12 & $4 \mathbf{a}$ & $\begin{array}{l}\text { Harem havlısına küfe taştan } \\
\text { döşeme tecdîdi. }\end{array}$ & & 20 & 18 & & $\begin{array}{l}360 \times \text { fi } \\
180= \\
64800\end{array}$ & $\begin{array}{l}\text { döşeme } \\
\text { tecdîdi }\end{array}$ \\
\hline 13 & $4 \mathbf{a}$ & $\begin{array}{l}\text { Harem havlısı vasatında } \\
\text { horasanlı ve kireçli ve rağınlı ve } \\
\text { cilalı bi'r-i ma. }\end{array}$ & 1 & 21 & 7 & & $\begin{array}{l}147 \times \text { fi } \\
60= \\
8820\end{array}$ & $\begin{array}{l}\text { cilalı bi'r-i } \\
\text { ma }\end{array}$ \\
\hline 14 & $4 \mathbf{a}$ & $\begin{array}{l}\text { Bu mahalde bir bab oda } \\
\text { derûnunda tecdîd sıva. }\end{array}$ & & & & & $\begin{array}{l}100 \times \mathrm{fi} \\
20= \\
2000\end{array}$ & tecdîd siva \\
\hline 15 & $4 \mathbf{a}$ & $\begin{array}{l}\text { Mahal-i merkumda hazine } \\
\text { koğuşuna labineli ve pervazlı ve } \\
\text { kuşaklı kapu. }\end{array}$ & 5 & 2,5 & 1 & 6 & $\begin{array}{l}15 \\
\text { buçuk } x \\
\text { fi } 120 \\
=1860 \\
\end{array}$ & $\begin{array}{l}\text { pervazlı ve } \\
\text { kuşaklı kapu }\end{array}$ \\
\hline 16 & $4 \mathbf{a}$ & $\begin{array}{lcr}\begin{array}{l}\text { Mahal-i mübârekenin } \\
\text { kapusu }\end{array} & \begin{array}{r}\text { sokak } \\
\text { ittisalinde } \\
\text { odasında tecdîd sıva. }\end{array}\end{array}$ & & & & & $\begin{array}{l}100 \times \mathrm{fi} \\
20=200 \\
0\end{array}$ & tecdîd siva \\
\hline 17 & $4 \mathbf{a}$ & Mezkûr havlım odası üzerine & & 7 & 6 & 15 & $255 \times \mathrm{fi}$ & müceddeden \\
\hline
\end{tabular}




\begin{tabular}{|c|c|c|c|c|c|c|c|c|}
\hline & & müceddeden bir bab oda. & & & & & $\begin{array}{l}480= \\
122400\end{array}$ & bir bab oda \\
\hline 18 & $\mathbf{4 a}$ & $\begin{array}{l}\mathrm{Bu} \text { mahalde on beş kademeli } \\
\text { nerdüban tecdîdi. }\end{array}$ & 15 & & 2 & & $6=1800$ & $\begin{array}{l}\text { nerdüban } \\
\text { tecdîdi }\end{array}$ \\
\hline 19 & $4 \mathbf{a}$ & $\begin{array}{l}\text { Cedîd odanın işlerinde kufeli } \\
\text { taşından döşeme tecdîdi. }\end{array}$ & & 6 & 2,5 & & $\begin{array}{l}16 \\
\text { buçuk x } \\
\text { fi } 180 \\
=2970\end{array}$ & $\begin{array}{l}\text { döşeme } \\
\text { tecdîdi }\end{array}$ \\
\hline 20 & $4 \mathbf{a}$ & $\begin{array}{l}\mathrm{Bu} \text { mahalde zokak kapusu } \\
\text { derûnunda çivileme derz. }\end{array}$ & & 15 & $\begin{array}{l}5 \\
\text { Kadden }\end{array}$ & & $\begin{array}{l}77 \\
\text { buçuk } x \\
\text { fi } \\
30=232 \\
5\end{array}$ & çivileme derz \\
\hline 21 & $4 \mathbf{a}$ & $\begin{array}{l}\text { Bu mahalde zokak kapusu } \\
\text { derûnunda etrafı divar çivileme } \\
\text { derz. }\end{array}$ & & & & & $\begin{array}{l}400 \times \mathrm{fi} \\
30 \\
=12000\end{array}$ & çivileme derz \\
\hline 22 & $4 \mathbf{a}$ & $\begin{array}{l}\text { Merkad ve makam-1 şerifin } \\
\text { üzerinde tecdîd divar. }\end{array}$ & & 13 & 8 & 18 & $\begin{array}{l}113 \\
\text { buçuk x } \\
\text { fi } 240 \\
=27280\end{array}$ & tecdîd dıvar \\
\hline 23 & $4 \mathbf{a}$ & $\begin{array}{l}\text { Seyyidinâ } \\
\text { efendimizn makam-1 şerifleri } \\
\text { sakfında kufeli taşından derzi } \\
\text { döşeme tecdîd. }\end{array}$ & & 19 & 11 & 18 & $\begin{array}{l}223 \times \mathrm{fi} \\
180 \\
=40185\end{array}$ & $\begin{array}{l}\text { derzi döşeme } \\
\text { tecdîd }\end{array}$ \\
\hline 24 & $\mathbf{4 a}$ & $\begin{array}{l}\text { Bu mahalde sakf üzerinde dört } \\
\text { üzerine kavisli ve kubbeli ve } \\
\text { timur kirişli alamet-i kubbe } \\
\text { tecdîdi. }\end{array}$ & & 3 & 3 & & $\begin{array}{l}45 \times \text { fi } \\
360= \\
16200\end{array}$ & kubbe tecdîdi \\
\hline 25 & $4 \mathbf{a}$ & $\begin{array}{l}\text { Cedîd odanın üzerine küllü ve } \\
\text { kireçli ve kalemkârî sıva tecdîdi. }\end{array}$ & & 9 & 7 & & $\begin{array}{l}63 \times \text { fi } \\
30= \\
1890\end{array}$ & siva tecdîdi \\
\hline 26 & $4 \mathbf{a}$ & $\begin{array}{l}\text { Oda-i merkumun ittisalinde } \\
\text { müsafir odasının sakfında kumlu } \\
\text { ve kireçli sıvacı kârî kalem } \\
\text { tecdîdi. }\end{array}$ & & 6 & 6 & & $\begin{array}{l}36 \times \mathrm{fi} \\
30= \\
1080\end{array}$ & $\begin{array}{l}\text { kârî kalem } \\
\text { tecdîdi }\end{array}$ \\
\hline 27 & $\mathbf{4 a}$ & $\begin{array}{l}\text { Alamet kubbesi mukabilinde } \\
\text { yine müsafir odası dıvarı hedm } \\
\text { ve taşı mahlut dıvar tecdîdi. }\end{array}$ & & 12 & $\begin{array}{l}5 \\
\text { Kadden }\end{array}$ & & $\begin{array}{l}60 \times \mathrm{fi} \\
120= \\
7200\end{array}$ & \\
\hline \multicolumn{9}{|c|}{$\begin{array}{r}\text { Cem'an Yekün } 399590 \\
\text { Kuruş } 3326 \text { buçuk kuruş } 50 \text { para } \\
\end{array}$} \\
\hline \multicolumn{9}{|c|}{ "Merkûm Haseki Sultan İmaretinin Keşif Defter-i Müfredâtıdır." } \\
\hline 1 & $4 \mathbf{b}$ & $\begin{array}{l}\text { İmaret-i mezkürenin furununda } \\
\text {... olunan iki tarafı kargir dıvar. }\end{array}$ & & 36 & 1,5 & & $\begin{array}{l}621 \times \text { fi } \\
120= \\
74520\end{array}$ & kargir divar \\
\hline 2 & 4b & $\begin{array}{l}\text { Bu mahalde oda ve kilerin kargir } \\
\text { dıvarı tecdîdi. }\end{array}$ & & 15 & 1,5 & & $\begin{array}{l}258 \\
\text { buçukx } \\
\text { fi } 120= \\
31020 \\
\end{array}$ & dıvarı tecdîdi \\
\hline 3 & $4 b$ & $\begin{array}{l}\text { Oda-i mezkürun nim kubbe } \\
\text { tecdîdi. }\end{array}$ & & 5,5 & 1,5 & & $\begin{array}{l}54 \times \text { fi } \\
360= \\
19440\end{array}$ & kubbe tecdîdi \\
\hline 4 & $4 b$ & Furun-1 mezkûrun kavsi tecdîdi. & & 12,5 & 1,5 & & $\begin{array}{l}183 \\
\text { buçuk } x \\
\text { fi } 300= \\
55050\end{array}$ & kavsi tecdîdi \\
\hline 5 & $4 b$ & $\begin{array}{l}\text { Bu mahalde taşı mevcud döşeme } \\
\text { sed divar tecdîdi. }\end{array}$ & & 8,5 & 2 & & $\begin{array}{l}17 \times \text { fi } \\
120= \\
2040\end{array}$ & dıvar tecdîdi \\
\hline 6 & $4 b$ & $\begin{array}{l}\text { Furun derûnunda sed dıvarı } \\
\text { tecdîdi. }\end{array}$ & & 10 & 1 & & $\begin{array}{l}10 \times \mathrm{fi} \\
120=\end{array}$ & dıvarı tecdîdi \\
\hline
\end{tabular}




\begin{tabular}{|c|c|c|c|c|c|c|c|}
\hline & & & & & & 1200 & \\
\hline 7 & 4b & $\begin{array}{l}\text { Furunu derûnunda derz ve tahtı } \\
\text { tozlu tamir-i fürun. }\end{array}$ & & & & $\begin{array}{l}4 \times \text { fi } \\
240= \\
960\end{array}$ & tamir-i fürun \\
\hline 8 & $4 \mathbf{b}$ & $\begin{array}{l}\text { Furun mahallinde divarlarında } \\
\text { sıva tecdîdi. }\end{array}$ & & & & $\begin{array}{l}20 \times \mathrm{fi} \\
30=600\end{array}$ & siva tecdîdi \\
\hline & & & & & & $\begin{array}{l}15 \times \text { fi } \\
30=450\end{array}$ & derz \\
\hline 9 & 4b & $\begin{array}{l}\text { Kilerde kargir dıvar tecdîdi. } \\
\text { Furun derûnunda sed dıvarı } \\
\text { tecdîdi. }\end{array}$ & & 7,5 & 1,5 & $\begin{array}{l}67 \\
\text { buçuk x } \\
\text { fi } 120= \\
8100\end{array}$ & dıvarı tecdîdi \\
\hline 10 & 4b & $\begin{array}{l}\text { Bu mahalde tekne kubbe tecdîdi. } \\
\text { Furun derûnunda sed divarı } \\
\text { tecdîdi. }\end{array}$ & & 7,5 & 1,5 & $\begin{array}{l}90 \times \mathrm{fi} \\
300= \\
27000\end{array}$ & dıvarı tecdîdi \\
\hline 11 & $4 \mathbf{b}$ & $\begin{array}{l}\text { Mahal-i mezkûrde } \\
\text { tahtasından ve kilimli çiftesinden } \\
\text { kuşaklı ve pervazlı ve şilteli } \\
\text { kapu. }\end{array}$ & 3 & $\begin{array}{l}2 \\
\text { Kadden }\end{array}$ & 1,5 & $\begin{array}{l}12 \times \text { fi } \\
600= \\
1800\end{array}$ & $\begin{array}{l}\text { pervazli ve } \\
\text { şilteli kapu }\end{array}$ \\
\hline 12 & $4 \mathbf{b}$ & $\begin{array}{l}\mathrm{Bu} \text { mahalde koğuş tahtasından } \\
\text { pencerelere ve kanatlar tecdîdi. }\end{array}$ & 12 & $\begin{array}{l}1,5 \\
\text { Kadden }\end{array}$ & 1 & $\begin{array}{l}18 \times \text { fi } \\
120= \\
2160\end{array}$ & $\begin{array}{l}\text { pencerelere } \\
\text { ve kanatlar } \\
\text { tecdîdi }\end{array}$ \\
\hline 13 & $4 \mathbf{b}$ & $\begin{array}{l}\text { Hınta Anbarında müceddeden } \\
\text { tekne kubbe. }\end{array}$ & 3 & 23 & 1,5 & $\begin{array}{l}621 \times \text { fi } \\
300= \\
186300\end{array}$ & $\begin{array}{l}\text { müceddeden } \\
\text { tekne kubbe }\end{array}$ \\
\hline 14 & $4 \mathbf{b}$ & $\begin{array}{l}\text { Anbar-1 mezkûrun derûnunda } \\
\text { kargir ayak tecdîdi. }\end{array}$ & 15 & 59 & 2 kadden & $\begin{array}{l}118 \times \text { fi } \\
120= \\
14160\end{array}$ & $\begin{array}{l}\text { kargir ayak } \\
\text { tecdîdi }\end{array}$ \\
\hline 15 & 4b & Bu mahalde bölme divar tecdîdi. & & 11 & 1 & $\begin{array}{l}49 \\
\text { buçuk } x \\
\text { fi } 130= \\
5940\end{array}$ & divar tecdîdi \\
\hline 16 & $4 b$ & $\begin{array}{l}\text { Bu mahalde taş rıhtımlı ve fevki } \\
\text { küllü ve kireçli sıvacı kârî kalem } \\
\text { tecdîdi. }\end{array}$ & & 18 & 16 & $\begin{array}{l}288 \times \text { fi } \\
60= \\
17280\end{array}$ & $\begin{array}{l}\text { kârî kalem } \\
\text { tecdîdi }\end{array}$ \\
\hline 17 & 4b & $\begin{array}{l}\text { Mizan Mahallinde kufeki taş } \\
\text { döşeme tecdîdi. }\end{array}$ & & 8 & 4 & $\begin{array}{l}32 \times \text { fi } \\
180= \\
5760\end{array}$ & $\begin{array}{l}\text { taş döşeme } \\
\text { tecdîdi }\end{array}$ \\
\hline 18 & $4 \mathbf{b}$ & 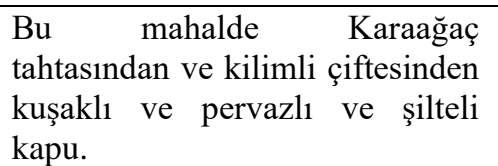 & 3 & $\begin{array}{l}2,5 \\
\text { Kadden }\end{array}$ & 1,5 & $\begin{array}{l}10 \\
\text { buçuk } x \\
\text { fi } 120= \\
1260\end{array}$ & $\begin{array}{l}\text { pervazlı ve } \\
\text { şilteli kapu }\end{array}$ \\
\hline 19 & $4 b$ & $\begin{array}{l}\text { Anbar-1 mezkûrun sakfında taş } \\
\text { rıhtımlı ve küllü ve kireçli sıvacı } \\
\text { kârî kalem tecdîdi. }\end{array}$ & & 23 & 18 & $\begin{array}{l}414 \times \text { fi } \\
60= \\
24840\end{array}$ & $\begin{array}{l}\text { kârî kalem } \\
\text { tecdîdi }\end{array}$ \\
\hline 20 & $4 b$ & $\begin{array}{l}\text { Anbar-1 merkumun tahtından } \\
\text { sakfına varınca on beş kademeli } \\
\text { ve etrafı dıvarlarında derz. }\end{array}$ & & & & $\begin{array}{l}60 \times \mathrm{x} \text { fi } \\
30= \\
1800\end{array}$ & derz \\
\hline 21 & $4 b$ & $\begin{array}{l}\text { Bu mahalde sed üzerine kireçli } \\
\text { ve küllü sıvacı kârî kalem } \\
\text { tecdîdi. }\end{array}$ & & & & $\begin{array}{l}28 \times \mathrm{fi} \\
30=840\end{array}$ & $\begin{array}{l}\text { kârî kalem } \\
\text { tecdîdi }\end{array}$ \\
\hline 22 & $4 b$ & $\begin{array}{l}\text { Matbah derûnunda iki ayakta } \\
\text { kireçli ve horasanlı ta'miri. }\end{array}$ & & & & $\begin{array}{l}32 \\
\text { buçuk } x \\
\text { fi } 20= \\
650\end{array}$ & ta'mir \\
\hline 23 & $4 b$ & $\begin{array}{l}\text { Bu mahalde kazkanlara koğuş } \\
\text { tahtasından kapak tecdîdi. }\end{array}$ & 3 & & & $\begin{array}{l}12 \times \text { fi } \\
120= \\
1440\end{array}$ & kapak tecdîdi \\
\hline 24 & $4 b$ & $\begin{array}{l}\text { Matbah-1 mezbûrun sakfında } \\
\text { küllü ve kireçli sıvacı kârî kalem } \\
\text { tecdîdi. }\end{array}$ & & 18 & 13 & $\begin{array}{l}234 \times \text { fi } \\
30= \\
7020\end{array}$ & $\begin{array}{l}\text { kârî kalem } \\
\text { tecdîdi }\end{array}$ \\
\hline 25 & $4 b$ & $\begin{array}{l}\text { Bu mahalde ocaklar etraflarında } \\
\text { küllü ve kireçli kalemkârî sıva }\end{array}$ & & 18 & 3 & $\begin{array}{l}54 \times \text { fi } \\
30= \\
1620\end{array}$ & $\begin{array}{l}\text { kalemkârî } \\
\text { siva tecdîdi }\end{array}$ \\
\hline
\end{tabular}




\begin{tabular}{|c|c|c|c|c|c|c|c|}
\hline & & tecdîdi & & & & & \\
\hline 26 & $4 b$ & $\begin{array}{l}\text { Değirmen sakfında kezalik küllü } \\
\text { ve kireçli sıvacı kârî kalem } \\
\text { tecdîdi. }\end{array}$ & & 16 & 14 & $\begin{array}{l}224 \times \text { fi } \\
30= \\
6720\end{array}$ & $\begin{array}{l}\text { kârî kalem } \\
\text { tecdîdi }\end{array}$ \\
\hline 27 & $4 b$ & $\begin{array}{l}\text { Bu mahalde küllü ve kireçli } \\
\text { sıvacı kârî kalem tecdîdi. }\end{array}$ & & 16 & 12 & $\begin{array}{l}192 \times \text { fi } \\
30= \\
5760\end{array}$ & $\begin{array}{l}\text { kârî kalem } \\
\text { tecdîdi }\end{array}$ \\
\hline 28 & $4 b$ & $\begin{array}{l}\text { İmaret-i mezbûrun derûnunda } \\
\text { merhum Sadeddin Rızası Türbesi } \\
\text { derûnunda sıva tecdîdi. }\end{array}$ & & 8 & 8 & $\begin{array}{l}64 \times \text { fi } \\
20= \\
1280\end{array}$ & sıva tecdîdi \\
\hline 29 & $4 b$ & $\begin{array}{l}\mathrm{Bu} \text { mahalde koğuş tahtasından } \\
\text { kapu tecdîdi. }\end{array}$ & 1 & $\begin{array}{l}3 \\
\text { Kadden }\end{array}$ & 2 & $6=720$ & kapu tecdîdi \\
\hline 30 & $4 b$ & $\begin{array}{l}\text { Merhum Sadeddin Rızası } \\
\text { üzerinde horasanlı ve kireçli ve } \\
\text { cilalı derz. }\end{array}$ & & $\begin{array}{l}16 \\
\text { Dûren }\end{array}$ & $\begin{array}{l}3 \\
\text { kadden }\end{array}$ & $\begin{array}{l}48 \times \text { fi } \\
30= \\
1440\end{array}$ & derz \\
\hline 31 & $4 b$ & $\begin{array}{l}\text { Buğday Anbarı mukabilinde } \\
\text { çivileme derz dıvar. }\end{array}$ & & 27 & $\begin{array}{l}12 \\
\text { kadden }\end{array}$ & $\begin{array}{l}324 \times \text { fi } \\
30= \\
9720\end{array}$ & derz divar \\
\hline 32 & $4 b$ & $\begin{array}{l}\text { Bu mahallin zokak kapusu } \\
\text { derûnunda tekne kubbede kireçli } \\
\text { siva tecdîdi. }\end{array}$ & & 6 & $\begin{array}{l}5 \\
\text { Dûren }\end{array}$ & $\begin{array}{l}30 \times \mathrm{fi} \\
30=900\end{array}$ & sıva tecdîdi \\
\hline 33 & $4 b$ & $\begin{array}{l}\text { Mahal-i mezbûrun zokak kapusu } \\
\text { ta'miri. } \\
\text { Terbi'an } 4 \text { x fi } 120=480\end{array}$ & & & & $\begin{array}{l}4 \times \mathrm{x} \text { fi } \\
120= \\
480\end{array}$ & $\begin{array}{l}\text { zokak kapusu } \\
\text { ta'miri }\end{array}$ \\
\hline \multicolumn{8}{|c|}{$\begin{array}{r}\text { Cem'an Yekün } 520270 \\
4335 \text { buçuk kuruș } 10 \text { para }\end{array}$} \\
\hline
\end{tabular}

“Seyyidinâ Davud Nebi Aleyhisselam Efendimizin Makam-ı Alilerinin Keşif Defter-i müfredâtıdır."

\begin{tabular}{|c|c|c|c|c|c|c|c|}
\hline 1 & $\begin{array}{l}4 \\
\text { b }\end{array}$ & 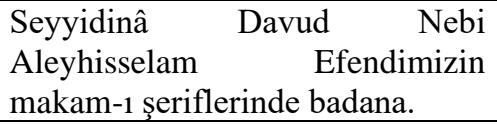 & & 20 & $\begin{array}{c}6 \\
\text { Dûren }\end{array}$ & $\begin{array}{l}120 \times \mathrm{fi} \\
4=480\end{array}$ & badana \\
\hline 2 & $\begin{array}{l}4 \\
\text { b }\end{array}$ & $\begin{array}{l}\text { Bu mahal-i mübâreke ketenli } \\
\text { kireçli beyaz sıva tecdîdi }\end{array}$ & & 29 & $\begin{array}{c}6 \\
\text { Dûren }\end{array}$ & $\begin{array}{l}174 \times \text { fi } \\
30= \\
3480\end{array}$ & Sıva tecdîdi \\
\hline 3 & $\begin{array}{l}4 \\
\text { b }\end{array}$ & $\begin{array}{l}\text { Sakf üzerinde nerdüban bâlâsında } \\
\text { hazine koğuşundan ve kilimli } \\
\text { çiftesinden kuşaklı kapu. }\end{array}$ & 1 & $\begin{array}{c}2,5 \\
\text { kadden }\end{array}$ & 2 & $5=600$ & kuşaklı kapu \\
\hline 4 & $\begin{array}{l}4 \\
\text { b }\end{array}$ & $\begin{array}{l}\text { Mahal-i mübârekenin üzerinde } \\
\text { küllü ve kireçli } \\
\text { ve kalemkârî sıva tecdîdi. }\end{array}$ & & 32 & 16 & $\begin{array}{l}512 \times \text { fi } \\
30= \\
15360\end{array}$ & sıva tecdîdi \\
\hline 5 & $\begin{array}{l}4 \\
\text { b }\end{array}$ & $\begin{array}{l}\text { Ziyaretci müsafír odası sakfında } \\
\text { küllü ve kireçli ve kalemkârî sıva } \\
\text { tecdîdi. }\end{array}$ & & 25 & 8 & $\begin{array}{l}200 \times \text { fi } \\
30= \\
1000\end{array}$ & siva tecdîdi \\
\hline 6 & $\begin{array}{l}4 \\
\text { b }\end{array}$ & Minarede sıva derz ta'mir. & & & & $\begin{array}{l}100 \quad x \\
60 \\
=6000 \\
\end{array}$ & $\begin{array}{ll}\text { Siva } & \text { derz } \\
\text { ta'mir } & \end{array}$ \\
\hline 7 & $\begin{array}{l}4 \\
\mathbf{b}\end{array}$ & $\begin{array}{llr}\text { Mahal-i } & \text { mübâreke } & \text { tekne } \\
\text { kubbesinde } & \text { cedîd kurşun } & \text { vazlı } \\
\text { elvah. } & & \end{array}$ & & & & $\begin{array}{l}29 . \\
\text { Beheri } \\
30 . \\
\text { Kiyye } \\
870 \times 6 \\
=5320 \\
\end{array}$ & $\begin{array}{l}\text { cedîd kurşun } \\
\text { vazlı elvah }\end{array}$ \\
\hline \multicolumn{8}{|c|}{$\begin{array}{r}\text { Cem'an Yekün } 37140 \\
309 \text { buçuk } \\
\end{array}$} \\
\hline \multicolumn{8}{|c|}{ "Seyyidinâ Musa Nebiyi Aleyhisselam Efendimizin Makam-ı Şeriflerinin Keşif Defter-i müfredâtıdır." } \\
\hline 1 & $5 \mathbf{a}$ & $\begin{array}{lrr}\text { Seyyidinâ } & \text { Musa } & \text { Nebiyi } \\
\text { Aleyhisselam } & \text { Efendimizin } \\
\text { Makam-1 âlilerinde harem havlısı }\end{array}$ & & 36 & 5,5 & $\begin{array}{l}98 \times \text { fi } \\
60= \\
11880\end{array}$ & tecdîdi sıva \\
\hline
\end{tabular}




\begin{tabular}{|c|c|c|c|c|c|c|c|c|}
\hline & & $\begin{array}{l}\text { vasatında kıble canibinde } \\
\text { horasanlı ve kireçli ve rağneli sıva } \\
\text { ve cilalı bi'r-ü'l-mâ tecdîdi sıva. }\end{array}$ & & & & & & \\
\hline 2 & $5 \mathbf{a}$ & $\begin{array}{l}\text { Bu mahal-i mübârekede horasanlı } \\
\text { ve kireçli ve rağneli ve cilalı bi'r- } \\
\text { ü'l-mâ derûnunda sıva tecdîdi. }\end{array}$ & 1 & 24 & 5,5 & & $\begin{array}{l}264 \times \text { fi } \\
60= \\
15840\end{array}$ & siva tecdîdi \\
\hline 3 & $5 \mathbf{a}$ & Tathir-i bi'ir ra'i. & & 12 & 12 & $\begin{array}{l}3 \\
\text { kadden }\end{array}$ & $\begin{array}{l}432 \times \text { fi } \\
30= \\
13020\end{array}$ & $\begin{array}{l}\text { Tathir-i bi'ir } \\
\text { ra'i }\end{array}$ \\
\hline 4 & $5 \mathbf{a}$ & $\begin{array}{l}\text { Harem-i şerif havlısında kufe } \\
\text { taşından mevcud döşemelerini } \\
\text { bazen mahallerinden kalkub ve } \\
\text { mahalline horasanlı ve kireçli } \\
\text { vaz'1 }\end{array}$ & & & & & $\begin{array}{l}150 \times \text { fi } \\
120= \\
18000\end{array}$ & döşeme vaz'1 \\
\hline 5 & $5 \mathbf{a}$ & $\begin{array}{l}\text { Canib-i şimalde hadim odası } \\
\text { kargir cenubesinde dıvarı hedm } \\
\text { ve tecdîdi. }\end{array}$ & & 7 & 3 & $\begin{array}{l}10 \\
\text { kadde } \\
\mathrm{n}\end{array}$ & $\begin{array}{l}210 \times \mathrm{fi} \\
60= \\
12600\end{array}$ & $\begin{array}{l}\text { dıvarı hedm } \\
\text { ve tecdîdi }\end{array}$ \\
\hline 6 & $5 \mathbf{a}$ & $\begin{array}{l}\text { Merkad-ı şerifin ve Cami-i şerifin } \\
\text { sakfında horasanlı ve kireçli derz. }\end{array}$ & & & & & $\begin{array}{l}150 \times \text { fi } \\
20= \\
3000\end{array}$ & derz \\
\hline 7 & $5 \mathbf{a}$ & $\begin{array}{l}\text { Bu mahalde fürunun kubbesi fena } \\
\text { bulmağla horasanlı ve kireçli derz } \\
\text { ve ta'mir. }\end{array}$ & & 2,5 & 2,5 & & $\begin{array}{l}6 \times \text { fi } \\
120= \\
720\end{array}$ & derz ve ta'mir \\
\hline 8 & $5 \mathbf{a}$ & $\begin{array}{l}\text { Mahal-i mübârekenin cevanib-i } \\
\text { erbaasında mevcud kargir } \\
\text { dıvarlarında çivileme derz. }\end{array}$ & & & & & $\begin{array}{l}260 \times \mathrm{fi} \\
20= \\
5200\end{array}$ & çivileme derz \\
\hline \multicolumn{9}{|c|}{$\begin{array}{r}\text { Cem'an Yekün } 80260 \\
668 \text { buçuk kuruș } 40 \text { para }\end{array}$} \\
\hline
\end{tabular}

"Seyyidinâ Yunus Nebiyi Aleyhisselam Efendimizin Makam-ı Şerifinin Keşif Defter-i müfredâtıdır."

\begin{tabular}{|c|c|c|c|c|c|c|}
\hline 1 & $5 a$ & $\begin{array}{l}\text { "Seyyidinâ Yunus Nebiyi } \\
\text { Aleyhisselam } \\
\text { Makam-1 şerifleri mihrabında ve } \\
\text { taşra kapu dıvarında sıva tecdîdi." }\end{array}$ & 11 & $\begin{array}{l}4 \\
\text { kadden }\end{array}$ & $\begin{array}{l}44 \times \text { fi } \\
20= \\
880\end{array}$ & siva tecdîdi \\
\hline 2 & $5 a$ & $\begin{array}{l}\text { Mahal-i mübârekede sakfın } \\
\text { üzerine küllü ve kireçli ve } \\
\text { kalemkârî sıva tecdîdi. }\end{array}$ & 34 & 16 & $\begin{array}{l}576 \times \text { fi } \\
30= \\
17280\end{array}$ & sıva tecdîdi \\
\hline 3 & $5 a$ & $\begin{array}{l}\text { Bu mahalde taşı mevcud dıvar } \\
\text { tecdîdi. }\end{array}$ & & & $\begin{array}{l}35 \times \text { fi } \\
60= \\
2100 \\
\end{array}$ & dıvar tecdîdi \\
\hline 4 & $5 a$ & $\begin{array}{l}\text { Bu mahal-i mübârekenin etraf } \\
\text { dıvarlarında çivileme derz tecdîdi. }\end{array}$ & & & $\begin{array}{l}75 \times \mathrm{fi} \\
30= \\
2250\end{array}$ & derz tecdîdi \\
\hline
\end{tabular}
187 buçuk kuruş 10 para

"Seyyidinâ İsa Nebiyi Aleyhisselam Efendimizin Makam-ı Şeriflerinin Keşif Defteridir."

\begin{tabular}{|l|l|l|l|l|l|l|l|l|}
\hline 1 & $\mathbf{5 a}$ & $\begin{array}{l}\text { Seyyidinâ İsa Nebiyi } \\
\text { Aleyhisselam } \\
\text { merkad-1 şeriflerinde sıva tecdîdi. }\end{array}$ & & 7 & 3,5 & $\begin{array}{l}18- \\
14\end{array}$ & $\begin{array}{l}434 \mathrm{x} \\
\text { fi } 20= \\
8680\end{array}$ & siva tecdîdi \\
\hline 2 & $\mathbf{5 a}$ & $\begin{array}{l}\text { Bu mahal-i mübârekede Tekne } \\
\text { kubbesinde siva tecdîdi. }\end{array}$ & 16 & $\begin{array}{l}10 \\
\text { dûren }\end{array}$ & $\begin{array}{l}160 \mathrm{x} \\
\text { fi } 20= \\
3200\end{array}$ & siva tecdîdi \\
\hline 3 & $\mathbf{5 a}$ & $\begin{array}{l}\text { Seyyidinâ Aleyhisselam } \\
\text { Efendimizin sandukasında siva } \\
\text { tecdîdi. }\end{array}$ & 5 & 1,5 & & $\begin{array}{l}22 \\
\text { buçuk } \\
\text { fi } 20 \\
=450\end{array}$ & siva tecdîdi \\
\hline 4 & $\mathbf{5 a}$ & Bu mahalde kubbelerde badana. & & & & & 200 & badana \\
\hline
\end{tabular}




\begin{tabular}{|c|c|c|c|c|c|c|}
\hline & & & & & $\begin{array}{l}\text { buçuk } \\
\text { x fif } 4= \\
800\end{array}$ & \\
\hline 5 & 5a & $\begin{array}{l}\text { Harem havlısı tahtında küllü ve } \\
\text { kireçli ve kalemkârî sıva tecdîdi. }\end{array}$ & 12 & 8 & $\begin{array}{l}96 \times \mathrm{xi} \\
30= \\
2880\end{array}$ & siva tecdîdi \\
\hline 6 & $5 \mathbf{a}$ & $\begin{array}{l}\text { Bu mahalde kufeli taşından } \\
\text { döşeme derzli tecdîd döşeme. }\end{array}$ & 8 & 8 & $\begin{array}{l}64 \times \mathrm{xfi} \\
30= \\
1920\end{array}$ & $\begin{array}{l}\text { derzli tecdîd } \\
\text { döşeme }\end{array}$ \\
\hline 7 & $5 \mathbf{5 a}$ & Bu mahalde sed divar tecdîdi. & & & $\begin{array}{l}8 \times \mathrm{xfi} \\
120= \\
960\end{array}$ & $\begin{array}{l}\text { sed divar } \\
\text { tecdîdi }\end{array}$ \\
\hline 8 & 5a & $\begin{array}{l}\text { Merkad-1 şerifin ve harem havlısı } \\
\text { üzerinde küllü ve kireçli ve sıvac1 } \\
\text { kâri kalem tecdîd ve sıva. }\end{array}$ & 19,5 & 18,5 & $\begin{array}{l}359 x \\
\text { fi } 30= \\
10770\end{array}$ & $\begin{array}{l}\text { kalem tecdîd } \\
\text { ve siva }\end{array}$ \\
\hline
\end{tabular}

"Seyyidinâ Eşmovil Nebiyi Aleyhisselam Efendimizin Makam-ı Mübârekesinin Keşif Defteridir."

\begin{tabular}{|c|c|c|c|c|c|c|}
\hline 1 & $5 \mathbf{a}$ & $\begin{array}{l}\text { Seyyidinâ Eşmovil Aleyhisselam } \\
\text { Efendimizin merkad-1 şerifleri } \\
\text { mahallinde ketenli ve kireçli } \\
\text { beyaz sıva tecdîdi. }\end{array}$ & 70 & 10 & $\begin{array}{l}700 x \\
\text { fi } 20= \\
14000\end{array}$ & siva tecdîdi \\
\hline 2 & $5 a$ & $\begin{array}{l}\text { Mahalli mübârekenin sakfinda } \\
\text { kumlu ve kireçli ve kalemkârî } \\
\text { sıva tecdîdi. }\end{array}$ & 16 & 10 & $\begin{array}{l}160 x \\
\text { fi } 30= \\
4800\end{array}$ & siva tecdîdi \\
\hline 3 & $5 a$ & $\begin{array}{l}\text { Bu Mahalde cami-i şerifin } \\
\text { sakfinda kumlu ve kireçli ve } \\
\text { kalemkârî sıva tecdîdi. }\end{array}$ & 37 & 18 & $\begin{array}{l}666 x \\
\text { fi } 20= \\
13320\end{array}$ & siva tecdîdi \\
\hline 4 & 5a & $\begin{array}{l}\text { Bu Mahalde birûnunda taşra } \\
\text { divara derz. }\end{array}$ & & & $\begin{array}{l}40 \times \mathrm{xfi} \\
20= \\
800\end{array}$ & $\begin{array}{l}\text { taşra divara } \\
\text { derz }\end{array}$ \\
\hline
\end{tabular}

“Gamame ittisalinde Hazreti Ömer r.a. anhu hazretlerinin Cami-i şerifin Keşif Defteridir.”

\begin{tabular}{|c|c|c|c|c|c|c|c|}
\hline 1 & $5 \mathbf{5 b}$ & 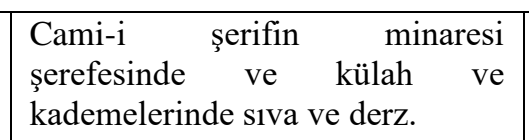 & & & & $\begin{array}{l}240 x \\
\text { fi } 30= \\
7200\end{array}$ & siva ve derz \\
\hline 2 & $5 b$ & $\begin{array}{l}\text { Cami-i şerifin derûnunda ketenli } \\
\text { ve kireçli beyaz sıva tecdîdi. }\end{array}$ & & 25 & $\begin{array}{l}5 \\
\text { kadden }\end{array}$ & $\begin{array}{l}125 x \\
\text { fi } 20= \\
2500\end{array}$ & sıva tecdîdi \\
\hline 3 & $5 \mathbf{5 b}$ & $\begin{array}{lcr}\text { Bu mahal-i } & \text { mübârekede } & \text { Ketros } \\
\text { koğuşundan } & \text { ve } & \text { Rumili } \\
\text { öğürgesinden } & \text { kuşaklı } & \text { ve } \\
\text {.....kufilli siva kapu tecdîdi. } & \end{array}$ & 2 & $\begin{array}{l}2,5 \\
\text { kadden }\end{array}$ & 1,5 & $\begin{array}{l}7= \\
1200\end{array}$ & $\begin{array}{l}\text { Siva kapu } \\
\text { tecdîdi }\end{array}$ \\
\hline \multicolumn{8}{|c|}{$\begin{array}{r}\text { Cem'an Yekün } 10900 \\
\text { Cem'an } 90 \text { buçuk kuruş } 40 \text { para }\end{array}$} \\
\hline & & $\begin{array}{l}\text { ld Şod: Der-sicilli mahfuz der-Mal } \\
\text { Irrire Heze'd-defter el-Keşf Nâfiz } \\
\text { akîr ileyhi 'azze şânuhû. } \\
\text { r-i mumaileyhin me'muriyeti ve key }\end{array}$ & & kudü & ilen & sani sen & $\begin{array}{l}195 . \\
\text { s-i Şerîf bi- } \\
\text { uhasebeden }\end{array}$ \\
\hline
\end{tabular}




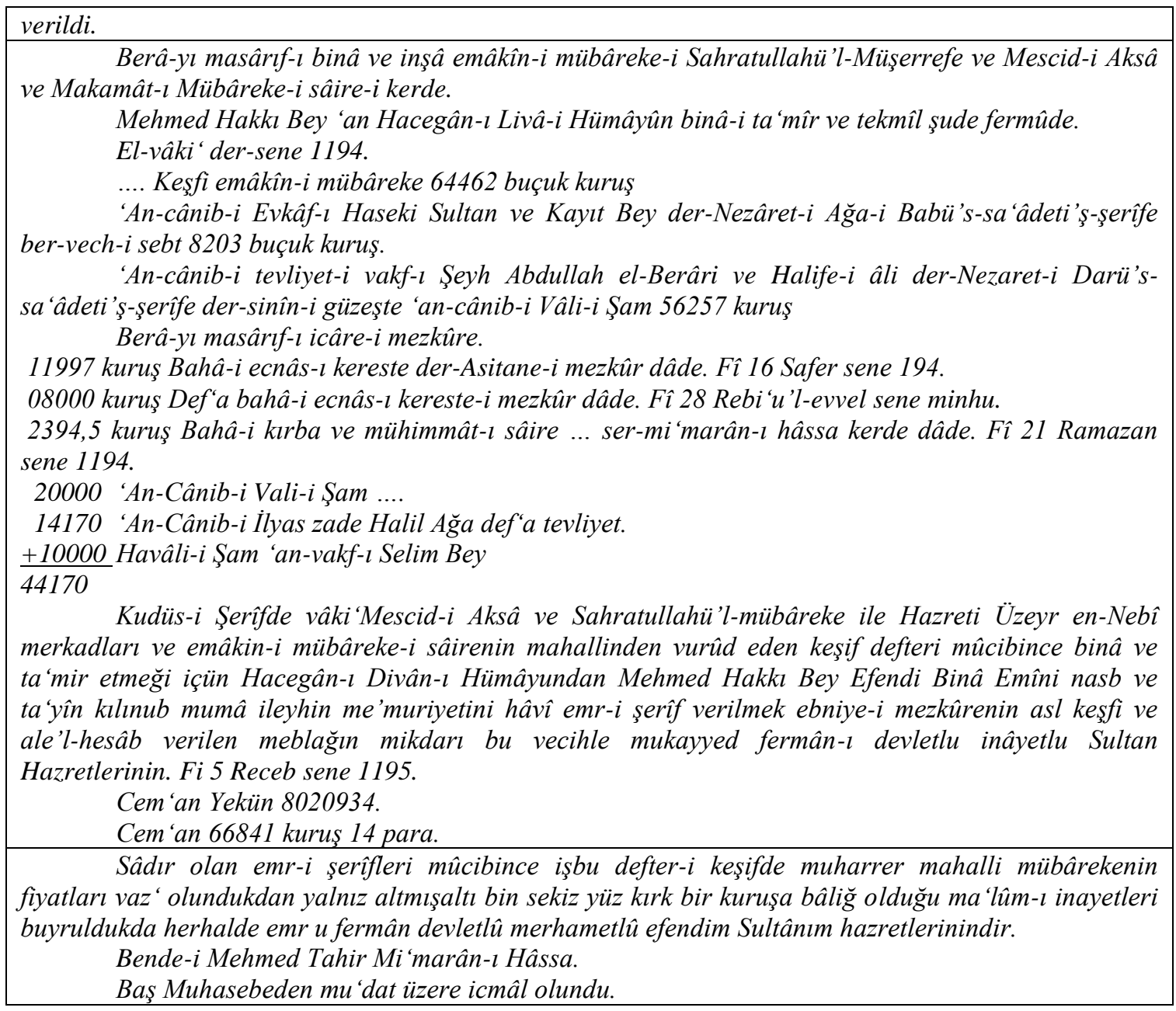

